\title{
A New Order of the Ages. Normativity and Precedence
}

\author{
Ulrike Müßig
}

\section{Contents}

1 Novus Ordo Seclorum ................................................................................................ 4

2 Definitions of Normativity and Precedence …….............................................................. 5

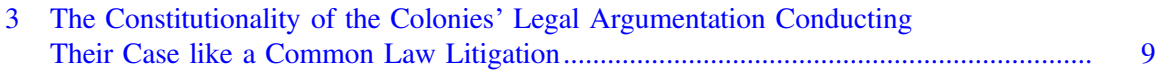

3.1 The British-American Discursive Common Law Community ................................ 11

3.2 Customary Old Liberties Against Parliamentary Absoluteness................................. 12

3.3 No Westminster Legislation on the Internal Colonial Polities.................................. 21

3.4 Self-reliance of the British Imperial 'Constitution' .................................................. 25

3.5 Legal Force of Custom in the Unsettled Connexion of the Colonies to Britain...... 30

4 Establishing Constitution as Law.............................................................................. 33

4.1 Emergence of the Constituent American People ........................................................ 33

4.2 Constitution as Supreme Legal Codex for Central State Issues .............................. 40

4.3 Farewell to the Lockean 'Inter legislatorem et populum nullus
in terris est judex' ................................................................................

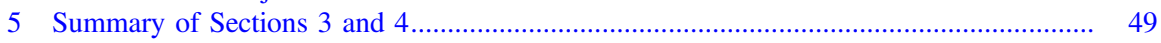

6 Legal Transition of Philosophical Truths ................................................................... 50

6.1 Sieyès' Constitutional Jury (jury constituionnaire)............................................... 52

6.2 Defeat of Sieyès' Jury Proposal and Its Consequences on the French

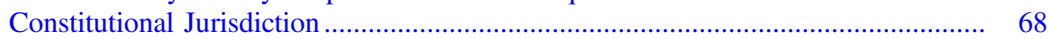

7 Avenues of New Constitutional Research: Sketching Germany, 1848-9........................ 71

7.1 Juridification Matters in the Public Sphere Around the Constituent St. Paul's Church Assembly..

7.2 Supremacy Matters in the Public Sphere Around the Constituent

St. Paul's Church Assembly.............................................................................. 76

7.3 Revision Matters in the Public Sphere Around the Constituent

St. Paul's Church Assembly.................................................................................. 81

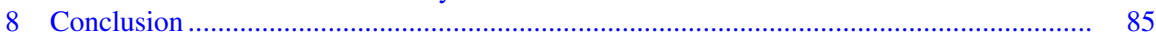

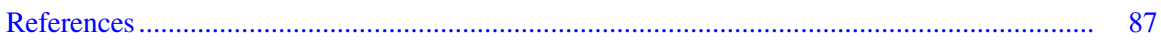

ERC Advanced Grantee (ReConFort)

U. Müßig (ه)

University of Passau, Passau, Germany

e-mail: Ulrike.Muessig@uni-passau.de

(C) The Author(s) 2018

U. Müßig (ed.), Reconsidering Constitutional Formation II Decisive Constitutional Normativity, Studies in the History of Law and Justice 12,

https://doi.org/10.1007/978-3-319-73037-0_1 
Abstract In the second research period of the Advanced Grant ReConFort (201617), precedence of constitution was the central interest for understanding historical constitutional discourses; these discussions have been further enriched by research into the Polish case study of 1815, which is also addressed in this volume. On the functional level as tertium comparationis, precedence of constitution guarantees the normativity of the modern constitutional concept, comprising the conceptual differentiation from ordinary law, the aggravated alterability (sometimes even up to an 'eternal' restriction on the constituent power) and the hierarchically supreme justiciability as legal tests for subordinate laws. Arising out of the American and French Revolution, the new normativity of the 'constitution', now connoted as a legal text, fixed the whole political order into one legal order. This claimed to be 'the basis and foundation of government', as the Virginia Declaration of Rights of 1776 starts, or 'Le but de toute institution politique', in the wording of the preamble of the French 1789 Declaration of the Rights of Man and Citizen. However, irrespective of the superficial linguistic commonalities, the revolutionary American and French discourses on constitutional precedence differ significantly, and met widely varying challenges. Nevertheless, both discourses provided the basic framework for European constitutional developments of decisive normativity in the late eighteenth and nineteenth century. Therefore, they act as cornerstones for comparative research on this key category, reconsidering constitutional formation between old liberties and new precedence. These foundations have guided not only the Principal Investigator's following essay, but also the papers of the ReConFort postdocs and the contributions of the speakers at the international Brussels conference, on 14 March 2016, which are combined in this volume.

In the case of America, colonist resistance against Westminster produced a written superior law set above all political power, due to the efforts to justify the revolution as a legitimate breach of common law. The colonies' legal argumentation conducted their case like a common-law litigation and borrowed from a long-standing constitutional semantic already traceable in early modern European monarchies. The subordination of ordinary legislative assemblies under fundamental laws (lois fondamentales) — as demonstrated in the granting of religious freedom to all inhabitants in the founding document of the Colony of West New Jersey (1676) - remained based on the traditional grounds that fundamental laws had a specific importance that elevated them above ordinary laws. Neither legal legitimation nor the binding of political authority by very important laws was a new or even revolutionary concept. The British-American discursive common law community was built around the prominence of the Magna Carta and the Bill of Rights, and it was indeed these fundamental laws on which the colonists relied for recalling their customary old liberties as subjects of the British king. Facing Westminster's unitarian legislative absoluteness in the imperial context, the colonists developed the differentiation between legal and constitutional; the Stamp Act and the Sugar Act, although legal, were argued to be unconstitutional due to the violation of common law liberties. A complementary legal argument was the distinction of the Empire from internal colonial polities, which were governed by the old liberties and privileges as English subjects and not by the superintending power 
of the British Parliament. In the unsettled connexion of the colonies to Britain, American lawyers relied on Coke's supremacy concept of common law as immortal custom, as it was understood through Blackstone's Commentaries. As long as the legal debate was kept on the customary level of their old rights as Englishmen, all questions of precedence were mere questions of the applicability of ordinary law. This changed with the natural law 'basis and foundation of government' expressed in the Virginia Bill of Rights, which itself was not vested with any superior rank, but was still analogous to common law.

The Declaration of Independence invoked a united American people, distinct from the British colonial power. Thereby emerging, the constituent American people became the reference point for establishing the constitution as law, as well as its revision and interpretation, though there were only the people of the thirteen individual states of the Union. Due to the lack of an unitarian state, the supremacy of the United States Constitution rested not only on it being the legal benchmark for all political powers to protect freedom and property, but also on it being the guarantee for the existence of the Union. Such an interlinkage between the Constitution and the Union invigorated the distinction between superior constitutional law and ordinary statutory law (also of the single federal states), and opened up the discourse on constitutional jurisdiction. In bidding farewell to the Lockean idea that there was 'no judge on earth between the legislative and the people', the secular 'judge' filled the gap between the legislative branch and the people, which had been caused by the legal separation of the Constitution from the ordinary legislation. The ordinary jurisdiction of the Supreme Court became authorised to measure the statutory law against the 'higher will of the people', meaning the Constitution. The Lockean right to resistance-addressed in his god-judge equivalence - was taken up by the federal jurisdiction. Marbury v. Madison (1803) accepted the latter's prerogative to examine statutory constitutionality or unconstitutionality in a 'judicial review.'

The common law tradition of the American idea of law was far removed from the French Rousseauist understanding of law as the expression of the volonté générale. Freedom by participation in legislation - articulated in Art. 6 Declaration of the Rights of Man and Citizen as (fraternal-political) equality (liberté, egalité, fraternité - - is and was totally unknown to the American constitutional discourse. Furthermore, 'Le but de toute institution politique' of the 1789 declaration reached for the same universal validity, but its philosophical wording only achieved the appropriate legal status by incorporation in the preamble of the September Constitution (1791). Whereas the American resistors differentiated constitutional law and ordinary law conceptually in their effort to justify the revolution as legitimate, the French discourse is, even now, very reluctant to review the unconstitutionality of acts of the legislative assembly, disregarding the difference between the ordinary legislative assembly and the constituent assembly (representing national sovereignty), following Sieyès' differentiation between constituent national sovereignty and constituted sovereignty. Even under the current French Constitution (enacted on 4 October 1958), there is no review of statutes for unconstitutionality except for the narrow scope of the 'prior question of constitutionality' (question 
prioritaire de constitutionnalité or QPC) dealing with the a posteriori control of promulgated statutes being compatible with the rights and liberties guaranteed by the constitution in Art. 61-1. The failure of Sieyès' draft of a 'jury constitutionnaire' in the Thermidorian debates of the year III (1795; reproduced here in the French original in Appendix A and in the English translation in Appendix B) was only the first link in a chain of reasoning to refuse any judicial authority to declare statutory law to be unconstitutional and overrule it. Sieyès planned for his jury to be staffed with former congressmen rather than professional judges. However, the Rousseauistic dogma of the general will and the continuous constituent power of the French people did not allow for Sieyès' project to open a window of opportunity for constitutional complaints to be addressed even by individual citizens in their own name to the constitutional jury. Together with the skepticism of the Constitutional Convention about the jury's resemblance to the judicial privileges of the Ancien Régime, this led to Sieyès' petition being rejected unanimously in the Constitutional Convention of the year III.

Finally, sketching matters of juridification, supremacy, and revision in the public sphere around the constituent St. Paul's Church Assembly underlines the interconnection not only between the discourses established in the above case studies (applied in a different context), but also between the key issues of the ReConFort project as a whole. In spite of the fact that it ultimately failed to come into force, the German Imperial Constitution of 1849 is a clear example that national sovereignty (Reconsidering Constitutional Formation I) marked the starting point for the process of juridification of sovereignty; constitutional precedence (Reconsidering Constitutional Formation II) was the legal tool to complete the process of juridification of sovereignty.

\section{Novus Ordo Seclorum}

The motto Novus Ordo Seclorum ('A new order of the ages'), appearing underneath the unfinished pyramid on the reverse side of the Great Seal of the United States, was coined in 1782 by Charles Thomson. He adapted it from Virgil's Eclogue IV, a pastoral poem of the first century BCE, where a Sibyl prophesied the fate of the Roman Empire in her longing for a new era of peace and happiness. ${ }^{1}$

\footnotetext{
${ }^{1}$ Translation (by James Rhoades): 'Now the last age by Cumae's Sibyl sung/Has come and gone, and the majestic roll/Of circling centuries begins anew: Justice returns, returns old Saturn's reign, With a new breed of men sent down from heaven. Only do thou, at the boy's birth in whom/The iron shall cease, the golden age arise. Under thy guidance, whatso tracks remain/Of our old wickedness, once done away/Shall free the earth from never-ceasing fear. He shall receive the life of gods, and see/Heroes with gods commingling, and himself/Be seen of them, and with his father's worth/Reign o'er a world at peace.' The oracle of Sybil refers to the Old Testament history, starting with Adam and Eve, of the reprehensibility of the (five) lineages before the Great Flood. After the Flood, the 'golden age', beginning with Noah, followed. Sibyl was part of this sixth lineage. People of this age stayed always healthy, did not age, and died peacefully. This was
} 
Charles Thomson (1729-1824) was the secretary of the Continental Congress; ${ }^{2}$ his name appeared on the first published version of the Declaration of Independence in July 1776 , alongside that of John Hancock, the congress' president. ${ }^{3}$ Thomson placed the motto beneath the unfinished pyramid, ${ }^{4}$ whose vacant peak stood for the lost monarchy after the renegade colonies have declared themselves independent on 4 July 1776. The pyramid and its motto, therefore, acted as the graphical depiction that marked 'the beginning of the new American Era', commencing from the Declaration of Independence.

\section{Definitions of Normativity and Precedence}

Normativity in modern constitutional $\operatorname{dogma}^{5}$ means the obligatory character of the constitution as a legal regime to control ${ }^{6}$ and to restrict state power. ${ }^{7}$ This amounts to the positivistic, compulsory, and justiciable nature of constitutional law, its

followed by the age of the titans. Cf. Die sibyllinischen Orakel, Die Aussprüche und Weissagungen der alten Sibylle über die Vergangenheit, Gegenwart und Zukunft der Welt, Aus alten Schriften in deutscher Übertragung mit Einleitung und erläuternden Anmerkungen, 2nd ed., ed. Richard Clemens (Wiesbaden: Fourier, 1985), 65-6, 80-1, 90-1. The idea of paradisiacal conditions in present time are the theme of Virgil's fourth Eclogue. The text describes a new golden era which begins with the birth of a mysterious boy. This age is characterised by the absence of misery, hassles, and the enjoyment of the fruits of the earth without the effort of the people - there being no need for agriculture, commerce, or seafaring. This utopia becomes concrete for Virgil with Augustus. See Töns (1977), 154-5. Cf. Ryberg (1958), 112-31. In the first two pages, Ryberg points out that the golden age was already addressed by Hesiod.

${ }^{2}$ Thomson served as the secretary of the Continental Congress from its founding in 1774 until its dissolution in 1789. His role was essentially to keep the minutes of the Congress, undertaking duties that nowadays are undertaken by the Department of State, the Secretariat of the Senate, and the Clerk of the House of Representatives. He was considered by his contemporaries to be an unimpeachable figure whose honesty was above reproach, and documents with his signature were considered 'the Truth.'

${ }^{3}$ Between the founding of the Continental Congress in 1774 and the enacting of the United States Constitution in 1789, there was no cameral differentiation of the executive and legislative branches; the Congress occupied both. It also voted for the 'President of Congress', as the office of the President of the United States obviously did not exist at the time.

${ }^{4}$ The designer of the pyramid in 1782, including the Eye of Providence motif, was a lawyer named William Barton. He, in turn, was probably influenced by Francis Hopkinson's pyramid design on the $\$ 50$ Continental Currency banknote (1778); Hopkinson had also been consulted in 1780 on the heraldic design for the Great Seal. For the final design of the reverse side of the Great Seal, Charles Thomson specified 'A Pyramide unfinished'. He put a triangle around the eye of Providence, as suggested by the first committee.

${ }^{5}$ Cf. for the Parliamentary Council (Parlamentarischer Rat) Badura (1973), 19-20, 23.

${ }^{6}$ Loewenstein (1975), 127.

${ }^{7}$ Badura (1973), 19, 22; Friedrich (1953), 135. Cf. Starck (1992), § 164 Recital 1. Unless otherwise noted, all translations are those of the author. 
differentiation from and hierarchical precedence over ordinary law ${ }^{8}$ and, moreover, its aggravated alterability. ${ }^{9}$ In the specific provisions of the German Basic Law (Articles 1 section 3, 20 section 3, 79 section 3) ${ }^{10}$ the so-called 'eternity clause' in Article 79 section 3 restrains even the constituent power.

Reconsidering constitutional formation, one should be very aware that it is the normativity which is the novelty of the modern constitutional concept arisen out of the American and the French Revolutions at the end of the eighteenth century. Neither governmental legitimisation nor legal binding of political authority were new terms, but rather had long been part of the old constitutional semantics. ${ }^{11}$ Also, the subordination of legislative assemblies - as in the founding document of the Colony of West New Jersey $(1676)^{12}$-remains on the traditional ground of the specific importance of fundamental laws (lois fondamentales) that were higherranking than ordinary laws. ${ }^{13}$ In the case of America, it was the break with the English mother country that required a new legal fixture of the (whole) political order. 'Constitution' was now connoted as a legal text, fixing the political order into a legal order. This provided, according to the opening sentence of the Virginia Declaration of Rights of 12 June 1776, 'the basis and foundation of government., 14

\footnotetext{
${ }^{8}$ Cf. Kastari (1966), 49-50, 52.

${ }^{9}$ Badura (1992a), § 159 Recital 1. The term normativity thus describes two different aspects of the constitution: in a narrow sense, normativity refers to the positivistic mandatory effect of the constitution as a legal rule, as described in Badura (1992b), vol. VII, § 160 Recital 2; in a broader sense, normativity is a comprehensive term for the specific legal effects of the constitution.

${ }^{10}$ For the coherence between Articles 1 (3), 20 (3), 79 (3) cf. Dreier (2007), 3-4, 53-4. Dreier does not differentiate between the mandatory effect and the precedence of the constitution.

${ }^{11}$ For details cf. Müßig (2006b), 1-2.

${ }^{12} \mathrm{~A}$ dissociation between ordinary and higher-ranking laws already emerged rudimentarily during the colonial era, especially within the framework of the founding document of the Colony of West New Jersey from 1676 ('Concessions and Agreements'). A particular part of this founding document, agreed upon in 1677 under the title 'The Charter or Fundamental Laws, of West New Jersey' clearly articulates the subordination of the legislative assembly under these fundamental articles and states the prohibition to pass laws which contradict these fundamental articles. Cited in Stourzh (2015), 58. Cf. also Fundamental Laws and Constitutions of New Jersey 1664-1961, ed. Boyd (1964), 13.

${ }^{13} \mathrm{Cf}$. fundamental work on the terms lex fundamentalis, lois fondamentales, and constitution: Mohnhaupt and Grimm (2002), 38-9, 48, 62-3; Mohnhaupt (2016), "Leges fundamentals", column 693-695; Gough (1961); Mohnhaupt (1982), 3-33; Mohnhaupt (1998), 121-158; Mohnhaupt (2011), 697-724.

14،A DECLARATION OF RIGHTS made by the representatives of the good people of Virginia, assembled in full and free convention which rights do pertain to them and their posterity, as the basis and foundation of government.' Compare le but de toute institution politique in the wording of the preamble of the Declaration of the Rights of Man and Citizen of 1789: Willoweit and Seif (=Müßig) (2003), 250.
} 
Normativity is expressed by the positivation in one unified constitutional text. The textual 'seclusiveness' stands for the differentiation between constitutional law and ordinary legislature. The old constitutional semantics knew particularly important, fundamental laws, ${ }^{15}$ but not the idea of a unified law, which is a gauge for the legitimacy of all other laws. As James Iredell phrased it in his 'Instructions to Chowan County Representatives' (1783), this was to be a 'Republic where the Law is superior to any or all the Individuals, and the Constitution superior even to the legislature, and of which the judges are guardians and protectors. ${ }^{, 16}$

The central consequence of normativity is the supremacy of the constitution, its precedence. With the American Revolution, constitutional law and other kinds of law were conceptually differentiated, contrary to English terminology. ${ }^{17}$ For the English legal minds, such as Lord Bolingbroke $(1678-1751)^{18}$ or William Blackstone (1723-80), ${ }^{19}$ there was an equivalence between the constitution (or frame) of government and the system of laws. ${ }^{20}$ These theorists and practitioners neither distinguished between fundamental and statutory law, nor measured the latter against the first. By 1776, the American resistance against Westminster produced the notion of a constitution 'as a written superior law set above the entire government against which all other law is to be measured." ${ }^{21}$ The context for this was the American effort to justify the revolution as legitimate breach of law. ${ }^{22}$

\footnotetext{
${ }^{15}$ To their priority by 'advice and approval of the most influential': Ulrike Seif, "Einleitung", in Willoweit and Seif (2003), xii ff.

${ }^{16}$ The Papers of James Iredell, ed. Higginbotham (1976), vol. II, 449.

${ }^{17}$ Wood (1969), 260. In 1789, France adopted the English word constitution, with all its blurring of constitutional discussion, and then only discussed the extent of the division of power that had become necessary. See also Stern (1984), 9.

${ }^{18}$ For details, his commitment to the treaty of Utrecht and his literary treatment in the 'Idea of a Patriot King' (1738), cf. Müßig (2008c), 16-17.

${ }^{19}$ Cf. Müßig (2008c), 18-19.

${ }^{20}$ Cf. Blackstone, William (1979), Commentaries on the Laws of England, vol. I, 126; Bolingbroke, Henry St. John (1749), The idea of a patriot king, 84 (universal law of reason, given immediately to all men by god vs. particular law, or constitution of laws, given to man by man); Bolingbroke, Henry St. John (1754), A Dissertation upon parties, 141-2 in regard to the distinction between government and constitution: 'By constitution we mean [...] the assemblage of laws, institutions and customs, derived from certain fix'd objects of public good, that compose the general system, according to which the community hath agreed to be govern'd [...] By government we mean $[\ldots]$ that particular tenor of conduct, which a chief magistrate, and inferior magistrates, under his direction and influence, hold in the administration of public affairs.'

${ }^{21}$ Wood (1969), 260.

${ }^{22}$ Müßig (2006b), 4.
} 
The taxation of the colonies by the Westminster Parliament without the consent of the inhabitants, as embodied in the Sugar Act (American Revenue Act/American Duties Act) of $1764^{23}$ and the Stamp Act (Duties in American Colonies Act) of $1765,{ }^{24}$ was 'unconstitutional', while the resistance of the colonies was, it was argued by those same resistors, "constitutional. ${ }^{25}$ In the context of the eighteenth-century British discourse "the terms constitutional and unconstitutional, mean legal and illegal', as it was explained by William Paley in The Principles of Moral and Political Philosophy (Philadelphia 1788). It was exactly on this aspect that the Americans diverged from the English terminology. As John Adams ${ }^{26}$ articulated in 1773 - even before the American Revolutionary War had begun, and three years prior to the Declaration of Independence - the principal difficulty in the debate with England lay in the 'different ideas [about] the words legally and constitutionally', ${ }^{27}$ and in the shift of Westminster from the highest common court to the sovereign lawmaker. This leads us to the analysis of the legal argumentation of the American colonies, and how they conducted their case like a common law litigation in the court of Anglophone public opinion. ${ }^{28}$

\footnotetext{
${ }^{23}$ American Duties Act of 29 September 1764, in 4 George III, c. 15. The revenue-raising act, passed by the Westminster Parliament on 5 April 1764, stated in its preamble: 'it is expedient that new provisions and regulations should be established for improving the revenue of this Kingdom $[\ldots]$ and $[\ldots]$ it is just and necessary that a revenue should be raised $[\ldots]$ for defraying the expenses of defending, protecting, and securing the same.' A significant section of the colonial economy during the Seven Years' War dealt with supplying food and supplies to the British Army. Therefore, it is often said that the protests against the Sugar Act were motivated more by economic needs rather than by the constitutional issue of taxation without representation.

${ }^{24}$ Duties in American Colonies Act of 22 March 1765, in 5 George III, c. 12.

${ }^{25}$ 'Therefore the terms constitutional and unconstitutional mean legal and illegal.' Paley (1825), 372. See also Stourzh (1988), 35, 45ff.; Wood (1969), 10ff., 261.

${ }^{26}$ John Adams (1735-1826): Graduating from Harvard University in 1755, Adams was a lawyer in Suffolk County, Massachusetts. As opponent to the Stamp Act he later, in 1768, represented the city of Boston in the General Court. Growing increasingly prominent in legal and political circles, Adams became a congressman at the Continental Congress, and served between 1774 and 1777, and was also a signatory to the Declaration of Independence. His first diplomatic appointment was as the American minister plenipotentiary to Holland in 1782; three years later, he was appointed as the American representative at the Court of St. James. He served in this capacity until 1789, when he became the United States' first vice president, under George Washington. In 1797, he stood for president and won the election, and served as the second president of the United States until 1801. Cf. Dodge and Koed (2005), 542-3; Encyclopædia Britannica (2007) Founding Fathers, 16-25.

${ }^{27}$ Adams, John, letter to the Boston Gazette (8 February 1773), in The Works of John Adams (1851), vol. III, 556.

${ }^{28}$ Greene (2010), 186.
} 


\title{
3 The Constitutionality of the Colonies' Legal Argumentation Conducting Their Case like a Common Law Litigation
}

\author{
The colonial lawyers, such as Richard Bland, ${ }^{29}$ James Otis, ${ }^{30}$ Daniel Dulany, ${ }^{31}$ \\ John Dickinson, ${ }^{32}$ James Wilson, ${ }^{33}$ Thomas Jefferson, ${ }^{34}$ John Adams, Alexander
}

\footnotetext{
${ }^{29}$ Richard Bland (1710-76): A cousin of Thomas Jefferson, Bland was born in Orange County, Virginia. Bland studied at the College of William and Mary, as well as the University of Edinburgh. For over three decades (1742-75) he represented Prince George County in the Virginia House of Burgesses, and was a member of several committees. This made him a logical delegate to the first and second Continental Congresses (1774-5), following which he took part in the Virginia Conventions, which opposed continued British rule. Pate (1931), 20.

${ }^{30}$ James Otis (1725-83): Like Adams a Harvard-trained lawyer, James Otis worked first in Plymouth before relocating to Boston. In 1761, he gave a speech in the writs of assistance case, which can be considered the prologue to the American Revolution. Writs of assistance gave the bearer (usually a British customs or excise official) carte blanche to search any premises for contraband. American colonists saw this as a dangerous instrument that could be used by officials to further personal agendas. Otis argued that they were unconstitutional; John Adams, who had watched Otis' oration, credited this moment as being the birthplace of 'the Child Independence.' Later, Otis was elected to the lower House of the General Court of Massachusetts. Huitt (1953-4), 152-3.

${ }^{31}$ Daniel Dulany (1722-97): Born in Maryland, Dulany studied at Eton College and Clare Hall, Cambridge University. He passed the bar in England in 1742, in Maryland in 1747. From 1751 to 1754 he was a representative in the House of the Maryland Legislative Assembly. From these beginnings he assumed a number of important positions, including Secretary of the Province (1761-74). He opposed the imposition of the Stamp Act; nevertheless, he remained a loyalist to the Crown during the American Revolution, the result of which was the confiscation of his property by American authorities in 1781. Riggs (1946), 8-15.

${ }^{32}$ John Dickinson (1732-1808): Dickinson studied law in London and practiced in Philadelphia. He represented Delaware in the Stamp Act Congress (1765). He was a delegate for Pennsylvania in the Continental Congress (1774-6), and was re-elected to the Congress in 1779. He prepared among others the Articles of Confederation, though he voted against the Declaration of Independence, as he believed reconciliation with Britain was still possible. In 1781 he became the president of Delaware, and from 1782-5 the president of Pennsylvania. He signed the United States Constitution as a delegate from Delaware. Gummere (1956), 81-8; Encyclopædia Britannica (2007) Founding Fathers, 72.

${ }^{33}$ James Wilson (1742-98): Wilson attended the Universities of St. Andrews, Glasgow, and Edinburgh, and emigrated to America in 1765. He studied law and was admitted to the bar in 1767; from 1778 he practiced in Philadelphia. In 1774, he became a member of the Provincial Convention of Pennsylvania, and was an intermittent member of the Continental Congress. He represented Pennsylvania at the Constitutional Convention (1787) and was a signatory to the Constitution. Biographical Directory of the United States Congress, 2180.

${ }^{34}$ Thomas Jefferson (1743-1826): A defining and vital figure in early American constitutionalism and federalism, Thomas Jefferson began work as a lawyer in 1767. Two years later, he became a member of the Virginia House of Burgesses, a position he relinquished in 1775 to join the Continental Congress. He was the primary author of and signatory to the Declaration of Independence. Thereafter he served as governor of Virginia (1779-81) and again as a congressman (1783-4), before being appointed minister of plenipotentiary to France (1784) and sole minister to
} 
Hamilton, ${ }^{35}$ Charles Carroll of Carrollton, ${ }^{36}$ and James Iredell ${ }^{37}$ seemed to 'conduct their case like a common-law litigation in the court of Anglophone public opinion. ${ }^{38}$ Other lay leaders, merchants, printers and planters, including Stephen Hopkins, ${ }^{39}$ Benjamin Franklin, ${ }^{40}$

the King of France (1785). These appointments lasted five years; upon his return he served as George Washington's secretary of state until 1793. In 1797 he became John Adams' vice president; in 1801 he was elected as the third president of the United States, and served two terms until 1809. Biographical Directory of the United States Congress, 1326-7; Encyclopædia Britannica (2007) Founding Fathers, 115-137.

${ }^{35}$ Alexander Hamilton (1755 or 1757-1804): Hamilton emigrated to America in 1772, where he received his education, and entered the Continental Army as a captain of the artillery in 1776 . He was a member of the Continental Congress in 1782, 1783, and 1788, and of the New York State Assembly in 1787. He was a member of the Philadelphia Constitutional Convention which adopted the Constitution, and he also took part in the Ratification Convention of 1788. Together with James Madison and John Jay, Hamilton wrote the series of essays known as The Federalist, which formed the basis of all modern interpretations of the Constitution. From 1789 until 1795 he was secretary of the Treasury in the cabinet of George Washington. In 1804, he took part in a duel with Vice President Aaron Burr. Burr was victorious, and Hamilton was mortally wounded. Biographical Directory of the United States Congress, 1182; Encyclopædia Britannica (2007) Founding Fathers, 96-105.

${ }^{36}$ Charles Carroll of Carrollton (1737-1832): The third in a line of Charles Carrolls (the others being Charles Carroll the Settler and Charles Carroll of Annapolis), Carroll was born in Maryland, and studied law in both France and England. He returned to Maryland in 1765, and in 1775 became a delegate to the Convention of Maryland. The next year, he joined the Continental Congress, which he served until 1778. He was re-elected in 1780 but declined the appointment. He was a state senator for Maryland from 1777 until 1800, and a United States senator between 1789 and 1792. A signatory to the Declaration of Independence in 1776, he was also the last surviving of the original Founding Fathers when he died in 1832. Biographical Directory of the United States Congress, 790.

${ }^{37}$ James Iredell (1751-99): A native of Sussex, England, Iredell migrated to America at seventeen years old, where he studied law. At twenty-six, he was appointed as a judge and, in 1779, he became the attorney general. He campaigned for the acceptance of the United States Constitution in North Carolina and, in 1790, he was nominated by Washington to an associate judgeship in the Supreme Court. Connor (1912), 225-53.

${ }^{38}$ Greene (2010), 186.

${ }^{39}$ Stephen Hopkins (1707-85): Raised on a farm on Rhode Island, Hopkins was descended from a line of important local political figures, including the first governor of Rhode Island, Benedict Arnold. Hopkins, too, followed this path, becoming a member of the Rhode Island General Assembly (1732-52; 1770-75). From 1751-54 and once more in 1773, he was the chief justice of the Superior Court of Rhode Island, and he also served as governor for four non-consecutive periods between 1755 and 1768. As a member of the Continental Congress from 1774 to 6 , he was also a signatory to the Declaration of Independence. Biographical Directory of the United States Congress, 1277; Encyclopædia Britannica (2007) Founding Fathers, 110.

${ }^{40}$ Benjamin Franklin (1706-90): Franklin first made his name as a printer and publisher in Philadelphia, after having learnt the trade in Boston, Philadelphia, and London. He bought the Pennsylvania Gazette in 1729. From 1736 to 1750, he was clerk of the Pennsylvania General Assembly. He held several public offices in the following years. From 1775 to 1776 he was a member of the Continental Congress and he signed the Declaration of Independence. Afterwards he became diplomatic commissioner to France and later minister to France from 1776 to 1785. Biographical Directory of the United States Congress, 1081; Encyclopædia Britannica (2007) Founding Fathers, 77-91. 
Samuel Adams, ${ }^{41}$ William Hicks, and William Henry Drayton, ${ }^{42}$ showed such a substantive familiarity with the common law reasoning and constitutional thought that one could think of a discursive community between both sides of the Atlantic.

\subsection{The British-American Discursive Common Law Community}

Key to this common law community was the familiarity with the same textbooks. English and American lawyers alike learned from Blackstone's Commentaries on the Laws of England (1765-9), ${ }^{43}$ whose American edition (1771-2) was the only legal textbook in the colonies en route to independence. ${ }^{44}$ The reception of Blackstone in James Kent's Commentaries on American Law (1826) demonstrated his great significance for the American understanding of the common law; indeed, it was the Blackstone commentaries that inspired the American constitutional fathers to conceive of the American president as a temporary, substitute monarch, founded after the ideal of the English king. Blackstone's conception of the 'Rights of Englishmen' as 'Rights of Mankind' is said to be an inspiration for the demand for universal human rights in the American Revolution. ${ }^{45} \mathrm{He}$ is also called a mentor for the strong judiciary in the American constitution of $1787 .^{46}$

\footnotetext{
${ }^{41}$ Samuel Adams (1722-1803): A descendent of Puritan migrants, Samuel Adams showed a keen mind for politics. He entered Harvard at the age of fourteen and eventually achieved a Masters degree; upon leaving his studies, however, he became a maltster and tax collector. From 1765 to 1774 he was a member of the Massachusetts General Court and from 1774 to 1781 a member of the Continental Congress. He was a signer of the Declaration of Independence. In 1781 he served as the president of the Massachusetts State Senate and from 1794 to 1797 he was governor of Massachusetts. Biographical Directory of the United States Congress, 543.

${ }^{42}$ William Henry Drayton (1742-79): Drayton studied in England and returned to South Carolina in 1764, where he studied law and was admitted to the bar. In 1770, on the order of King George III, he was appointed privy councillor of South Carolina and shortly thereafter assistant judge. After taking actions in the revolutionary movement, he was removed from both positions. In 1775 he served as president of the Council of Safety and in 1776 as chief of justice. In 1778 he was made a member of the Continental Congress, a position he held until his untimely death from typhus in the following year. Biographical Directory of the United States Congress, 892.

${ }^{43}$ Seif (=Müßig) (2008), "Blackstone, William”, column 614.

${ }^{44}$ Seif (=Müßig) (2008), "Blackstone, William", column 616.

${ }^{45}$ The first chapter of the first volume of Blackstone's Commentaries categorises the principal absolute rights as those of security, liberty, and property. Blackstone, William (1979), Commentaries on the Laws of England, vol. I, chap. 1, 119ff. See also Hanbury (1950), 318ff.; Lucas (1963), 142ff. These documents show the influence of Locke's conception of a general natural law that binds all government to heed security, liberty, and property of the individual.

${ }^{46}$ Carrese (2003), 117.
} 
Blackstone's well-known comment on parliamentary sovereignty ${ }^{47}$ is based on Sir Edward Coke's seventeenth-century definition of the supreme jurisdiction of the High Court of Parliament:

Of the power and jurisdiction of the parliament, for making of laws in proceeding by bill, it is so transcendent and absolute, as it cannot be confined either for causes or persons within any bounds. Of this court it is truly said: Si antiquitatem spectes, est vetustissima, si dignitatem, est honoratissima, si jurisdictionem, est capacissima. ${ }^{48}$

Irrespective of this court conception, Blackstone required for Great Britain as an empire with colonies, 'a supreme, irresistible, absolute uncontrolled authority, in which the jura summi imperii, or the rights of sovereignty reside[d] ${ }^{\text {,49 }}$ and, as the contemporary Agent for the Province of the Massachusetts Bay in London would have added, 'to which all other Powers should be subordinate[d]. ${ }^{50}$ This unitarian legislative supremacy in the imperial context was a logical violation of defining Parliament's sovereignty on the basis of the court's conception, and deprived the British discourse of any possibility to differentiate between legal and constitutional. This was exactly the legal point at which the colonists had to leave the motherland. They pleaded to be the 'better Englishmen', on the basis of the customary limitations for Westminster's supremacy in the imperial constitution, which they started to distinguish from the ordinary law.

\subsection{Customary Old Liberties Against Parliamentary Absoluteness}

The first legal point of the colonists was the differentiation between 'legal' and 'constitutional.' They argued that acts of Parliament, although legal, were against their ancient liberties under the common law and therefore unconstitutional. Faced with the Stamp Act and the Sugar Act, it became obvious in the colonies that Westminster 'Parliament [...] was no longer simply the highest court among others in the land, but had in truth become the sovereign law-maker of the realm, whose power, however arbitrary and unreasonable, was uncontrollable. ${ }^{51}$ What the

\footnotetext{
${ }^{47}$ Blackstone, William (1979), Commentaries on the Laws of England, vol. I, chap. 2, 156. Blackstone literally repeated Coke's definition.

${ }^{48}$ Coke, "The Fourth Part of the Institutes of the Laws of England concerning the Jurisdiction of Courts" in Coke, Edward (1797), The Institutes of the Law of England, Second to Fourth Parts, Part IV, 36.

${ }^{49}$ Blackstone, William (1979), Commentaries on the Laws of England, vol. I, 50-1, 178-80.

${ }^{50}$ Mauduit, Jasper (1766), Legislative Authority of the British Parliament, 11. Mauduit was the agent in London for the Province of the Massachusetts Bay between 1762 and 1765.

${ }^{51}$ Cited in Wood (1969), 265. Cf. also the differentiation between judgment and statutes in the preceding sentence: 'that law was something more than a judgment, more than simply the acts of a supreme court that could be interpreted, adjusted, or voided by other courts when required by the principles of reason and equity that supposedly adhered in all law.'
} 
colonists risked losing was the supremacy of common law, established by Sir Edward Coke since the seventeenth century. 'His' supremacy of common law translated the inherent customary consensus on liberties since time immemorial into legal arguments against the Stuart absolutism ${ }^{52}$; This common law understanding was present at Westminster in the Whig differentiation between ordinary legislation and the fundamental laws of nature, ${ }^{53}$ benefitting from the theories of natural law expounded by John Locke in his Second Treatise (1689), ${ }^{54}$ and Thomas Rutherforth in his Institutes of Natural Law (1754-6). The fundamental laws of nature were held by the latter 'to bind the legislative body itself, and not to be alterable by its authority. ${ }^{55}$ Whereas Rutherforth's statement saw Westminster as subject to the fundamental laws of nature, which seemed suitably straightforward for the colonists' legal argumentation, it was the Lockean natural 'Law antecedent and paramount to all positive Laws of men ${ }^{, 56}$ that lay at the heart of the sovereignty of the British Parliament. In the constitutional struggles against the absolutism of the Stuart dynasty, it provided Westminster with the authority of the last word on public good (publick good; common wealth), ${ }^{57}$ which could not be left to the

\footnotetext{
${ }^{52}$ Müßig (2009), 174-81.

${ }^{53}$ This was explicitly established by the former attorney general and chief justice of common pleas, Lord Camden, in two speeches he gave in the House of Lords on 2 February and 7 March 1766: 'Deriving either "from the Law of Reason and of Nature" or "from [the] Custom and Usage [of] our own Constitution," fundamental law consisted of those "public laws" that "prescribe[d] the form, and establish[ed] the constitutional power of the legislative body of the society." Cit. in Greene (2010), 95. Both speeches (the first one dates on 2 instead of 6 February) are also compiled in Proceedings and Debates of the British Parliaments respecting North America, 1754-1776, ed. Simmons and Thomas (1983), vol. II, 125f. (via report in the proceedings of 3 February), 147. ${ }^{54}$ Müßig (2014), “Locke, John”, columns 1029-32.

${ }^{55}$ Rutherforth (1862), chap. VI (Of Civil Laws), section XX (General division of civil laws), 399. Rutherforth's Institutes was one of the most widely cited legal references among the founding generation of the United States.

${ }^{56}$ Locke, John (1963), Second Treatise of Government, chap. XIV, § 168, 397-8.

${ }^{57}$ Locke, John (1963), Second Treatise of Government, chap. XIV, § 168, 397-8: 'The old Question will be asked in this matter of Prerogative, "But who shall be Judge when this Power is made a right use of?" I answer: Between an Executive in being, with such a Prerogative, and a Legislative that depends upon his will for their convening, there can be no Judge on Earth [...] the people have no other remedy in this, as in all other cases where have no judge on Earth, but to appeal to heaven [...] And therefore, tho' the People cannot be Judge, so as to have by the Constitution of that Society any Superiour power, to determine and give effective Sentence in the case; yet they have, by a Law antecedent and paramount to all positive Laws of men, reserv'd that ultimate Determination to themselves, which belongs to all Mankind, where there lies no Appeal on Earth, viz. to judges whether they have just Cause to make their Appeal to Heaven.' If the monarch was free to decide upon the public good alone, any restraints the law places on the execution of prerogative rights would be useless; the monarch would be absolute sovereign in regard to the connection between Coke's doctrine of common law based on reason and Locke's postulate of an antecedent natural law. Cf. in detail Seif (=Müßig) (2003b), 110-40.
} 
monarch's discretion. ${ }^{58}$ The common law background of the Lockean precepts gave significant persuasive weight to the colonial contention that Westminster had no jurisdiction over internal colonial affairs, as well as that the British king had ceased to be king for the colonies. ${ }^{59}$ Indeed, the omnipotent reason of the common lawits reason-based supremacy - was the godfather of the American limitation of any state power by the state goal to protect property in the sense of life, liberty, and possession. ${ }^{60}$ John Phillip Reid explicitly held the "American argument [was] similar to the old Whig case against Charles I and James II, except now the supremacy of parliament, not the royal prerogative, was the issue. ${ }^{61}$ While the British understanding of the unwritten British constitution puts the sovereign parliament at the core, the colonial comprehension of the British complex of statutes, common-law judicial precedents, particular documents having constitutional status (such as the famous Magna Carta of 1215), and constitutional conventions for the structure of government, was a restraint on arbitrary power. The threat of arbitrariness could emanate from any centre of power, be it the throne, the House of Lords, or the House of Commons. Therefore, in the American 'reading' of the unwritten British constitution, arbitrary power could also be vested in Parliament. If Parliament legislated for the colonies without a check or balance to call it to account, it ran into danger to act arbitrarily as the Sugar Act and Stamp Act proved.

\subsubsection{American Sympathies for the Supremacy of Common Law}

According to Sir Edward Coke, the specific historical legitimisation of common law, amounting to its supreme quality, is based on its age, since it is said to date back to the Norman Conquest (1066). This idea, however, did not originate with Coke. The equation of 'old law' as 'good law' was well established for the common law since the fifteenth century and its overall roots date back to 'antiquity'. As John Fortescue wrote:

[T] he realm has been continuously regulated by the same custom as it is now, customs which, if they had not been the best, some of those kings would have changed for the sake of justice or by the impulse of caprice, and totally abolished them. [No other laws] are so

\footnotetext{
${ }^{58}$ In the Declaration of the Houses in Defence of the Militia Ordinance of 6 June 1642, Parliament claimed the ultimate authority to decide on the public good. Likewise, the Nineteen Propositions of 1 June 1642 expressly stated 'that the great affairs of the kingdom, [held as] matters as concern the public, $[\ldots]$ are proper for the High Court of Parliament, which is your Majesty's great and supreme council.' Cited in The Constitutional Documents, ed. Gardiner (1906), no. 53, 250-1. Cf. also Locke, John (1963), Second Treatise of Government, chap. XIV, § 159, 392.

${ }^{59}$ Müßig (2014), "Locke, John”, columns 1029-32.

${ }^{60}$ Locke, John (1963), Second Treatise of Government, § 123ff. Cantor (1997); Hostettler (1997); Stoner (1992). Cf. also Seif (=Müßig) (2008a), "Coke, Edward", column 871-5 for further references.

${ }^{61}$ Reid (1974), 1067.
} 
rooted in antiquity. Hence there is no gainsaying nor legitimate doubt but that the customs of the English are not only good but the best. ${ }^{62}$

This praise of the English law to which Fortescue's oeuvre owes its name, In Praise of the Laws of England (about 1470), deems the proof of the quality of the common law to reside in its unaltered usage since the oldest ages, since time immemorial. The continuous general custom legitimised the unwritten common law: 'because it is given to all in common it is called common law. And for that there is no other law than this, it exists as one from of old, and in general councils or parliament it is suffered to be observed. ${ }^{, 63}$ According to Christopher St. German, the general custom was a universal consensus: 'the common law proper was divers general customs of old time used through all the realm, which have been accepted and approved by our sovereign lord the King and his progenitors and all their subjects. ${ }^{, 64}$

On the other hand, the common law was the purview of lawyers, unknown beyond the realms of the London Inns of Court. ${ }^{65}$ How can a law, based on the technicalities of writs and developed by and for the knowledge of a legal elite, be traced back to the consensus of the people? Nobody, after all, is born as a lawyer. ${ }^{66}$ How could common law lawyers explain that the customary law respected by the judiciary could bind the nation as a whole? This could only be achieved by the judicial consent faking the popular consent. The 'collective mind of the profession' thus subsumed and adopted the mantle of authority customarily represented by popular consent. ${ }^{67}$ In this way, artificial reason replaced general custom, more as an interpretative authority ${ }^{68}$ rather than as legislative consensus. ${ }^{69}$

\footnotetext{
${ }^{62}$ Fortescue (1997), chap. XVII, 26-7.

${ }^{63}$ Horne (1893), 5. Cf. also Doe (1990), 26; Lieberman (1989), 72.

${ }^{64}$ St. German (1974), 45. Prior to Blackstone, St. German's Doctor and Student (1528) was the primary English legal textbook, with the 'dialogue' of the title being a discussion of the role of equity.

${ }^{65}$ 'The general customs were the strength and warrant of maximes, which were unknown outside the Inns of Court.' St. German (1974), 59. Cf. also Guy (1985), 20-1; Stein (1966), 10.

${ }^{66}$ '[T] he common law itselfe is nothing else but reason; which is to be understood of an artificiall perfection of reason, gotten by long study, observation, and experience, and not of every man's naturall reason; for Nemo nascitur artifex.' Coke, Edward (1794), The First Part of the Institutes of the Laws of England, 97b.

${ }^{67}$ Finch (1759), 52-3. Cf. also Dodderidge (1631), 103; Prest (1977), 326-7. Further, the assessments of the British legal history: Doe (1990), 26; Ives (1983), 161.

${ }^{68}$ The authority of the general custom for the common law, however, is not negated. Cf. explicitly Coke, Edward (1826), The Reports, Ninth Reports 75b $=77$ ER 843 (Combes's Case).

${ }^{69}$ Coke, Edward (1826), The Reports, Second Reports 81a = 76 ER 597 (Lord Cromwel's Case); Coke, Edward (1826), The Reports, Sixth Reports (Sir John Molyn's Case).
} 
The foundation for this reasoned concept of the common law was established by Sir Edward Coke in his Reports (1600-15) ${ }^{70}$ and his quadripartite Institutes of the Laws of England (1628-44). ${ }^{71}$ The reasonableness of the common law was the battle cry of the common law lawyers against Stuart absolutism. ${ }^{72}$ It governed the arguments against the prerogative courts and against the royal prerogative. For instance, as the chief justice of the Common Pleas Court between 1606 and 1613, and of the King's Bench Division between 1613 and 1616, Coke made use of this argumentation to establish the supremacy of the jurisdiction of the common law over the monarch in the writs of prohibition and the case law, namely the Prohibitions del Roy (1607), the Case of Proclamations (1611) and the Case of the Five Knights (1627).

Just as his equation of custom with lawfulness was not new, neither was Coke's association of law and reason. As early as Cicero, it had been argued that 'law is the perfection of reason, which lies within the human nature. ${ }^{73}$ The synonymy of law and reason therefore marked the medieval Christian state theory by mediation of the scholasticism; law was, according to Thomas Aquinas, 'nothing else than a certain order of reason for the common wealth, promulgated by the responsible for the community. ${ }^{74}$ The reason conception of common law, however, was less based on the political philosophical theory but more on the linguistic congruency. It was already in the earliest case law journals (the so-called year books from the thirteenth century onwards $)^{75}$ that Latin-ancient-French legal terminology of Norman origin ${ }^{76}$ proves the linguistic equation of the law $(l e y=l a w)$ and reason $(\text { reason, resoun })^{77}$ : 'ley est resoun ${ }^{78}$; 'le ley est fond de reason, et ceo que est reason est ley ${ }^{, 79}$; '[d]onq comon reason, quiest comon ley ${ }^{80}$; 'carriens deins le monde parle si

\footnotetext{
${ }^{70}$ John Hamilton Baker, "Coke's Note-Books and the Sources of his Reports", in Baker (1986), 183, 186-7. It is only the Reports $1-11$ that Coke edited himself; Reports 12 and 13 were published posthumously. Here, the standard edition of the English Reports 1900-1932 (ER 76, 77) is used.

${ }^{71}$ Coke's Second Part (1642) contains a commentary to the Magna Carta and other medieval laws. Coke's Fourth Part (1644) depicts the different jurisdictions of England. As books of authority, they have the nature of legal sources; both parts justify the precedence of common law and the sovereignty of Parliament as highest court of law.

${ }^{72}$ Gray (1980), 25-6; (1992), 85-121; Lewis (1968), 330-1.

${ }^{73}$ Cicero (1959), De legibus, I, v, 19, 316.

${ }^{74}$ Aquinas, Thomas (1892), Summa theologiae, $\mathrm{I}^{\mathrm{a}}$-II ${ }^{\mathrm{ae}}$, quaestio XC, Arg. 4, 152.

${ }^{75}$ The year books (late thirteenth century till 1535 ) were replaced by personal decision compilations, such as Coke's Reports. In 1865, the semi-official redaction entity Incorporated Council of Law Reporting was introduced, which published the Law Reports. These exist today as the standard compilation of the All England Law Reports.

${ }^{76}$ Van Caenegem (1987), 114-15; Pollock and Maitland (1952), 79-80.

${ }^{77}$ Middle English Dictionary (reason): reison, seyson, resun, resoun, reson, raison, reason. Cf. also Baker (1979), 176. Ley = law is not to be equated with loi.

${ }^{78} 18$ \& 19 Ed. III (RS), 379 per Stonore J.

${ }^{79} \mathrm{~T} 14 \mathrm{Hen}$. VI, 19, 60 at 21 per Vampage.

${ }^{80} \mathrm{H} 35$ Hen. VI, 52, 17 at 53 per Fortescue CJKB.
} 
reasonablement come le ley parle.' 81 Occasionally, 'reason' and 'justice' appear synonymously. For instance, the medieval travel report Mandeville's Travels from the fourteenth century demonstrates justice in England through the reasonable and equal treatment of the poor and the rich: 'in that ile also er wonder rightwise iuggez, for they do resoun and trewth to like men, als wele to pouer as to riche. ${ }^{82}$ Reginald Pecock describes the law of England as reasonable law in The Folower to the Donet (ca. 1453): 'And as for the lawe of the kyng of englond, what is iugid bi iugis agens such constreyners, al is taken to be lawe of resoun, which thei callen her common lawe. ${ }^{83}$

When viewed together with common law, 'reason' not only means rationality of the highest degree (ratio summa), but also the intellectual method of the common law lawyers. ${ }^{84}$ 'Reason' is the capability acquired by means of legal training to develop legal rules out of the formless ${ }^{85}$ entirety of the legal knowledge since time immemorial. This was achieved in an inductive manner, handed down through year books and reports of preceding lawyers since the thirteenth century. This is demonstrated by Coke's terminology of 'artificial reason', ${ }^{86}$ which found its way into the Prohibitions del Roy (1607). ${ }^{87}$ Like an artist, the lawyer exercises his legal capabilities. The reasonableness of the law is perceived as its character; nobody could be legally knowledgeable if he had not understood that first: 'The reason of the law is the life of the law, for though a man can tell the law, yet if he knows not the reason thereof, he shall soon forget his superficial knowledge.' In the first part of his Institutes of the Laws of England, Coke adds to this the need for sustainable professionality. The reason of the law is nothing to be understood in passing: 'But when he findeth the right reason of the law, and so bringeth it to his natural reason, that he comprehendeth it as his own, this will not only serve him for the understanding of that particular case, but also many others, for cognitio legis est copulata et complicata, and this knowledge will long remain with him.' ${ }^{88}$ 'Artificial reason'

\footnotetext{
${ }^{81}$ P 13 Hen. VII, 22, 9 at 23 per Fineux CJKB. Cf. further examples at Müßig (2009), 177.

${ }^{82}$ Mandeville (1932), 141, line 24.

${ }^{83}$ Pecock (1924), 143. Cf. Green (1945), 12-13.

${ }^{84}$ Dodderidge (1631), 242; Finch (1759), 52; Noy, William (1641), A Treatise of the Principal Grounds and Maxims of the Laws of this Kingdom, 1, cited in accordance with Burgess (1992), 40. Cf. also Sommerville (1986), 92-3.

${ }^{85}$ Lambarde, William (1619), Eirenarcha, 511.

${ }^{86}$ The adjective is derived from artifex (lat.: artist) and signified the product of an artist, rather than 'synthetically man-made.'

87، ... are not to be decided by natural reason but by artificial reason and judgment of law, which law is an act which requires long study and experience, before that a man can attain to the cognizance of it.' Prohibitions del Roy (1607 = Mich. 5 Jacobi 1) 12 Co.Rep. $64=77$ ER 1342 1343 per Edward Coke, C.J.

${ }^{88}$ Coke, Edward (1794), The First Part of the Institutes of the Law of England, 183b. See also Coke, Edward (1794), The First Part of the Institutes of the Laws of England, 394b: 'ratio est anima legis, for then we are said to know the law when we apprehend the reason of the law, that is when we bring the reason of the law so to our own reason, that we perfectly understand it for our own.'
} 
is the collective knowledge of the common law judges and Coke seems to allude to the scholastic interconnection of human and divine ratio by Thomas Aquinas: 'ratio est radius divini luminis.' The metaphorical contrast between the 'darkness of ignorance' and the 'light of legal reason' super-elevates legal training 'by reasoning and debating of grave learned men ${ }^{89}$ as ratio legis, and cements thereby the monopoly of interpretation for the learned lawyers and their superiority over the legally untrained monarch: 'and thereupon judgement is given according to the law, which is the perfection of reason. ${ }^{90}$ This legitimation of the common law by means of judicial reasonableness ${ }^{91}$ corresponds to the authority of the general custom amended through the ages: 'if all the reason that were dispersed into so many heads were united into one, yet would he not make such a law as the law of England is, because by many successions of ages it hath been fined and refined by so many learned men. ${ }^{92}$

It is by making use of the reason conception that Coke justifies the supremacy of the common law: a perfect expression of reason that commands what must be done and bans the opposite. This highest degree of reasonableness as divine wisdom ${ }^{93}$ may be completed in the human spirit in the form of judicial wisdom. ${ }^{94}$ The common law is the judicial understanding of the divine reasonableness and hence of divine origin: 'without question lex orta est cum mente divina, and this admirable unity and consent in such diversity of things proceeded from God the fountain and founder of all good laws and constitutions. ${ }^{95}$ Thereby common law defends liberty. In the case of the American colonies, the point of rupture was the liberty of no taxation without political, parliamentary representation. This, they argued, was in the spirit of the Magna Carta (1215); this was the occasion by which American theorists differentiated between a fundamental law of nature and ordinary legislation.

\footnotetext{
${ }^{89}$ Coke, Edward (1794), The First Part of the Institutes of the Laws of England, 232b.

${ }^{90}$ Coke, Edward (1794), The First Part of the Institutes of the Laws of England, 232b. Coke's wording mirrors that of Cicero: 'ratio est radius divini luminis.' He continues: 'and by reasoning and debating of grave learned men the darkness of ignorance is expelled, and by the light of legal reason the right is discerned, and thereupon judgement is given according to the law, which is the perfection of reason.'

${ }^{91}$ '[G]ood law, if it be well understood; for non in legendo sed intelligendo leges consistunt.' Coke, Edward (1826), The Reports, Eighth Reports, 167a = 77 ER 726 (The Earl of Cumberland's Case).

${ }^{92}$ Coke, Edward (1794), The First Part of the Institutes of the Laws of England, 97b.

${ }^{93} \mathrm{Cf}$. the differentiating criteria between good and evil which coincides with the divine spirit: orta autem est simul cum mente divina. Cicero (1959), De legibus II, iv, 10, 382.

${ }^{94}[\mathrm{Q}]$ uae cum adolevit atque perfecta est, nominatur rite sapientia. Cicero (1959), De legibus I, viii, 22, 320.

${ }^{95}$ Coke, Edward (1826), The Reports, Third Reports, iv. In the edition in the English Reports, the foreword is not printed.
} 


\subsubsection{Liberty Defending Common Law Versus Discretion Granting Executive from an American Perspective}

In the American colonies the reason-based supremacy of law set itself above all authority, not only above monarchical sovereignty. According to the American body of knowledge on Coke's impact on American liberalism, ${ }^{96}$ the obligation of the prerogative to adhere to an extra-statutory fundamental law (Fundamental Law of Nature and Government ${ }^{97}$; a Law antecedent and paramount to all positive Laws of $m e n^{98}$ ) was adapted to become the binding force of the state goal to protect life, liberty, and possession, after the Declaration of Independence (1776) has replaced the Lockean 'property' 99 with the pursuit of happiness, ${ }^{100}$ though still tracing Locke's idea of property as tied to liberty, consent, and limited government. Opposing Hobbes' fear of submission based on mortal danger, ${ }^{101}$ Locke's idea of self-determination as an a priori ownership in oneself, in one's own manpower and resources, ${ }^{102}$ led to the assumption of freedom and equality as intrinsic rights. ${ }^{103}$ The individual freedom to produce wealth by labour results in the material wealth of human society. ${ }^{104}$ From the restriction of ruling onto the protection of life, liberty, and possession, together with the institutional transferral of rights to the powers of the community, ${ }^{105}$ Locke concludes his conception of ruling and governance as akin to a legal-fiduciary trust, which is held in the interest of the ruled ones. ${ }^{106}$ This amounts to a right of resistance of the people (residual power) in case of misconduct without questioning the institutional persistence of a common supreme power, the legislative power as a whole. ${ }^{107}$

The opposition between common law (which defended liberty) and prerogative (which provided for monarchical discretion) was fundamental to Locke's differentiation between legislative and executive power: 'Where the Legislative and Executive Power are in distinct hands, (as they are in all moderated Monarchies, and well-framed Governments) there the good of the Society requires, that several

\footnotetext{
${ }^{96}$ Cantor (1997); Hostettler (1997); Stoner (1992). Cf. also Müßig (2008a), "Coke, Edward”, column 871-5 for further references.

${ }^{97}$ Locke, John (1963), Second Treatise of Government, chap. XIV, § 159, 392.

${ }^{98}$ Locke, John (1963), Second Treatise of Government, chap. XIV, § 168, 397f.

${ }^{99}$ Locke, John (1963), Second Treatise of Government, chap. IX (Of the Ends of Political Society and Government), § 123ff., 368ff.

${ }^{100}$ Bailyn (1967); Dworetz (1990); Hartz (1955); Schultz (1993); Macpherson (1990).

${ }^{101}$ Bellum omnium contra omnes; homo homini lupus.

${ }^{102}$ Locke, John (1963), Second Treatise of Government, chap. V, § 27, 305-6.

${ }^{103}$ Locke, John (1963), Second Treatise of Government, chap. VII, § 87, 341-2.

${ }^{104}$ Locke, John (1963), Second Treatise of Government, chap. V, § 41, 314-15.

${ }^{105}$ Locke, John (1963), Second Treatise of Government, chap. IX, § 131, 371.

${ }^{106}$ Locke, John (1963), Second Treatise of Government, chap. XIII, § 149, 384-5.

${ }^{107}$ Locke, John (1963), Second Treatise of Government, chap. XIX, § 243, 445-6.
} 
things should be left to the discretion of him, that has the Executive Power., ${ }^{108}$ To the extent that laws passed by the legislative branch did not contain any rule, the power of decision-making was afforded to the monarchical executive that had discretion: 'Many things there are, which the Law can by no means provide for, and those must necessarily be left to the discretion of him, that has the Executive Power in hands, to be ordered by him. ${ }^{109}$ This executive, discretionary decision-making power corresponds to the monarchical prerogative: 'This power to act according to discretion, for the publick good, without the prescription of the Law, and sometimes even against it, is that which is called Prerogative. ${ }^{110}$ The public good was the yardstick for discretionary decisions, '[f]or Prerogative is nothing but the Power of doing publick good without a Rule.'111

Locke, however, was not prepared to leave the decision on the public good to the arbitrary decision of the monarch. While he acknowledged that some decisions were, by necessity, within the purview of the executive discretion 'as the publick good and advantage shall require', he continued: 'nay, 'tis fit that the Laws themselves should in some Cases give way to the Executive Power, or rather to this Fundamental Law of Nature and Government, viz. ${ }^{, 12}$ It was not the will of the ruler, but rather a natural law that existed a priori and was of the highest, extra-statutory nature ('a Law antecedent and paramount to all positive Laws of men') that determined the public good, and it was this natural law to which the discretionary decision of the prerogative had to adhere. As Locke pointed out, ' $[\mathrm{t}] \mathrm{he}$ old Question will be asked in this matter of Prerogative, But who shall be Judge when this Power is made a right use of?' ${ }^{113}$ Locke's answer attributed the 'ultimate determination' of the limits of the prerogative to the 'Law antecedent and paramount to all positive Laws of men'; this was not subject to the final adjudication of any earthly authority. Indeed, if a government were to continuously abuse its exercise of power, the only recourse of the people was to appeal to a morally just 'supreme judge' to vindicate their cause and resistance. Redress could thus be achieved through the acquiescence, alteration, or abolition of the offending government, if the popular appeal was based upon the rectitude of their intentions ('approving consciences'), moral character capable of self-government, and justness of cause: 'yet they have, by a Law antecedent and paramount to all positive Laws of men, reserv'd that ultimate Determination to themselves, which belongs to all Mankind, where there lies no Appeal on Earth, viz. to judges whether they have just Cause to make their Appeal to Heaven. ${ }^{, 14}$

\footnotetext{
${ }^{108}$ Locke, John (1963), Second Treatise of Government, chap. XIV, § 159, 392. Note Locke's formulation of the idea of the 'moderated monarchy.'

${ }^{109}$ Locke, John (1963), Second Treatise of Government, chap. XIV, § 159, 392.

${ }^{110}$ Locke, John (1963), Second Treatise of Government, chap. XIV, §§ 159-60, 393.

${ }^{111}$ Locke, John (1963), Second Treatise of Government, chap. XIV, § 166, 396.

${ }^{112}$ Locke, John (1963), Second Treatise of Government, chap. XIV, § 159, 392.

${ }^{113}$ Locke, John (1963), Second Treatise of Government, chap. XIV, § 168, 397.

${ }^{114}$ Locke, John (1963), Second Treatise of Government, chap. XIV, § 168, 397-8.
} 
What was ground-breaking for the decisive constitutional normativity in the revolutions of the eighteenth century was not the institutional realization of the Treatises' separation of the legislative and executive power as different state functions, but the juridification of the starting point to 'form themselves into a political Society [....and to] become a sovereign State, ${ }^{115}$ which was achieved by building on Locke's notion of the natural right of people. ${ }^{116}$ The reasoning of the Virginian planter and later delegate to the Continental Congress Richard Bland (1710-76) transformed the Lockean state of nature into the settlement 'by Englishmen at their own Expense', after they had decided 'to quit the Society of which they are Members, and to retire to another Country.' 117 Bland's argumentation that 'they recover their natural Freedom and Independence: The Jurisdiction and Sovereignty of the State they have quitted ceases, ${ }^{118}$ was also employed by Benjamin Franklin in his essay 'On the Tenure of the Manor of East Greenwich., 119 This indicates the denial of the Parliament's authority to legislate on colonial internals to be the second legal point of the common law litigation conducted by the Americans.

\subsection{No Westminster Legislation on the Internal Colonial Polities}

The next step in the common law litigation against the Sugar Act of 1764 was the argumentation that the Westminster Parliament should be excluded from all legislation over the domestic affairs of the colonies. ${ }^{120}$ After the differentiation between 'legal' and 'constitutional' and the condemnation of legally-issued statutes infringing upon common law liberties as 'unconstitutional', the American revolutionaries introduced the distinction of the internal colonial polities from the Empire as a whole. Whereas the first are governed by the old liberties and privileges as English subjects (specifically, the right of not being governed by laws made without consent, as indicated in the Magna Carta), the latter falls under the general

\footnotetext{
${ }^{115}$ Bland, Richard (1766), An Inquiry on the rights of the British colonies, cited in Greene (2010), 89.

${ }^{116}$ Locke, John (1963), Second Treatise of Government, chap. XI, § 134, 373-5, and § 136ff., 376ff. Cf. also Dunn (1969), 45-80; Hofmann (2012). Cf. Müßig (2014), "Locke, John”, column 1029-32.

${ }^{117}$ Bland, Richard (1766), An Inquiry on the rights of the British colonies, in Greene (2010), 89.

${ }^{118}$ Bland, Richard (1766), An Inquiry on the rights of the British colonies, in Greene (2010), 88.

${ }^{119}$ Franklin, Benjamin, "On the Tenure of the Manor of East Greenwich" (11 January 1766; sometimes referred to as of 6 January), in Benjamin Franklin's Letters to the Press, ed. Crane (1950), 48.

${ }^{120}$ Greene (2010), 79.
} 
superintending power of the British Parliament. This protest, elaborated by the various provincial assemblies of the thirteen colonies, is remarkable in its references to the legal status quo of the British Empire. So, in 1764, the Connecticut Assembly articulated against the proposed stamp duties that it is a 'fundamental principle of the British Constitution' that 'no law can be made or abrogated without the consent of the people by their representatives. ${ }^{121}$ The wording of the Virginia Assembly's protest referred explicitly to the 'ancient and inestimable Right of being governed by such Laws respecting their internal Polity and Taxation as are derived from their own Consent ${ }^{122}$ - again claimed by the Virginia House of Burgesses and reiterated similarly in public resolutions by the assemblies of Rhode Island, Maryland, and Connecticut in September and October $1765 .^{123}$

Of the nine older North American colonies whose assemblies passed resolutions against the Stamp Act (those of Georgia, North Carolina, Delaware, and New Hampshire did not), four claimed exclusive jurisdiction over both taxation and internal legislation (Virginia, Rhode Island, Maryland, and Connecticut). If one also counts the Massachusetts House's October message to Governor Bernard that the province's authority to make laws for the 'internal government and taxation' had 'been never [...] questioned; but has been constantly recognized by the King and Parliament', ${ }^{124}$ this exclusive jurisdiction applied to a majority of five of the nine colonies. When the American colonies pleaded for 'an exclusive Power of making Laws for their internal Polity and Government,' they made a recourse to 'a perfect internal Liberty, as to the Choice of their own Laws, and in all other Matters that are purely provincial. ${ }^{125}$

\subsubsection{Systematic Distinction of 'Internal' and 'External' Spheres of Colonial Government}

The Virginian Richard Bland was the mastermind for the systematic distinction between "colonies" "internal" and "external" spheres of government." ${ }^{126}$ In The

\footnotetext{
${ }^{121}$ See Footnote 120.

${ }^{122}$ See Footnote 120.

${ }^{123}$ Greene (2010), 79-80, with references (n. 26) to Virginia Petition (18 December 1764), Virginia Resolutions (30 May 1765), Rhode Island Resolves (September 1765), Maryland Resolves (28 September 1765), Connecticut Resolves (25 October 1765), in Edmund (1959), 14, $48,50-1,53,55$. All of the assembly resolutions are conveniently collected in the same volume, at $47-62$.

${ }^{124}$ Massachusetts House to Bernard, 23 October 1765, in The Writings of Samuel Adams, ed. Cushing (1904), vol. I, 17-18.

125 "A Letter to the Gentlemen of the Committee of London Merchants Trading to North America" (London: 1766), 9-10; "Remarks on the Maryland Government," American Magazine 1 (1741), 30, cited according to Greene (2010), 86.

${ }^{126}$ According to Greene's argument in The Constitutional Origins of the American Revolution, 81, and Bailyn's analysis in The Ideological Origins of the American Revolution, 2.13, No. 55.
} 
Colonel Dismounted (1764), he explained that because Virginians were entitled to all of the 'liberties and Privileges of English subjects, they must necessarily have a legal Constitution.' For him the legal English constitution was defined by 'a legislature composed in part of the representatives of the people who may enact laws for the INTERNAL government of the colony and suitable to its various circumstances and occasions.' 127 'Without such a representative,' for Richard Bland 'no law can be made', and therefore he concluded that Westminster Parliament, in which the colonists were not represented, 'had no authority to pass laws for the "INTERNAL government" of the colonies without violating 'the most valuable part' of the colonists' 'Birthright' as Englishmen: the right 'of being governed by laws made with our own consent', as embodied in chapter 12 of the Magna Carta (1215). ${ }^{128}$ Parliament's authority for all aspects of 'EXTERNAL government', however, remained unquestioned. ${ }^{129}$ This argument continued in Bland's second pamphlet, An Inquiry into the Rights of the British Colonies, ${ }^{130}$ which was published early in 1766 after Westminster had passed the Stamp Act against widespread colonial resistance. Bland's associate in the Virginia House of Burgesses, Landon Carter (1710-78), ${ }^{131}$ sang from the same hymn sheet against the Stamp Act and vigorously supported the colonists' claim 'of being solely governed and taxed by Laws made with the Consent of the Majority of their own Representatives, according to an Englishman's inherent Birthright.' 132

The colonists' contention that they were 'the better Englishmen' can also be traced in the note of four members of the Massachusetts Assembly, including Samuel Adams and James Otis, ${ }^{133}$ to a London correspondent in December 1765: 'The general superintending Power of the Parliament over the whole British Empire is clearly admitted here, so far as in our Circumstances is consistent with the

\footnotetext{
${ }^{127}$ Bailyn (1967), 2.13, No. 55. As with those quotes that follow, the emphasis exists in the original.

${ }^{128}$ Willoweit and Seif (=Müßig) (2003), 9. Cf. Bland, Richard (1764), The Colonel Dismounted, in Pamphlets on the American Revolution, ed. Bailyn (1965), 320; cf. also Bailyn (1967), 2.13, No. 55; and Greene (2010), 81.

${ }^{129}$ Bland, Richard (1764), The Colonel Dismounted, in Pamphlets of the American Revolution, ed. Bailyn (1965), 320.

${ }^{130}$ Bland, Richard (1766), An Inquiry on the rights of the British colonies, in Greene (2010), 88.

${ }^{131}$ Carter, Landon (1965), The Diary of Colonel Landon Carter of Sabine Hall, 1752-1778, which provides an account of colonial life immediately prior to the American War of Independence.

${ }^{132}$ Greene (1968).

${ }^{133}$ The catchphrase 'taxation without representation is tyranny' was ascribed to Otis in 1763 , but there is no evidence that he said it. On the other hand, in 1764 Otis wrote, '[That n]o parts of his Majesty's dominions can be taxed without their consent.' Otis, James (1764), Rights of the British Colonies, 65. Cf. also Smith (2011), 174, n. 13; Breen (1998), 378-403; Samuelson (1999), $493-$ 523.
} 
Enjoyment of our essential Rights, as Freemen, and British Subjects. ${ }^{, 134}$ As Adams pointed out, the 'general superintending Power over the whole British Empire' did not cover internal affairs of the colonies. If the colonists were 'indeed [...] British Subjects, (\& they never can brook to be thought anything less) it seems necessary that they should exercise this Power within themselves; for they are not represented in the British Parliam[en]t \& their great Distance renders it impracticable. ${ }^{135}$ Only if each legislature within the Empire had an exclusive legislative authority within its own jurisdiction, according to the Massachusetts Assembly, was it able to ensure 'that equality [of rights and status] which ought ever to subsist among all his Majesty's subjects in his wide extended empire.'136

\subsubsection{Specific Matters of the Colonies' Own Nature Versus General Matters of the Empire}

Stephen Hopkins, Rhode's Island's elected governor, continued on this point still further. 'In an imperial state, which consists of many separate governments each of which hath peculiar Privileges and of which kind it is evident that the empire of Great Britain is,' he argued, 'no single part, though greater than another part, is by that superiority entitled to make laws for or to tax such lesser part.' This was the reason, Hopkins believed, why each of the colonies had to have 'a legislature within itself to take care of its interests and provide for its peace and internal government. ${ }^{137}$ Again, as with Richard Bland and the Massachusetts representatives, Westminster's authority for matters of a general nature within the British Empire remained unquestioned. The New York pamphleteer William Hicks similarly stands in this line: To govern the colonies 'according to the principles of the national constitution,' he pointed out, required the colonies to be 'vested with authority of legislation' over all provincial matters 'and have right to be represented in their Assemblies, in whom [alone] that authority [was] lodged.' ${ }^{138}$ A colonists' supporter in London describes the autonomy of the internal government as the same for the English people and the American people: 'Our Constitution is so tender of the

\footnotetext{
${ }^{134}$ Greene (2010), 82.

${ }^{135}$ Samuel Adams to Reverend G[eorge] W[hitfield], 11 November 1765, in Greene (2010), $82 \mathrm{f}$.

${ }^{136}$ Otis, James et al. to Dennys De Berdt, 20 December 1765, in The Writings of Samuel Adams, ed. Cushing (1904), vol. I, 20, 28-9, 67. See also Greene (2010), 83.

${ }^{137}$ Hopkins, Stephen (1765), The Rights of the Colonies Examined, in Pamphlets of the American Revolution, ed. Bailyn (1965), vol. I, 512, 519. See also Greene (2010), 83.

${ }^{138}$ [Hicks, William] (1765), Considerations upon the Rights of the Colonies to the Privileges of British Subjects, 11; [Fitch, Thomas et al.] (1764), Reasons Why the British Colonies, in America, Should Not Be Charged with Internal Taxes, in Pamphlets of the American Revolution, ed. Bailyn (1965), vol. I, 395, 406. Cf. the argumentation in Greene (2010), 84.
} 
Rights and Liberties of the Subject,' wrote the anonymous author of A Vindication of the Rights of the Americans in 1765, 'that the People of England have their Representatives, the Scotch theirs, the Welsh theirs, the Irish theirs, [and] the Americans theirs, for they have Assemblies and Parliaments, each of which represent the Bulk of the People, of that Generality, or Division, for which such Assembly or Parliament is appointed to be held.' ${ }^{3} 9$ 'In extensive Territories not confined to one Island, or one Continent, but dispersed through a great Part of the Globe,' this British voice for the Rights of the American people carries on, 'the Laws cannot be put into execution, nor the Rights of the People preserved, without their being arranged into several Classes' of coordinate legislatures, because each, presumably, has its own exclusive jurisdiction over the internal affairs of its territory. ${ }^{140}$

All these American statements of the second half of the seventeenth century, from Richard Bland to William Hicks, circumscribe the exemption of the imperial constitution from the English constitution of parliamentary supremacy. The customary coinage of the colonial status was furthermore elaborated in the third legal argument developed by the American in their own case.

\subsection{Self-reliance of the British Imperial 'Constitution'}

The third legal point was the self-reliance of the imperial constitution with its principled customary limitation, to be differentiated from the British constitution of parliamentary supremacy that had emerged by the $1760 \mathrm{~s}$. In the line of arguments, which held Great Britain and the British Empire to be distinct political entities, the focus lies on history, when different groups of colonists each set forth to establish a new settlement in North America in different places, at different times, for different reasons. Some were commercial ventures, others havens of religious liberty for those who founded them, and at least Georgia began as a penal colony. How could the British Empire be administered and coordinated in the colonies, then, when the colonies were at least two months away by ship? One way would have been to forge a workable intercolonial union that could coordinate the individual colonial governments for shared goals without repeated recourse concerning individual policy decisions to the mother country. The failure of this goal narrowed the British options down to long-distance governance: holding the American colonies together for purposes of defense and foreign policy and dealing with them directly to regulate trade and raise revenue. Thus, by 1763, at the conclusion of the Seven Years' War, the only certainty about constitutional arrangements with the colonies was uncertainty. Blackstone's Commentaries only provided his analysis of the

\footnotetext{
${ }^{139} \mathrm{~A}$ Vindication of the Rights of the Americans, $10-11$, cited according to N.N. (1765b), Greene (2010), 84-5.

${ }^{140}$ See Footnote 139 .
} 
state-organisational status of the 'American plantations' as 'distinct dominions.' He analysed them as 'subject [...] to the control of the parliament; though (like Ireland, Man and the rest) not bound by any acts of parliament, unless particularly named. ${ }^{141} \mathrm{He}$ stressed the self-reliance of the colonial justice: 'they have courts of justice of their own,' with a line of appeal 'to the king in council here in England. ${ }^{142} \mathrm{He}$ acknowledged their own legislation: 'Their general assemblies which are their house of commons, together with their council of state being their upper house, with the concurrence of the king or his representative the governor, make law suited to their own emergencies.' ${ }^{143}$

The nature of Parliament's relation to the colonies, however, had not been defined in the Commentaries. This was the gap for the legal argument of exempting the imperial constitution out of the sovereignty of Parliament. The reasoning was as follows: After the Glorious Revolution and the usage of the Bill of Rights during succeeding decades, Britain had obviously consented to the doctrine of parliamentary supremacy in the domestic sphere. In the colonies, though, neither the people at large through custom nor their representatives in the several colonial legislatures had given such consent. There was no point in extending the British constitution to the Empire conglomerate, as Richard Bland has put it, because it was 'in vain to search into the civil Constitution of England for Directions in fixing the proper Connexion between the Colonies and the Mother Kingdom. ${ }^{144}$ Whereas the British constitution was based around the sovereignty of Parliament, the imperial constitution through which their colonies were connected to Great Britain remained based on the old common law liberties, usages, and customs, according to the American view.

It was the 'loose texture' of Britain's 'extended and diversified' empire- to borrow from the wording of Colonel Isaac Barré's speech in the House of Commons during the Stamp Act crisis ${ }^{145}$ - that allowed for its deviating interpretations, either in an unitarian way (from the perspective of London), or in a federal way (from the perspective of the colonies). ${ }^{146}$ The metropolitan discourse thought the British Empire to be an unitarian state centred around the sovereign Parliament

\footnotetext{
${ }^{141}$ Blackstone, William (1979), Commentaries on the Laws of England, vol. I, Introduction, sec. IV, 105.

${ }^{142}$ Blackstone, William (1979), Commentaries on the Laws of England, vol. I, Introduction, sec. IV, 105.

${ }^{143}$ See Footnote 142.

${ }^{144}$ Bland, Richard (1766), An Inquiry on the rights of the British colonies, in Revolutionary Virginia, ed. Van Schreeven and Scribner (1973), vol. I, 34.

${ }^{145}$ Barré, Isaac, Speech to the House of Commons, 24 February 1766, in Proceedings and Debates of the British Parliaments respecting North America, ed. Simmons and Thomas (1983), vol. II, 296. Cited according to Greene (2010), 102 (n. 74).

${ }^{146}$ Mauduit, Jasper (1766), Legislative Authority of the British Parliament, 11. Cf. Greene (2010), 102 (n. 74).
} 
and 'organized on the principle of devolution. ${ }^{, 147}$ From the colonial point of view, there was no concentration of authority within the Empire as being 'predominantly federal in practice, ${ }^{, 148}$ with London's authority limited by the delegated colonial authorities. These constitutional positions on both sides of the Atlantic were irreconcilable.

For the colonies the British move towards extending Westminster as an intercolonial Parliament with full authority in taxation and all other colonial concerns caused fear of 'a dangerous federal union.' ${ }^{149}$ In the metropolitan power centre only singular voices in the Commons and the Lords conceded that there were and have to be limits upon Parliament's colonial authority. Charles Pratt, one of the architects of the Pratt-Yorke opinion of $1757,{ }^{150}$ had by now been elevated to the title of Lord Camden; he favoured 'the sovereign authority, the omnipotence of the legislature,' but clearly pointed out that there were 'some things it [Parliament] cannot do. ${ }^{151}$ In his view the sovereignty did not empower Parliament to act 'contrary to the fundamental laws of nature, contrary to the fundamental laws of this Constitution. ${ }^{152}$ His speeches of 2 February and 7 March 1766 were pervaded by implicit distinctions between ordinary law and fundamental law, either borrowing 'from the Law of Reason and of Nature' or 'from [the] Custom and Usage [of] our own Constitution. ${ }^{153}$ Lord Camden and the likeminded William Pitt the Elder $^{154}$ in the

\footnotetext{
${ }^{147}$ N.N. (1765a), The Political Balance, 45. Cf. Greene (2010), 102 (n. 74).

${ }^{148}$ Tucker and Hendrickson (1982), 175, 179. Cf. Greene (2010), 102 (n. 74).

${ }^{149}$ Charles Yorke, speech of 15 February 1765, in Proceedings and Debates of the British Parliaments respecting North America, ed. Simmons and Thomas (1983), vol. II, 26. Cited according to Greene (2010), 103.

${ }^{150}$ Charles Pratt (1714-94), afterwards Lord Camden: A former attorney general and then chief justice of common pleas, Pratt was one of the authors of the Pratt-Yorke opinion of 1757 (also known as the Camden-Yorke opinion) on the question of the right to own and govern new colonies. The opinion was issued in response to a petition from the British East India Company, over their land disputes either bought or conquerred. According to the official legal Pratt-Yorke opinion, the British East India Company held property in India according to treaty, but these lands would be considered under the sovereignty of Great Britain in the same way that territories acquired by conquest were. This opinion came to apply elsewhere of the developing British Empire.

${ }^{151}$ Camden speeches, 2 February and 7 March 1766, in Proceedings and Debates of the British Parliaments respecting North America, ed. Simmons and Thomas (1983), vol. II, 125ff., 321ff.

${ }^{152}$ See Footnote 151.

${ }^{153}$ See Footnote 151.

${ }^{154}$ William Pitt, 1st Earl of Chatham (1708-78): William Pitt (often referred to as Pitt the Elder, to distinguish from his son of the same name), was an important English politician of the eighteenth century, and counterpart of Robert Walpole. An orator of some repute, he was a member of the Parliament since 1735, from 1766 and 1768 he served as prime minister (beforehand between 1757 and 1761 under Newcastle he had a leading role). In spite of his attempts, both military and political, he was unable to halt the American independence movement, and he died in 1778. His son, William Pitt the Younger (1759-1806), was similarly a highly influential politician and, twice, prime minister. "Pitt, William", in Die Brockhaus Enzyklopädie Online, https://brockhaus.de/sites/default/files/pdfpermlink/pitt-william73e49415.pdf (6 May 2014) accessed 14 March 2017.
} 
Commons were convinced that fundamental laws and old common law liberties restricted and bound also the legislative body itself and could not be abrogated by any parliamentary sovereignty. For them the ancient British principle of no taxation without representation (chapt. 12 Magna Carta 1215) ranked among these fundamental laws. ${ }^{155}$ Due to the authoritative myth of the Magna Carta and this guarantee, which has already been into the articles of the Barons, ${ }^{156}$ Parliament had 'never levied Internal Taxes on any subject without their own consent. ${ }^{157}$ Before the differentiation between Parliament's authority to tax and its authority to legislate for the colonies emerged in the colonial discourse, Pitt held it explicitly 'essentially necessary to liberty. ${ }^{, 158}$ For the 1st Earl of Chatham and contrary to Robert Walpole, 'this kingdom, as the supreme governing and legislative power, has always bound the colonies by her laws, by her regulations, and restrictions in trade, in navigation, in manufactures - in every thing, except that of taking their money out of their pockets without their consent. ${ }^{159}$

Most of the London establishment, though, regarded the power to tax as 'a necessary part of every Supreme Legislative Authority' and believed 'if they have not that Power over America, they have none, \& then America is at once a Kingdom of itself', ${ }^{160}$ as the Connecticut agent Jared Ingersoll reported to his constituents in February 1765. From the London perspective, the logic of the parliamentary supremacy left no space for customary restraints upon the authority of Parliament. Parliament was 'the only natural, constitutional Seat of complete Jurisdiction in the Kingdom' and that jurisdiction necessarily extended not just throughout the home islands but 'over the property and person of every inhabitant of a British colony' as well. ${ }^{161}$ In his reply to Camden, William Murray, Lord Mansfield (1705-93) ${ }^{162}$ stressed that Parliament represented 'the whole British empire' and had 'authority to

\footnotetext{
${ }^{155}$ Willoweit and Seif (=Müßig) (2003), 9.

${ }^{156}$ Stubbs (ed.) (1905), 289ff.

${ }^{157}$ Camden's speech, 7 March 1766; Pitt's Speech, 14 January 1766, in Proceedings and Debates of the British Parliaments respecting North America, ed. Simmons and Thomas (1983), vol. II, 81-92, 320-2. Cited according to Greene (2010), 95 (n. 59).

${ }^{158}$ Pitt's speech, 14 January 1766, in Proceedings and Debates of the British Parliaments respecting North America, ed. Simmons and Thomas (1983), vol. II, 81-92, 320-2. Cited according to Greene (2010), 95 (n. 59).

${ }^{159}$ See Footnote 158.

${ }^{160}$ Jared Ingersoll to Thomas Fitch, February 1765, in Prologue to Revolution, ed. Morgan (1959), 30. Cited according to Greene (2010), 100 (n. 71).

${ }^{161}$ N.N. (1766), The General Opposition of the Colonies to the Payment of the Stamp Duty, 25-6; [William Knox] (1765a), A Letter to a Member of Parliament, 21; [William Knox] (1765), The claim of the colonies to an exemption from internal taxes imposed by authority of Parliament, 2. Cited according to Greene (2010), 97 (n. 62).

${ }^{162}$ Lord Mansfield was the judge in in the Somerset's Case. Here it was held that slavery itself could not exist in England, because it contradicted the grant object of English law: Liberty. It was therefore not compatible with the natural laws of the mankind. Shaw (1926), 6; Nadelhaft (1966), 196.
} 
bind every part and every subject without the least distinction' in matters of taxation as well as legislation. ${ }^{163}$ This position in the debate over the repeal of the Stamp Act is consistent with his reasoning in the famous Somerset case, ${ }^{164}$ in which an American resident was barred from exercising his rights over his slave in England as against the natural laws of mankind and the common law liberty, 'if not [allowed] by positive law.' 165 Though celebrated for his enlightened advocacy for freedom, Mansfield implicitly held that a statute could feasibly allow slavery, though the institution of slavery was contrary to fundamental laws.

Pitt and Camden were lone voices crying in the wilderness, whereas for most contemporaries unlimited sovereignty lay in the king-in-Parliament. The overwhelming majority position in the Stamp Act discourse held that customary restrictions upon Westminster's authority were synonymous with infringements against the sovereignty of the British crown over the colonies. Representing the metropolitan opinion, Lord Egmont argued that Parliament, by virtue of its 'supreme, absolute and unlimited' power, could levy taxes 'upon the People not by right of their having representatives but [by virtue of their] being subjects to the Government.' 166

Regardless these arguments, the strength of colonial resistance against the Stamp Act forced Westminster to retract it. However, the repeal was accompanied by the Declaratory Act, which explicitly asserted that Westminster 'had hath, and of right ought to have, full power and authority to make laws and statutes of sufficient force and validity to bind the colonies and people of America [...] in all cases whatsoever.' ${ }^{167}$ This consolidation of the unlimited and inimitable sovereignty of Parliament effectively meant, for the colonists, the fading of 'the essence of all their British ancestors had fought for, took the very savour out of that fine Anglo-Saxon liberty for which the sages and patriots of England had died. ${ }^{168}$ Having slammed the door, London had thus set the last scene for the American case conducted like a common law litigation. The legal question of the binding authority of usage and custom for the colonial constitutions was still very much open to debate, and it was

\footnotetext{
${ }^{163}$ Mansfield's speeches, 3 February 1766, in Proceedings and Debates of the British Parliaments respecting North America, ed. Simmons and Thomas (1983), vol. II, 128-130. Cited according to Greene (2010), 99.

${ }^{164}$ Somerset v. Stewart (1772) 20 St Tr 1 per Lord Mansfield, who held that English law did not permit a United States resident to exercise his rights over his slave, declaring slavery to be 'so odious that nothing can be suffered to support it but positive law.' As Mansfield pointed out, no such law existed.

${ }^{165}$ Somerset v. Stewart (1772) $20 \mathrm{St}$ Tr 1.

${ }^{166}$ Egmont's speech, 6 March 1766, in Proceedings and Debates of the British Parliaments respecting North America, ed. Simmons and Thomas (1983), vol. II, 126-7, 320-321. Cited according to Greene (2010), 101 (n. 72), as of 7 March 1766.

${ }^{167}$ American Colonies Act (1766), 6 Geo 3 c 12.

${ }^{168}$ Mims (1941), 71.
} 
exactly this assessment which was needed for justification of the 'rioting crowds' in the upheavals against Stamp Act. ${ }^{169}$

\subsection{Legal Force of Custom in the Unsettled Connexion of the Colonies to Britain}

In their protest against both interference in local affairs by Westminster through legislation and direct parliamentary taxation throughout the Stamp Act crisis, the American colonists put enormous stress on the traditional foundation of their rights in the old common law liberties. In making their arguments for exemption from Westminster legislation and taxation, the colonies' spokesmen relied on the assumption that the colonial constitutions 'had been established by long custom and' that custom 'was currently sanctioned by accepted usage., ${ }^{170}$ This redress to custom does not appear to be mere rhetoric. Of course, their argumentation would not have been so convincing if it had not exactly matched the supremacy of law concept established by Sir Edward Coke on the understanding of common law as immortal custom. 'Times immemorial' was and remains a commonly-employed phrase by English lawyers. Thus, the customary basis of colonial constitutions might have been felt by the colonists to be a legal argument in itself, one that could not be surmounted by common lawyers. The latter could not help but accept whatever had been done in a community in the very earliest times to be legal, and whatever had been abstained from to be illegal. When the colonists denounced London's violation of their 'old rights' through the alteration of their 'customary constitution[s]', ${ }^{171}$ they were in line with 'a common law way of thinking about politics [...] viewing each controversy as a matter, not for free invention or for fresh deduction from first principles, but for judicious choice, with attention to precedent always in order but authoritative solution always elusive. ${ }^{, 12}$ In the tradition of the seventeenth-century reasoning the colonists emphasised continuity rather than novelty and established 'some reason greater than custom alone, for by common law, unreasonable customs have no legal force. ${ }^{173}$ At the heart of this reason-based customary longing for rights as Englishmen was the Sullivan Draft ${ }^{174}$ of the Declaration and Resolves on Colonial rights of the First Continental Congress of 14 October $1774^{175}$ which reads as an American adoption of the English Bill of Rights

\footnotetext{
${ }^{169}$ Reid (1974), 1067.

${ }^{170}$ Reid (1976), 341; Reid (1995); Grey (1978), 863.

${ }^{171}$ Grey (1978), 853-4.

${ }^{172}$ Stoner (1992), 177.

${ }^{173}$ See Footnote 172.

${ }^{174}$ The Sullivan Draft was named for Major General John Sullivan (1740-95), the delegate from New Hampshire (and, later, governor) who first presented the resolutions.

${ }^{175}$ Journals of the Continental Congress, 1774-1789, ed. Ford (1904), vol. I, 63-73.
} 
of $1689 .{ }^{176}$ Indeed, as late as the nineteenth century, the attachment to the common law traditions was vivid, as could be heard in Edmund Burke's Speech on Conciliation with America: the colonists were "not only devoted to liberty, but to liberty according to English ideas, and on English principles. Abstract liberty, like other abstractions, is not to be found [...] Their love of liberty, as with you, [is] fixed and attached on this specific point of taxation. ${ }^{177}$

Following the Boston Tea Party and the adoption of the Intolerable Acts, delegates gathered on 5 September 1774, at Philadelphia, in what was to become the First Continental Congress. Every colony but Georgia was represented. They voted on the next day to appoint a committee 'to state the rights of the Colonies in general, the several instances in which these rights are violated or infringed, and the means most proper to be pursued for obtaining a restoration of them. ${ }^{178}$ This led to the proposal of Joseph Galloway, a prominent young Pennsylvanian lawyer. ${ }^{179}$ Galloway's Plan of Union was a conservative attempt to unite the colonies within the Empire. In addition, it advocated the creation of an American colonial parliament to act in coordination with Westminster. ${ }^{180}$ Though it achieved a not inconsiderable degree of support in the First Continental Congress, Galloway's Plan of Union was opposed by the more radical delegates in the Congress. Consequently, it was introduced to the Congress on 28 September 1774, with the latter formally declining to adopt the plan, six votes to five, on 22 or (sometimes reported) 27 October. With Galloway's proposal rejected, the delegates instead adopted the Declaration of Colonial Rights, ${ }^{181}$ based on Sullivan's draft. This draft, formulated

\footnotetext{
${ }^{176}$ Historical Notes of the American Colonies and Revolution, ed. Griffith (1843), 114.

${ }^{177}$ Burke's speech, in The works of the right honourable Edmund Burke, ed. Rivington and Rivington (1826), 49.

${ }^{178}$ Journals of the Continental Congress, 1774-1789, ed. Ford (1904), vol. I, 26.

${ }^{179}$ Joseph Galloway (1731-1803): A lawyer by training, Galloway had already made a name for himself in Pennsylvania at a young age. He became a member of the Assembly of Pennsylvania in 1756, and ten years later became the speaker of the Assembly. He took a critical stance with regards to the Stamp Act, but he was a Loyalist who opposed independence. His Plan of Union, which offered a compromise while remaining under the British umbrella, was rejected by the Continental Congress. As a result of Galloway's support for Britain, after 1778 he migrated to Britain. See, for reference, the three-part biography published by Baldwin (1902a, b, c), 161-91 (no. 2), 289-321 (no. 3), and 417-42 (no. 4).

${ }^{180}$ Galloway's Plan of Union mooted an American Parliament to act in conjunction with Westminster, with Westminster maintaining a right of veto. The king would elect a president-general to act as the enactor of the laws. Baldwin (1902c), 417ff. Baldwin suggests that the Plan of Union was popular, but its failure was the result of Galloway's opposition to the Revolutionary Suffolk Resolves. This would indicate that the Continental Congress was largely staffed by moderates, with the Resolves being a singular sticking point. On the other hand, Kelly and Harbison argue that the discussion surrounding the Resolves demonstrates that extremists were gaining the upper hand. Baldwin (1902b), 317; Kelly and Harbison (1970), 83.

${ }^{181}$ Curiously, the Plan of Union does not appear in the minutes of the Congress. Some historians have suggested that it was deliberately expunged; others, taking into account Charles Thomson's reputation for honesty, assume that this was a genuine oversight on his part - a curious notion, given the importance of the Plan. Baldwin (1902b), 317 (n. 3). Cf. also Wood (2015).
} 
in the manner of common law, ${ }^{182}$ began by listing Westminster's unconstitutional acts; the three statutes of $1774^{183}$ were denounced as 'impolitic, unjust, and cruel, as well as unconstitutional, and most dangerous and destructive of American rights.' ${ }^{184}$ Against 'these arbitrary proceedings of Parliament and administration', as the Sullivan Draft put it:

[t]he good people of the several colonies [...] justly alarmed at these arbitrary proceedings of Parliament and administration, have severally elected, constituted, and appointed deputies to meet and sit in General Congress, in the city of Philadelphia, in order to obtain such establishment, as that their religion, laws, and liberties may not be subverted. ${ }^{185}$

The Sullivan Draft continued with the justification of the colonists' rights as the customary rights of Englishmen. As with those of Englishmen still on the Home Islands, these rights emanated from the 'very earliest times' of their ancestors:

Whereupon the deputies so appointed being now assembled, in a full and free representation of these colonies, taking into their most serious consideration, the best means of attaining the ends aforesaid, do, in the first place, as Englishmen, their ancestors in like cases have usually done, for asserting and vindicating their rights and liberties, declare, That the inhabitants of the English Colonies in North America, by the immutable laws of nature, the principles of the English constitution, and the several charters or compacts, have the following rights. ${ }^{186}$

What followed was the explicit enumeration of these rights; these were related to 'the rights, liberties, and immunities of free and natural-born subjects, within the realm of England.' ${ }^{187}$ Finally, the draft concluded with reference to the

\footnotetext{
${ }^{182}$ Journals of the Continental Congress, 1774-1789, ed. Ford (1904), vol. I, 63-73.

${ }^{183}$ These three acts were, respectively, "An act to discontinue, in such manner and for such time as are therein mentioned, the landing and discharging, lading, or shipping of goods, wares and merchandise, at the town, and within the harbor of Boston, in the province of Massachusetts Bay, in North America" (Boston Port Act), "An act for the better regulating the government of the province of the Massachusetts Bay in New England" (Massachusetts Government Act), and "An act for the impartial administration of justice, in the cases of persons questioned for any act done by them in the execution of the law, or for the suppression of riots and tumults, in the province of the Massachusetts Bay, in New England." (Administration of Justice Act). Afterwards, another statute- "for making more effectual provision for the government of the province of Quebec, etc." (Quebec Act) - also became contentious. Historical Notes of the American Colonies and Revolution, ed. Griffith (1843), 114.

${ }^{184}$ Historical Notes of the American Colonies and Revolution, ed. Griffith (1843), 114.

${ }^{185}$ Historical Notes of the American Colonies and Revolution, ed. Griffith (1843), 114-15. At this stage, the 'several colonies' to which Sullivan referred were New Hampshire, Massachusetts Bay, Rhode Island and Providence Plantations, Connecticut, New York, New Jersey, Pennsylvania, Newcastle, Kent and Sussex on Delaware, Maryland, Virginia, North Carolina, and South Carolina.

${ }^{186}$ Historical Notes of the American Colonies and Revolution, ed. Griffith, (1843), 115.

${ }^{187}$ These rights are explicitly defined in Historical Notes of the American Colonies and Revolution, ed. Griffith (1843), 115-16.
} 
immutability and irreversibility of the rights and liberties, 'which cannot be legally taken from them, altered or abridged by any power whatever, without their own consent, by their representatives in their several provincial legislatures. ${ }^{, 188}$ The ending also reinforced the 'Americans as fellow-subjects in Great Britain', and framed the preceding text not as a revolutionary document, but rather a vehicle 'to restore harmony between Great Britain and the American colonies. ${ }^{189}$

As long as the American colonists deemed themselves common subjects of the same king, and argued on the customary level of their old rights as Englishmen, there could not be the idea of the precedence of a written constitutional text. All questions of precedence were mere questions of the applicability of ordinary law. In the case of collision of colonial 'laws, by-laws, usages and customs' with English law, Blackstone held them to be 'utterly void and of no effect." ${ }^{190}$ Only in 1776 did the Americans 'substitute' their old rights as Englishmen with 'natural freedoms.' Taking the plunge and reorienting the American conception of the law according to natural law reasoning instead of the immortal customs of common law appeared to be constitutional 'pragmatism. ${ }^{, 191}$ In doing so, they declared independence and were no longer common subjects of the same king. Therefore, any invocation of their customary rights as Englishmen had been voided.

\section{Establishing Constitution as Law}

\subsection{Emergence of the Constituent American People}

\subsubsection{Natural Law 'Basis and Foundation of Government'}

It was the Virginia Bill of Rights ${ }^{192}$ that constituted the decisive move away from the colonists' justifications on the grounds of traditional common law liberties. In this document, no reference at all was made to the customary rights and liberties of the colonists as Englishmen. The legitimising authority was not 'custom' but

\footnotetext{
${ }^{188}$ Historical Notes of the American Colonies and Revolution, ed. Griffith (1843), 116.

${ }^{189}$ Historical Notes of the American Colonies and Revolution, ed. Griffith (1843), 116-17.

${ }^{190}$ Blackstone, William (1979), Commentaries on the Laws of England, vol. I, 105.

${ }^{191}$ Cf. Bernstein, "The Current Global Resurgence of Pragmatism", lecture at the Katholische Akademie in Bayern, Munich, 21 March 2017.

${ }^{192}$ The Virginia Declaration of Rights had a tremendous influence on the development of the American constitutional process. It proclaimed the natural equity of man, individual rights, and that the right to govern derived its legitimacy from the people. This was demonstrated by its wording, in which its origins were stated to be in the 'representatives of the good people of Virginia, assembled in full and free convention; which rights do pertain to them, and their posterity, as the basis and foundation of government.' It was modelled on the English Bill of Rights. Hunt (1917), 276, “In Convention—June 12, 1776", Postscript, no. 72 (14 June 1776), 1. Virginia Bill of Rights in: McClain (1913), 382.
} 
'nature', the blueprint being the law of nature according to Locke, and the concept '[t]hat all men are by nature equally free and independent and have certain inherent rights, of which, when they enter into a state of society, they cannot, by any compact, deprive or divest their posterity; namely, the enjoyment of life and liberty, with the means of acquiring and possessing property, and pursuing and obtaining happiness and safety.' Written by George Mason, and adopted by the Fifth Virginia Convention on 12 June 1776, the claimed generality as 'the basis and foundation of government' marked the Virginia Bill of Rights as a revolutionary caesura. ${ }^{193}$ The first formulation of popular sovereignty can be found in Section 2: 'That all power is vested in, and consequently derived from, the people; that magistrates are their trustees and servants and at all times amenable to them.' The later constitutional framework of the United States Constitution (1787) is already evident here in the provision on the government ${ }^{194}$ and the separation between the legislature and the executive. ${ }^{195}$ Section 7 recalls the supremacy of legislation: 'That all power of suspending laws, or the execution of laws, by any authority, without consent of the representatives of the people, is injurious to their rights and ought not to be exercised. ${ }^{196}$ Section 15 makes references to fundamental principles of higher-ranking authority, but does not yet recognise the precedence of the written constitution: 'That no free government, or the blessings of liberty, can be preserved to any people but by a firm adherence to justice, moderation, temperance, frugality, and

\footnotetext{
${ }^{193} \mathrm{Cf}$. le but de toute institution politique in the diction of the preamble of the Declaration of the Rights of Man and Citizen (1789), in Willoweit and Seif (=Müßig) (2003), 250.

${ }^{194}$ Virginia Bill of Rights in: McClain (1913), 383. 'Section 3. That government is, or ought to be, instituted for the common benefit, protection, and security, of the people, nation, or community; of all the various modes and forms of government, that is best, which is capable of producing the greatest degree of happiness and safety, and is most effectually secured against the danger of mal-administration; and that, when any government shall be found inadequate or contrary to these purposes, a majority of the community hath an indubitable, unalienable, and indefeasible right to reform, alter, or abolish it, in such manner as shall be judged most conducive to the public weal. Section 4. That no man, or set of men, are entitled to exclusive or separate emoluments or privileges from the community, but in consideration of public services; which, not being descendible, neither ought the offices of magistrate, legislator, or judge to be hereditary.' Cf. "In Convention-June 12, 1776", Postscript, no. 72 (14 June 1776), 1.

${ }^{195}$ Virginia Bill of Rights in: McClain (1913), 383. 'Section 5. That the legislative and executive powers of the state should be separate and distinct from the judiciary; and that the members of the two first may be restrained from oppression, by feeling and participating the burthens of the people, they should, at fixed periods, be reduced to a private station, return into that body from which they were originally taken, and the vacancies be supplied by frequent, certain, and regular elections, in which all, or any part, of the former members, to be again eligible, or ineligible, as the laws shall direct. Section 6 . That elections of members to serve as representatives of the people, in assembly, ought to be free; and that all men, having sufficient evidence of permanent common interest with, and attachment to, the community, have the right of suffrage, and cannot be taxed or deprived of their property for public uses without their own consent or that of their representatives so elected, nor bound by any law to which they have not, in like manner, assented, for the public good.' Cf. 'In Convention-June 12, 1776”, Postscript, no. 72 (14 June 1776), 1.

${ }^{196}$ Stimson (2004), 79.
} 
virtue and by frequent recurrence to fundamental principles. ${ }^{197}$ Nevertheless, the Virginia Bill of Rights was regarded at the level of ordinary legislation, not vested with any superior rank, and still analogous to common law. Later declarations of rights after the break with England included a series of rights in accordance with natural law preambles. These rights had previously been enjoyed by the Americans as rights of Englishman and codified law which has already existed; now, however, they had been elevated to the new level of superior constitutions. ${ }^{198}$

\subsubsection{Independence from Being Subjects of the 'Same' King}

In his essay entitled 'The Irrelevance of the Declaration,' the New York historian John Phillip Reid argued that the important part of the Declaration was not its preamble, but rather the charges it levelled against George III. ${ }^{199}$ He was right to do so. In summer 1775, John Dickinson's Olive Branch Petition addressed a catalogue of colonists' complaints to Westminster; its failure to elicit positive action encouraged the Americans to seriously consider the role of the king as a nonpartisan patriot monarch of his whole people. This, naturally, must have included the Americans themselves, as George III's common, English subjects. Yet, as it became increasingly obvious in 1775-6 that the king was not willing to intervene in favour of the colonists against Westminster's self-understanding as a superior legislative power, the colonists resorted to formulating a new course of political action that included both independence from Britain and the creation of 'an AMERICAN COMMONWEALTH.' On their way to declaring themselves independent the American colonists made it clear that they were about to terminate the submission under British statehood as 'common subjects of the same King., 200

From the point of view of the Americans, Parliament had no say in the relations between Britain and the colonies; according to the Chief Justice of the Rhode Island Supreme Court, Stephen Hopkins, it was 'absurd to suppose that the common people of Great Britain have a sovereign and absolute authority over their fellow subjects in America, or [indeed] any sort of power whatsoever over them. ${ }^{201}$ When George III refused his arbitration role requested by the colonies, he assumed in their view full responsibility for the injustices suffered by the colonies. This responsibility was subsequently established in the initial wording of the Declaration of Independence of 4 July 1776:

\footnotetext{
${ }^{197}$ Vetterli and Bryner (1987), 76.

${ }^{198}$ Stourzh (2015), 58.

${ }^{199}$ Reid (1981), 46-89.

200“'Letter from a Plain Yeoman", Providence Gazette, 11 May 1765, cited in Prologue to Revolution, ed. Morgan (1959), 73.

${ }^{201}$ Philalethes, New York Gazette Post Boy, 8 May 1766, cited in Greene (2010), 88 (n. 41).
} 
Such has been the patient sufferance of these Colonies; and such is now the necessity which constrains them to alter their former Systems of Government. The history of the present King of Great Britain is a history of repeated injuries and usurpations, all having in direct object the establishment of an absolute Tyranny over these States. To prove this, let Facts be submitted to a candid world. ${ }^{202}$

A close reading of the Declaration immediately reminds the reader of the structure of the English Bill of Rights of 1689. This began with an enumeration of all the infringements of James II against the 'lawes and liberties of this Kingdome. ${ }^{203}$

After the list of all these justifications for the revolution the Declaration states:

Nor have We been wanting in attentions to our British brethren. We have warned them from time to time of attempts by their legislature to extend an unwarrantable jurisdiction over us. We have reminded them of the circumstances of our emigration and settlement here. We have appealed to their native justice and magnanimity, and we have conjured them by the ties of our common kindred [sic!] to disavow these usurpations, which, would inevitably interrupt our connections and correspondence.

Even at this seemingly terminal point in Anglo-American relations, the Declaration of Independence still highlighted their discursive commonalities. Nonetheless, the 'British brethren' left their common, transatlantic kin no other choice, but to declare themselves independent, as ' $[\mathrm{t}]$ hey [...] have been deaf to the voice of justice and of consanguinity.' By addressing 'necessity' the American colonies claimed their right of resistance as a measure of self-defence, just as Parliament itself has done standing against the Stuart king, Charles I, when it issued the Militia Ordinance of $1642 .^{204}$ The Declaration concluded its justifications by stating that ' $[\mathrm{w}] \mathrm{e}$ must, therefore, acquiesce in the necessity, which denounces our Separation, and hold them, as we hold the rest of mankind, Enemies in War, in Peace Friends. ${ }^{205}$ The connection with the decision for war and peace in the ending wording makes the range of this recourse to 'necessity' obvious. The central issue was the question of sovereignty: who had the final say when it really mattered. ${ }^{206}$

\subsubsection{Constitutional American People of the United Colonies (1776-8)}

The Declaration of Independence invoked a united American people, one singular constitutional population, distinct from the British colonial power: 'When [...] it becomes necessary for one people to dissolve the political bands which have

\footnotetext{
${ }^{202}$ Fröschl (2014); Wills (1978), passim; Armitage (2002), 39-45.

${ }^{203}$ Willoweit and Seif (=Müßig) (2003), 236-7.

${ }^{204}$ The Constitutional Documents of the Puritan Revolution 1625-1660, ed. Gardiner (1906), No. 54, 254-5, 257.

${ }^{205}$ Fröschl (2014); Wills (1978), passim; Armitage (2002), 39-45.

${ }^{206}$ For further argumentation cf. Müßig (2008b).
} 
connected them with another.' 207 The redress of the initial wording to 'the separate and equal station to which the Laws of Nature and of Nature's God entitle them,' thereby alluding to the old phrase from Bracton ('under God and the law') increases the appearance of unity. In spite of this, the American people did not enter the stage of history homogenously, in the form of a unitarian state, but rather as a federal union of thirteen individual states. Moreover, though the unanimity of the Declaration suggested unity, the Declaration itself included the seemingly irreconcilable concept that 'these United Colonies [...] ought to be Free and Independent States [...] And that as Free and Independent states, they have full power to levy War, conclude Peace, contract Alliances, establish Commerce, and do all other Acts and Things which Independent States may of right do. 208

This fundamental contradiction of 1776, in which (supposedly) one people was divided amongst and represented by thirteen autonomous states, was determinative for the history of the United States, as almost all discussions on the rights of the individual states vis-à-vis the central government-for instance, the various States' Rights debates, the Jacksonian Nullification Crisis of 1832-7, and the secession of the Confederate states in 1860-1 ${ }^{209}$ — may be traced back to it. Indeed, common political discourse customarily referred to the United States in the plural ('the United States are'), with the modern singular usage ('the United States is') only entering general usage after the end of the Civil War in $1865 .^{210}$ Furthermore, South Carolina's Declaration of Secession (24 December 1860), which was one of the direct casus belli of the Civil War, explicitly justified the separation from the Union by invoking the Declaration of Independence and the Articles of Confederation:

In pursuance of this Declaration of Independence [1776], each of the thirteen States proceeded to exercise its separate sovereignty; adopted for itself a Constitution, and appointed officers for the administration of government in all its departments - Legislative, Executive and Judicial. For purposes of defense, they united their arms and their counsels; and, in 1777, they entered into a League known as the Articles of Confederation, whereby they agreed to entrust the administration of their external relations to a common agent, known as the Congress of the United States, expressly declaring in the first article, that each State retains its sovereignty, freedom and independence, and every power, jurisdiction and right which is not, by this Confederation, expressly delegated to the United States in Congress assembled. $^{211}$

South Carolina's justification for secession was that it had never surrendered the sovereignty it had won as an independent state in 1776, neither to the Continental Congress under the Articles, nor to the Union under the 1787 Constitution. With the explicit reference to the Treaty of Paris of September 1783, which brought the War

\footnotetext{
${ }^{207}$ Text of the Declaration in Thomas Jefferson, Writings, ed. Peterson (1984), 13-14. For the assessment as one constitutional people cf. Mansfield (1989), 290.

${ }^{208}$ Thomas Jefferson, Writings, ed. Peterson (1984), 24.

${ }^{209}$ Ellis (1987), passim.

${ }^{210} \mathrm{Cf}$. Fröschl (2015), 40 .

${ }^{211}$ Bruun and Crosby eds. (1999), 340-2.
} 
of Independence to a close, and the acknowledgement of the individually-named 'United States' by the 'Britannic Majesty', this single-state legal focus position was even more underlined and emphasised. In the line of the South Carolinian arguments for the separation from the United States lay also the recourse to the "two great principles asserted by the Colonies, namely: the right of a State to govern itself; and the right of a people to abolish a Government when it becomes destructive of the ends for which it was instituted. ${ }^{, 212}$ Undisputable was the final conclusion of the secessionist state, 'that each Colony became and was recognized by the mother Country as a free, sovereign and independent State. ${ }^{213}$

This nineteenth-century reasoning reflects the debates at the end of the Stamp Act crisis, revolving around the legitimacy and desirability of a federal union or an incorporating union. For a Barbadian pamphleteer, 'Our Governments [...] are founded on similar Principles', ${ }^{214}$ and in March 1766 an anonymous writer in the Pennsylvania Journal proposed 'a confederacy of states, independent of each other, yet united under one head', concluding that 'all the powers of legislation may subsist full and complete in each part, and their respective legislatures be absolutely independent of each other. ${ }^{, 215}$ The struggle of the 'Colonies [to be] coordinate members with each other and with Great Britain, of an empire united by a common executive sovereign, but not united by any common legislative sovereign' was the driving force behind the American Revolution, more so than any other claim or grievance, as James Madison later observed. ${ }^{216}$ The necessity of a federative union was highlighted by the Declaration of Independence, since only a united action in the war against Great Britain seemed likely to bring success to the colonies. But separation from Britain by no means resolved this ancient question. To the contrary, it made it even more challenging by complementing it with the equally vexing problem of how to forge a viable political and constitutional union out of thirteen distinct polities that had previously been tied together only by their common relationship to the British Empire through the emerging imperial constitution. ${ }^{217}$ Therefore the Articles of Confederation and perpetual Union between the States of New Hampshire, Massachusetts Bay, Rhode Island and Providence Plantations, Connecticut, New York, New Jersey, Pennsylvania, Delaware, Maryland, Virginia, North Carolina, South Carolina and Georgia were only adopted on 15 November 1777 after long discussions, ${ }^{218}$ though any incorporating union (such as the example of England and Scotland since 1707) was out of question. The first two articles stipulated that ' $[\mathrm{t}] \mathrm{he}$ style of this confederacy shall be "The United States of

\footnotetext{
${ }^{212}$ Bruun and Crosby (eds.) (1999), 340-2.

${ }^{213}$ See Footnote 212.

${ }^{214}$ Cited in Prologue to Revolution, ed. Morgan (1959), 20.

${ }^{215}$ F. L., Pennsylvania Journal, 13 March 1766, in Prologue to Revolution, ed. Morgan (1959), 91.

${ }^{216}$ James Madison, "Notes on the Resolutions, 1799-1800", in The Writings of James Madison, ed. Hunt (1906), vol. VI, 373.

${ }^{217}$ Greene (2010), 188.

${ }^{218}$ The ratification process was finished with the adoption of Maryland on 1 March 1781.
} 
America.", and "[e]ach state retains its sovereignty, freedom and independence [...] which is not expressly delegated to the United States in Congress assembled.' ${ }^{219}$ The longest of all the provisions, Article IX, amounted to half of the text of the Articles of Confederation. It regulated that 'the united states in congress assembled, shall have the sole and exclusive right and power of determining on peace and war [...] of sending and receiving ambassadors - entering into treaties and alliances [...] The united states in congress assembled shall never engage in a war $[\ldots]$ nor enter into any treaties or alliances [...] unless nine states assent to the same.'

All decisions of importance and relevance had to be made by nine out of thirteen states, which amounted to a necessary majority of seventy percent of the individual states represented in Congress. Ten years later, the majority in the debates of the federative United States Constitution of 30 July till 1 August 1787, borrowing from the historical examples of the Netherlands, the Swiss Confederation, and the Holy Roman Empire, pointed out that not individuals but individual states were represented in Congress, ${ }^{220}$ which was to be done equally and with the need of unanimity for general and fundamental matters. ${ }^{221}$ This proves that winning independence in 1783, though effectively securing the original goal of the revolutionaries to gain local control over local affairs, left the question of how to bring the individual states into an 'effective union.' The state organisational issue to distribute authority between the centre and the peripheries was the primary concern of the American constitutional discourse during the 1780s and particularly during the national debate over the establishment of a new federal union 1787-8. Indeed, it might have been the driving force behind the recovering of the constitution as one legal written document at the core of a polity, defining its government's powers and responsibilities and the limits on those powers and specifying the rights of the people. In examining the United States Constitution of 1787, its focus on sovereignty issues between the Union and single states and its understanding as supreme legal codex for the existence of the union (and therefore nation) becomes readily apparent.

\footnotetext{
${ }^{219}$ Reproduced in The Debate on the Constitution: Federalist and Antifederalist Speeches, Articles and Letters during the Struggle over Ratification, ed. Bailyn (1993), vol. I, 954-64, and vol. II, 926-36.

${ }^{220}$ Thomas Jefferson, Writings, ed. Peterson (1984), 28-31.

${ }^{221}$ The opposition (most prominently, Benjamin Franklin) argued that population figures or economic power should be represented proportionately, rather than equally.
} 


\subsection{Constitution as Supreme Legal Codex for Central State Issues}

\subsubsection{Focus on the Division of Sovereignty Between Union and Single States}

The United States Constitution was meant to be a ground-breaking document. Given this, its preamble, beginning with the phraseology '[w]e the people of America do hereby declare', seems uncharacteristically cautious. There is no other explicit reference to the sovereignty question within the preamble. This is perhaps because of the perceived experimental character of the Constitution itself, and its aim to establish an expansive federal republic by majority decision. The architects of the Constitution were well aware of this character. In his Federalist Paper No. 85, Alexander Hamilton invoked the words the Scottish Enlightenment philosopher David Hume, in order to point out that ' $[\mathrm{t}] \mathrm{o}$ balance a large state or society [...] on general laws, is a work of so great difficulty [that] time must bring it to perfection, and the feeling of inconveniences must correct the mistakes which they INEVITABLY fall into in their first trials and experiments. ${ }^{222}$

The delineation of competencies between the Union and the States (Art. 1, sec. $8,9,10$ ) is, along with the separation of powers (Art. I, sec. 1 and Art. 2, sec. 1$)^{223}$ the leading constitutional theme in the organisation of the United States. The address to an internal and external defensive sovereignty ${ }^{224}$ is not necessary. The Constitution articulated the rights of the Congress in legislation (Art. I, sec. 8) - the classical rights of sovereignty - and reduced correspondingly the rights of the union states, thus demonstrating the focus on the division of sovereignty between union and union states. It designed a federal state with a strong centralised power. With the American founding fathers having Blackstone's Commentaries as a

\footnotetext{
${ }^{222}$ The Federalist Papers, published originally as a series of eighty-five essays in two New York newspapers between 1787 and 1788, were originally intended to help sway New York public opinion towards acceptance of the draft produced at the Constitutional Convention. Collected and published together in 1788, they have since become the acknowledged, authentic commentary on the interpretation of the United States Constitution, and are consulted by the Supreme Court. Though the essays were written under a collective nom-de-plume ('Publius'), there were three authors: Alexander Hamilton (1755/1757-1804), who wrote the majority; James Madison (17511836), the 'father of the Constitution'; and John Jay (1745-1829), who focused mostly on foreign affairs and whose contributions were limited to five essays due to illness. Alexander Hamilton, Federalist No. 85, in Hamilton, Madison, and Jay (1961), The Federalist Papers, 526-7. Cf. David Hume, "Of the Rise and Progress of the Arts and Sciences", in Hume (1788), Essays and Treatises, vol. I, 112.

${ }^{223}$ The Federalist's individual analysis of the three powers (Legislature: No. 55-66; Executive: No. 67-77; Judicial: No. 78-83) puts forward the idea of a mixed constitution, in which, borrowing from Montesquieu's phrasing, every power is accorded a virtue according to its function: the legislative, prudence, because of the plurality in advising; the executive, energy, because of its concentration of power in one person. Cf. Müßig (2013a), paper 5, 15 (n. 129).

${ }^{224} \mathrm{Cf}$. Müßig (2016), 35-6, 50-1, 74-5.
} 
model, the image of the President as surrogate monarch was already on the table, and elucidated in Art. 2, sec. 1's provision that 'the executive power shall be vested in a President. ${ }^{225}$ Legislation (Art. I sec. 1, 8) and budgetary sovereignty (Art. I, sec. 7) were subject to the two chambers of Congress: the House of Representatives, being the elected representatives of the people (Art. I, sec. 2), and the Senate, being the representatives of the individual states (Art. I, sec. 3). The bicameral system was created to enable compromises between the interests of the big states and the small ones. In the House of Representatives, every state was to have representatives according to its size (Art. I, sec. 2); in the Senate, according to the principle of equality of the states, every state was to have two senators (Art. I, sec. 3).

\subsubsection{The Constitution as Guarantee for the Existence of the Union}

According to the Federalists, such as Hamilton, Madison, and John Jay, the supremacy of the constitution was self-evident, because it was the benchmark for the action of all political powers. In the constitution, not only a political order that is able to protect freedom and property is manifested, but it is also the only system that can guarantee the existence of the nation. According to Federalist Paper No. 84, written by Hamilton (writing under the pseudonym 'Publius', meaning 'of the people'), '[t]he great bulk of the citizens of America are with reason convinced, that Union is the basis of their political happiness. ${ }^{226}$ This conviction arose because this 'great bulk of the citizens' was represented by 'a national government' (No. 85). ${ }^{227}$ As for his rhetorical question 'whether [...] the proposed Constitution has not been satisfactorily vindicated from the aspersions thrown upon it; and whether it has not been shown to be worthy of the public approbation, and necessary to the public safety and prosperity', Hamilton explained that a decision upon the constitution was a decision upon the "very existence of the nation." 228 His

\footnotetext{
${ }^{225}$ The president is directly elected by the people, by way of electors. Despite accountability to Congress (Art. 2 Section 3 United States Constitution), the president does not depend on the Congress. The president in turn cannot dissolve Congress. The president's staff consists of his personal advisers and is not accountable to Congress. The president's important role in the legislative process, despite having no formal right of legislative initiative, emerges from the right to 'recommend to their consideration such measures as he shall judge necessary and expedient' (Art. 2 Section 3). Further, the president has a suspensive veto (Art. 1 Section 7). Cf. Muß (2013), passim; Beke-Martos (2012), 155-174.

${ }^{226}$ Hamilton, Alexander, Federalist No. 84, in Hamilton, Madison, and Jay (1961), The Federalist Papers.

227،A NATION, without a NATIONAL GOVERNMENT, is, in my view, an awful spectacle'. Hamilton, Alexander, Federalist No. 84, in Hamilton, Madison, and Jay (1961), The Federalist Papers, 527.

${ }^{228}$ 'No partial motive, no particular interest, no pride of opinion, no temporary passion or prejudice, will justify to himself, to his country, or to his posterity, an improper election of the part he is to act. Let him beware of an obstinate adherence to party; let him reflect that the object upon which he is to decide is not a particular interest of the community, but the very existence of the nation;
} 
explanations that the consent to the constitution should be governed by '[n]o partial motive, no particular interest, no pride of opinion, no temporary passion or prejudice, ${ }^{229}$ with the decisive aspect being 'not a particular interest of the community, but the very existence of the nation', marks the superiority of the general will approving the constitution over the consensus to a statute.

The opposition to the federal Constitution, which in 1787 fostered the development of hierarchical laws, has been extensively investigated by Gerald Stourzh, who likened it to the political thought of the nineteenth-century Austrian theorist Adolf J. Merkl. ${ }^{230}$ As an example of this, Stourzh referred to the correspondence of an anonymous anti-Federalist farmer. In his sixth letter, the farmer (assumed to be the New Yorker Melancton Smith) wrote:

Of rights, some are natural and unalienable, of which even the people cannot deprive individuals: Some are constitutional or fundamental; these cannot be altered or abolished by the ordinary laws; but the people, by express acts, may alter or abolish them. These, such as the trial by jury, the benefits of the writ of habeas corpus, \&c., individuals claim under the solemn compacts of the people, as constitutions, or at least under laws so strengthened by long usage as not to be repealable by the ordinary legislature - and some are common or mere legal rights, that is, such as individuals claim under laws which the ordinary legislature may alter or abolish at pleasure. ${ }^{231}$

From this anti-Federalist opposition against the precedence of constitution over the ordinary laws (both of the union and of the federated states), it becomes clear that the development of the supremacy of constitution in the American constitutional discourse also comprised the political issue of the state-organisational relationship between union and single federated states; its preeminence was fostered by the equivalence of the existence of the Union and the coming-into-existence of the Constitution.

\subsubsection{Constitutional Silence on Precedence}

The supremacy of the Constitution as proclaimed in Art. VI clause 2 of the 1787 text was left without statement how to implement the precedence at either federal or

and let him remember that a majority of America has already given its sanction to the plan which he is to approve or reject.' Hamilton, Alexander, Federalist No. 84, in Hamilton, Madison, and Jay (1961), The Federalist Papers, 523.

${ }^{229}$ Hamilton, Alexander, Federalist No. 84, in Hamilton, Madison, and Jay (1961), The Federalist Papers, 523.

${ }^{230}$ For more on Hans Kelsen and Adolf J. Merkl, please refer to the contribution by Thomas Olechowski; for a condense overview of Stourzh' long-standing research on constitutional precedence please refer to his essay, both in this volume.

${ }^{231}$ Letters from the Federal Farmer, letter 6, in Storing (ed.) (1981), 261. Only recently has Smith been assumed to be the author; Smith was a prominent critic and opponent of the United States Constitution. See also Stourzh (1999), 123, republished in Stourzh (2007), 321. It is through these works by Stourzh that Smith's letter, its meaning, and its importance has been brought to my attention. 
single state level. ${ }^{232}$ This seems to owe to the discussion leading from the $1760 \mathrm{~s}$, which saw judicial review as a contradiction of popular sovereignty; according to the introductory preamble, it was this popular sovereignty that legitimated constitutional legislation. ${ }^{233}$ This reluctance to affirm constitutional supremacy should also be understood by reference to the common law context of the American discourse. In the leading Bonham's Case ${ }^{234}$ known also in the colonies, Coke formulated the precedence of common law even over the laws of Parliament. ${ }^{235}$ The willingness of the colonies to adhere to this reasoning was only bolstered during their struggles against Westminster legislation.

The counter-position of the sovereignty of Parliament ${ }^{236}$ was about to cause much unease in the colonies. Contrary to Coke, Blackstone's Commentaries stipulated that, '[w]here the common law and a statute differ, the common law gives place to the statute. ${ }^{237}$ This established the precedence of the legislative over the judicial. But even before Blackstone's definition of parliamentary sovereignty was able to gain a foothold in the colonies, the American discourse had already adopted the position that there must be limitations to Westminster's jurisdiction.

With this we return to the justification of the American Revolution as an act of resistance against the unconstitutional action of the English Parliament. It is true that the elected colonial representative bodies did not expressly confess to the invalidity of unpopular parliamentary laws in the protest against the motherland, ${ }^{238}$ but popular sovereignty took parliamentary sovereignty off the table. The idea of popular sovereignty was formulated by the Committee of Correspondence of the

\footnotetext{
${ }^{232}$ Since the Supreme Court's decision in Marbury v. Madison (5 U.S. (1. Cranch) 137) in 1803, the competence to decide the constitutionality of laws passed by Congress is recognised.

${ }^{233}$ 'We the people of the United States do ordain and establish this constitution for the United States of America.' Cited by Willoweit and Seif (=Müßig) (2003), 255.

234، And it appears in our books that in many cases the common laws will control acts of parliament and sometimes adjudge them to be utterly void: for when an act of parliament is against common right or reason, or repugnant or impossible to be performed, the common law will control it and adjudge such act to be void.' 8 Co.Rep. 107a = 77 ER 638; Plucknett (1926/27), 34.

${ }^{235} \mathrm{Coke}$, however, did not decide on the issue of sovereignty, leaving it open to interpretation. See also Mosse (1950), 160-1.

${ }^{236}$ Concerning Parliament's claim of sovereignty as the highest common law court in the English constitutional struggles of the seventeenth century, see Müßig (2006a), 48ff.

${ }^{237}$ Blackstone, William, Commentaries on the Laws of England, Introduction, section III, 89. See also Jezierski (1971), 95-106.

${ }^{238}$ House of Burgesses of Virginia 1764: 'And if it were proper for the Parliament to impose Taxes on the Colonies at all, which the Remonstrants take Leave to think would be inconsistent with the fundamental Principles of the Constitution, the Exercise of that Power at this Time would be ruinous to Virginia.' Cited in Prologue to Revolution, ed. Morgan (1959), 17; Resolution of Maryland 1765: 'Unconstitutional and a Direct Violation of the Rights of the Freemen of this Province' (Prologue to Revolution, 53); Resolution of Massachusetts 1765: 'That all Acts made, by any Power whatever, other than the General Assembly of the Province, imposing Taxes on the Inhabitants are Infringements of our inherent and unalienable Rights, as Men and British Subjects: and render void the most valuable Declarations of our Charter' (Prologue to Revolution, 57).
} 
city of Boston for the first time in 1772, which quickly spread to the other colonies. ${ }^{239}$ With the Virginia Bill of Rights of 1776, the dam broke. ${ }^{240}$

Nonetheless, the 1787 Constitution remained cautious in its implementation of popular sovereignty, in contrast to the celebratory rhetoric of its preamble. Regardless the importance of the Virginia Bill of Rights eleven years earlier, by 1787 conservative reservations against the people as the sovereign power were still insurmountable. In the Philadelphia Constitutional Convention, the conviction that unlimited popular sovereignty could actually endanger the Constitution still prevailed. $^{241}$ The exclusion of direct popular involvement in the constitutional amendment process, and the introduction of the bicameral system went in the same direction. $^{242}$ Art. V of the 1787 Constitution clearly demonstrates the distrust of direct popular involvement in this amendment process:

The Congress, whenever two thirds of both Houses shall deem it necessary, shall propose Amendments to this Constitution, or, on the Application of the Legislatures of two thirds of the several States, shall call a Convention for proposing Amendments, which, in either Case, shall be valid to all Intents and Purposes, as Part of this Constitution, when ratified by the Legislatures of three fourths of the several States, or by Conventions in three fourths thereof, as the one or the other Mode of Ratification may be proposed by the Congress; Provided that no Amendment which may be made prior to the Year One thousand eight hundred and eight shall in any Manner affect the first and fourth Clauses in the Ninth Section of the first Article; and that no State, without its Consent, shall be deprived of its equal Suffrage in the Senate. ${ }^{243}$

Furthermore, the 1787 text contained no declaration of human rights. It was only in 1791 that the Bill of Rights became part of the Constitution due to conditions set

\footnotetext{
239،All men have a Right to remain in a State of Nature as long as they please: And in case of intolerable Oppression, Civil or Religious, to leave the Society they belong to, and enter into another.-When Men enter into Society, it is by voluntary consent; and they have a right to demand and insist upon the performance of such conditions, and previous limitations as form an equitable original compact.-Every natural Right not expressly given up or form the nature of a Social Compact necessarily ceded remains.-All positive and civil laws, should conform as far as possible, to the Law of natural reason and equity.' The Writings of Samuel Adams, ed. Cushing (1904), vol. II, 351-2. Concerning the revolutionary theoretical significance of the idea of popular sovereignty in the American Revolution see among many Engel (1961), 211; Arendt (1963), 152; Wood (1969), 353-354; Adams (1973), 138-40.

${ }^{240}$ 'That all power is vested in, and consequently derived from, the people; that magistrates are their trustees and servants, and at all times amenable to them [...] that government is, or ought to be, instituted for the common benefit [...]; and that, when any government shall be found inadequate or contrary to these purposes, a majority of the community hath an indubitable, inalienable, and indefeasible right to reform, alter, or abolish it, in such manner as shall be judged most conducive to the public weal.' Swindler (ed.) (1979), 49. See also Stourzh (1976), 397ff.

${ }^{241}$ At the meeting of 21 July 1787, for example, James Madison referred to unlimited popular sovereignty as 'the real source of danger to the American Constitutions.' Cited in The Records of the Federal Convention of 1787, ed. Farrand (1911), vol. III, 74.

${ }^{242}$ Constitutional amendments require a two-thirds majority in both houses of Congress and must also be ratified by three-quarters of the States by legislatures or constitutional conventions (Art. V). ${ }^{243}$ Willoweit and Seif (=Müßig) (2003), 275-6.
} 
out during the debates of ratification in the individual states (Amendments). They lay down a catalogue of individual rights, including those of freedom of religion, speech, and assembly, as well as the inviolability of the person and property. In America - the New World - class differentiations were a memory of the old continent. For that reason, the idea of equality was not as much emphasised as in the French Declaration of the Rights of Man and Citizen, while the American guarantees of freedom of assembly and the right of petition (Article 1 of the Amendments) have no equivalent in the French Declaration. At this point the beginning of a tradition becomes noticeable, through which the United States fostered a unique self-characterisation that differentiated it from its European forebears. This continued after independence and was strongly emphasised in the First Amendment of the United States Constitution 15 December 1791: The federal legislature was prohibited from passing resolutions concerning the creation of a state religion or the prohibition of the free practice of religion. This prohibition for the federal legislature also includes the restriction of the freedom of speech and press, as well as the freedom of assembly and the right to petition. ${ }^{244}$

Constitutional jurisdiction, which was crucial for the precedence of constitution, was not included into the 1787 text, as there was no majority in the Convention for so strong a constitutional jurisdiction. ${ }^{245}$ Nevertheless, the need for an authoritative final judge in disputes between the centre and the periphery - disputes that had been unsolvable in the years between 1765 and 1776-contributed to the American development of a judicial review and to the revision of Locke's concept of there being no competent earthly judge between the legislature and the population.

\subsection{Farewell to the Lockean 'Inter legislatorem et populum nullus in terris est judex'}

According to his letter about tolerance ('Epistola de tolerantia', 1689), for John Locke there was no judge on earth between the legislation and the people. This role could only be occupied by God, and it was God who personified the figure of judgemental resistance against executive or legislative excess. ${ }^{246}$ With the

\footnotetext{
${ }^{244}$ The First Amendment was adopted on 15 December 1791. Here it was established that 'Congress shall make no law respecting an establishment of religion, or prohibiting the free exercise thereof; or abridging the freedom of speech, or of the press; or the right of the people peaceably to assemble, and to petition the Government for a redress of grievances.' It is part of the Bill of Rights, which was enacted by popular pressure in order to explicitly establish the guarantees of individual rights in the face of governmental interference. Nowak and Rotunda (ed.) (1991), 937.

${ }^{245}$ For details, see Dippel (1987), 150.

${ }^{246}$ Locke (1989), A Letter Concerning Toleration, 86. In 1689, Locke answered the question: Quis erit inter eos judex? - who shall be the judge between them? - with: solus deus (God alone). My argumentation here follows Stourzh (2015), 113-14.
} 
separation of legislation and constitution, or the distinction between superior constitutional law and ordinary statutory law, the Americans entertained the possibility of having a secular judge between the legislation and the people. This would take the form of judges who were authorised to measure the statutory law against the 'higher' will of the American people, as embodied by the constitution. The higher legitimation by the constituent general will was explained by Hamilton in his Federalist Paper No. 85.

This process indeed commenced during the 1780s in some of the federal states of America, especially in the state of North Carolina. By the competence for ordinary jurisdiction to measure the statutory law against the 'higher' will of the people, in other words the constitution, the feudal right of resistance, as it is assumed by Locke-where God as judge means resistance-was replaced by the (constitutional) courts. ${ }^{247}$ The federal jurisdiction adopted this opinion; as a result, it was applied to the famous legal case of Marbury v. Madison (1803), which is considered to be the foundation of the 'judicial review' - the prerogative of the judges to examine constitutionality or unconstitutionality. Marbury v. Madison held praeter legem that '[i]t is emphatically the duty of the Judicial Department to say what the law is. Those who apply the rule to particular cases must, of necessity, expound and interpret the rule', and that the Constitution was the superior measurement for ordinary statutes ('If two laws conflict with each other, the Court must decide on the operation of each. If courts are to regard the Constitution, and the Constitution is superior to any ordinary act of the legislature, the Constitution, and not such ordinary act, must govern the case to which they both apply'). However, it is crucial to analyse the context of this decision. That context is provided by Hamilton's plea for the introduction of a judicial review, made fifteen years earlier.

The interpretative authority of jurisdiction and the fundamental character of the Constitution were the starting points for the argumentation set forth in The Federalist No. 78. According to Hamilton:

The interpretation of the laws is the proper and peculiar province of the courts. A constitution is, in fact, and must be regarded by the judges, as a fundamental law. It therefore belongs to them to ascertain its meaning, as well as the meaning of any particular act proceeding from the legislative body. If there should happen to be an irreconcilable variance between the two, that which has the superior obligation and validity ought, of course, to be preferred; or, in other words, the Constitution ought to be preferred to the statute, the intention of the people to the intention of their agents. ${ }^{248}$

James R. Stoner argues ${ }^{249}$ that Hamilton's plea for the judicial review relied on common law reasoning, irrespective the latter's super-elevation of Parliament's wisdom (also: ultimum sapientiae) ${ }^{250}$ not to enact any statute 'against the truth' due

\footnotetext{
${ }^{247}$ Stourzh (1989), 73.

${ }^{248}$ Hamilton, Alexander, Federalist No. 78, in Hamilton, Madison, and Jay (1961), The Federalist Papers, 467.

${ }^{249}$ Stoner (1992), 207-9 (n. 41).

${ }^{250}$ Coke, Edward (1797), The Institutes of the Law of England, Second to Fourth Parts, Part IV, 3.
} 
to the knowledge of the represented subjects of the whole realm. ${ }^{251}$ Hamilton overcame this well-known line of precedence against judicial review, also attached to Bonham's case, ${ }^{252}$ by asserting that a written constitution is a law and therefore examining the violation of constitution by statute is to be held analogous to the clash of two statutes. If two statutes on the level of the same legislative authority were incompatible, it is 'the nature and reason of thing' ${ }^{253}$ that decides for the preference of the more recent. A minore ad maius the analogy leads to preference for a constitutional provision over a conflicting statute, as 'the nature and reason of thing' says so a fortiori, if the legal provisions of a superior authority were at risk of being infringed. Hamilton's statement of the different legal quality of a constitution relied on his assessment of the uniqueness of the constituent power, which he expressed in The Federalist No. 83, ${ }^{254}$ and his tolerance towards implicit, unwritten powers, as argued in The Federalist No. 33. ${ }^{255}$ Irrespective of the lack of express constitutional competences to enforce the goals and limits of a written constitution, such a judicial power of 'mitigating the severity and confining the operation of [unjust and partial] laws, ${ }^{, 256}$ was inferred from the Constitution. ${ }^{257}$ Anti-Federalist critics, writing under the pseudonym 'Brutus', condemned the idea of judicial review, on the grounds of unelected judges having the competence to review and nullify acts of elected legislative representatives. ${ }^{258}$ In response, ${ }^{259}$ Hamilton

\footnotetext{
${ }^{251}$ Coke, Edward (1826), The Reports, Eleventh Reports, 14a = 77 ER 1163 (Priddle and Napper's Case). Whereas Thomas Smith (De Republica Anglorum) and William Lambarde (Eirenarcha) emphasise consensus of the represented subjects to the parliamentary statute, Coke stresses the knowledge of the represented subjects on the parliamentary statute: 'the law intends that every person hath knowledge thereof, for the parliament represents the body of the whole realm.' Coke, Edward (1797), The Institutes of the Law of England, Second to Fourth Parts, Part IV, 26. The knowledge of the represented subjects on the parliamentary statute is not an original thought, new is only the reduction of the representation away from the consensus and only to the aspect of knowledge. Cf. Crompton, Richard (1637), L'authoritie et jurisdiction, fol. $16^{\mathrm{r}}$.

${ }^{252}$ Coke's argumentation in Priddle and Napper's Case starts: 'And as it is said in Powden...' which refers to 8 Co.Rep. 107a = 77 ER 638 (Dr Bonham's Case).

${ }^{253}$ Hamilton, Alexander, Federalist No. 78, in Hamilton, Madison, and Jay (1961), The Federalist Papers, 468.

${ }^{254}$ Hamilton, Alexander, Federalist No. 83, in Hamilton, Madison, and Jay (1961), The Federalist Papers, 497.

${ }^{255}$ Hamilton, Alexander, Federalist No. 33, in Hamilton, Madison, and Jay (1961), The Federalist Papers, 205.

${ }^{256}$ Hamilton, Alexander, Federalist No. 78, in Hamilton, Madison, and Jay (1961), The Federalist Papers, 470.

${ }^{257}$ See Footnote 255.

${ }^{258}$ 'Brutus', Essay XI, in Storing ed. (1981), vol. II, 418, 420.

${ }^{259}$ 'Brutus', Essay XI, in Storing ed. (1981), vol. II, 358-452. Stoner refers to the complete text of Brutus's letter. Stoner considers Hamilton's opening comments in Federalist No. 81 on the power of constructing laws according to their spirit to be a direct response to Brutus' Essay XI. Stoner (1992), 208 (n. 45). See also Diamond (1976), 249-81.
} 
argued that 'in voiding unconstitutional acts the courts serve as the people's champion. ${ }^{260}$

This defence of judicial review in No. 78 can only be understood in the common law context of artificial reason, which was established as the seventeenth-century basis for supremacy of law under the auspices of the oft-quoted Sir Edward Coke. The conception of 'artificial reason', elucidated in the seventeenth-century precedent Prohibitions des Roy, ${ }^{261}$ was established as being superior to the 'natural reason' of the monarch; this was transformed in the Federalists' discourse into the 'solemn and authoritative' reason of a constituent assembly fully aware of the 'Decisive Constitutional Normativity' and its necessity to prevail over the 'momentary inclination' of the people represented by legislature. ${ }^{262}$ To continue this argument, it is the spirit (or, rather, reason) of the common law that no particular legislative act nor any specific legal ruling has the final word on what is just, ${ }^{263}$ but only the 'collective mind of the profession' which adopted the mantle of authority customarily represented by popular consent. ${ }^{264}$

It was in this manner that seventeenth-century common law was the bulwark against Stuart absolutism; ${ }^{265}$ artificial reason replaced general custom, more as an interpretative authority ${ }^{266}$ rather than as legislative consensus. ${ }^{267}$ With this as the common law basis of Hamilton's argumentation, it is not difficult to follow Publius (Hamilton) in assessing the judges as 'the bulwarks of a limited Constitution'268 and 'faithful guardians of the Constitution, ${ }^{269}$ the people as its 'natural

\footnotetext{
${ }^{260}$ Stoner (1992), 209.

${ }^{261}$ Prohibitions del Roy $(1607=$ Mich. 5 Jacobi 1) 12 Co.Rep. $64=77$ ER 1342-1343 per Edward Coke, C.J.

${ }^{262}$ Hamilton, Alexander, Federalist No. 78, in Hamilton, Madison, and Jay (1961), The Federalist Papers, 469-70.

${ }^{263}$ According to Stoner, ' $[\mathrm{t}$ ]he most vivid illustration of this way of thinking I know is the criticism of the Supreme Court Decision in Dred Scott by the great common lawyer, Abraham Lincoln.' Stoner (1992), 264 (n. 55). See also Johannsen (ed.) (1965), passim.

${ }^{264}$ Finch, Henry (1759), A Description of the Common Laws of England, 52-3. Cf. also Dodderidge, John (1631), The English Lawyer, 103; Prest (1977), 326-7; Doe (1990), 26; Ives (1983), 161

${ }^{265}$ Gray (1980), 25-6; Gray (1992), 85-121; Lewis (1968), 330-1.

${ }^{266}$ The authority of the general custom for the common law, however, is not negated. Cf. explicitly Coke, Edward (1826), The Reports, Ninth Reports, 75b = 77 ER 843 (Combes's Case).

${ }^{267}$ Coke, Edward (1826), The Reports, Second Reports, 81a = 76 ER 597 (Lord Cromwel's Case); Coke, Edward (1826), The Reports, Sixth Reports 5b = 77 ER 261 (Sir John Molyn's Case).

${ }^{268}$ Hamilton, Alexander, Federalist No. 78, in Hamilton, Madison, and Jay (1961), The Federalist Papers, 469.

${ }^{269}$ Hamilton, Alexander, Federalist No. 78, in Hamilton, Madison, and Jay (1961), The Federalist Papers, 470.
} 
Guardians, ${ }^{270}$ and 'the general spirit of the people and of the government' ${ }^{271}$ as 'the only solid basis of all our rights.',272

\section{Summary of Sections 3 and 4}

For all that the American Revolution and the subsequent United States Constitution were, indeed, revolutionary, this does not mean that either was unprecedented or unheralded. On the contrary: at every step in the struggle, first with Britain and then amongst themselves, the minds fashioning the American future continually referred back to the concepts of law and legitimacy. Unsurprisingly, these concepts had their origins in the Old World of Europe, as befitting a new society consecrated upon the foundations of the old. The push for independence was not solely a military endeavour but also a legal one, as the leading figures of the Revolution referred to the guiding lights of English common law-William Blackstone and Edward Coke -in order to demonstrate that it was, in fact, England that had forsaken English law, by denying loyal English subjects (as the American colonists, until the very end, argued themselves to be) their rights as Englishmen. This included the right of representation (which could not conceivably be achieved through the institution of the Westminster Parliament) and the right not to be taxed without this aforementioned representation. In part, this explains the ultimate appeal of rebellion: to the Americans, it was not they who were breaking the law by revolting against Britain, but in fact the British who were acting illegally by denying fundamental rights under common law. To the Americans, they were the 'better Englishmen' than the English.

Having established this legitimacy of revolution, the Americans were next faced with the challenge of legitimising their own governance. This they accomplished again with reference to European precedent, adapted to their own needs. King George III was replaced by his secular stand-in, President George Washington. However, to avoid the very pitfalls that had catalysed the Revolution in the first place, the Founding Fathers aimed to delineate clear responsibilities and powers through the use of an explicit, written law of higher character than ordinary law. The resultant United States Constitutional system, enhanced by the federal precedent Marbury v. Madison (1803), insisted upon formalised mechanisms, such as judicial review to protect constitutionally-granted rights and liberties, thus introducing not only a founding body of law but also the means by which that body of law gained normative precedence. Once again, such a development in some ways

\footnotetext{
${ }^{270}$ Hamilton, Alexander, Federalist No. 16, in Hamilton, Madison, and Jay (1961), The Federalist Papers, 117.

${ }^{271}$ Hamilton, Alexander, Federalist No. 84, in Hamilton, Madison, and Jay (1961), The Federalist Papers, 514.

${ }^{272}$ See Footnote 271.
} 
jettisoned existing European ideas (such as the Lockean model of God-as-resistance), while adapting others, such as Coke's superiority of 'artificial reason' over 'natural reason.' Ultimately, networks and connections across the Atlantic amounted to a hoard remaking traditional understandings of constitutionalism. ${ }^{273}$ Regardless its substance, by the early nineteenth century, the United States Constitution was established as the normative, precedential body of law in the fledgling United States of America. Having been influenced by Europe, America was, through this development, able to turn the tables, and itself influence the Old World, while Europe itself went through a major period of transition.

\section{Legal Transition of Philosophical Truths}

The American Revolution had brought about a Novus Ordo Seclorum on one side of the Atlantic. Continental Europe's 'new order of ages', which would establish both normativity and precedence, roughly coincided with the same period. The starting point for this new order, though, was totally different from that of the American colonies, as were many of the assumptions and processes that would shape it.

In 1827, the German poet and playwright Johann Wolfgang von Goethe lyricised the existence of America in his poem Den Vereinigten Staaten (To the United States):

America, you are better off than

Our continent, the old.

You have no castles which are fallen,

No basalt to behold.

You're not disturbed within your innermost being,

Right up till today's life

By useless remembering

And unrewarding strife. ${ }^{274}$

Goethe's verse is, however, less praise of the United States, so much as a lament of Europe's 'historical baggage' - the 'fallen castles' and perpetual 'strife' that would colour any radical shift to a new era. Goethe himself had been a witness to this roughly three decades earlier, as the newly-minted French Republic began its

\footnotetext{
${ }^{273}$ Cf. Müßig (2017).

${ }^{274}$ Goethe, Johann Wolfgang von (1948), “The United States”, in The Permanent Goethe, ed. Mann, 655. Cf. the original German: Goethe, Johann Wolfgang von (1842), "Zahme Xenien: Den vereinigten Staaten", in Goethe, Nachgelassene Werke, vol. XVI, 96.
} 
own constitutional experiment, similar yet distinct to that begun by Washington, Madison, Hamilton, and the American constitutionalists.

The critical, formative years of this experiment were between the Years III and VIII (1794/5-9/1800); this period marked the interval between the establishment of the Directorate and its apotheosis into Bonaparte's single rule. ${ }^{275}$ The National Convention (Convention nationale $=l a$ Convention), ${ }^{276}$ as the first French assembly elected by a suffrage without class distinctions, set forth the draft of the radical democratic 'Jacobin' or 'Mountain' Constitution of the Year I (Acte constitutionnel du 24 juin 1793), ${ }^{277}$ which planned to wipe out the monarchy. In the following eight months (from autumn 1793 to spring 1794) these radical democratic ambitions were discredited by the Terror of the Committee of Public Safety (comité de Salut public) under the auspices of Maximilien de Robespierre ${ }^{278}$ and his Jacobins. During the Thermidorian ${ }^{279}$ constitutional debate, the majority of the members of the Convention (conventionnels) had no intention whatsoever to bring the Jacobin constitution of 1793 into force. With the beginning of the Parisian sansculottes insurrection on 1 Prairial III (20 May 1795), which resulted in the storming of the Convention with the battle cry 'bread and the constitution of 1793', the

\footnotetext{
${ }^{275}$ Particular attention to the Polish, Belgian, and Italian case studies can be found in vol. I of the ReConFort proceedings, Müßig (ed.) (2016).

${ }^{276}$ The National Convention was a constituent assembly that gathered between 20 September 1792 and 26 October 1795, when it was disbanded. Together with the Constituante, the Convention was addressed by Sieyès as a 'primary assembly.'

${ }^{277}$ The Jacobins, centred on the Society of Friends of the Constitution, was the driving political force behind the revolutionary government, and was divided between the moderate Girondins and the radical Mountain faction, headed by Robespierre. The enacting of the Constitution of the Year I marked the consolidation of the Mountain as the dominant faction within the Jacobin Club (hence the interchangeability of the term 'Jacobin' or 'Mountain' to with regards the constitution). See, for example, McPhee (2012), 152-5.

${ }^{278}$ Maximilien François Marie Isidore de Robespierre (1758-94): Arguably the most famous of the French Revolutionaries, and a symbol of its excesses, Robespierre was born in 1758 in Arras, though by the time the Revolution he had considerable influence in the capital; as a result, he was elected to the National Convention as a Parisian deputy in 1792. As a member of the Constituent Assembly he had maintained his political independence, though he was soon associated with the Montagnard (Mountain) faction of the Jacobin Club. His growing notoriety led to Girondist deputies accusing him of aspiring to dictatorship. He was also accused of being responsible for a massacre in the prisons of Paris. This only emboldened Robespierre, and he rose to the leadership of the Mountain. The ultimate responsibility for the execution of King Louis XVI fell to him; following this, in 1793, he politically crushed the Girondins, before beginning the Terror in order to destroy them totally. As the president of the Committee of Public Safety, the zenith of his power came with the trial and execution of his major political rivals Hérault de Séchelles and Robert Danton. Yet this notoriety also made him a target; just months after Danton and Séchelles' deaths, Robespierre was deposed, arrested on the orders of the National Convention, and sent to the guillotine. Thomas (1915), 2070-1.

${ }^{279}$ The adjective 'Thermidorian' refers to 9 Thermidor Year II (27 July 1794), when Robespierre and his radical co-revolutionaries came under concerted attack in the National Convention. It also describes the constitutional discourse in the National Convention (also known as the Thermidorian Convention) until the introduction of the Directory.
} 
willingness to promulgate the implementing laws (lois organiques) for the enforcement of the Mountain Constitution faded. It was only after Robespierre's fall that the National Convention could turn to the "commission of the eleven" 280 to formulate a new constitution. The eleven commissioners proposed the Directory Constitution of the Year III (1795), which passed on 22 August 1795 (5 Fructidor of the Year III). ${ }^{281}$ Its pillars were the return to the 1791 constitution, the affirmation of equality within the limits of civil equality, and the ruthless protection of the Republic against any legislative omnipotence or executive dictatorship. Similarly, protection was needed against the revolutionary subversive ghost of the faubourg Saint-Antoine, ${ }^{282}$ bordering the Bastille. The bicameral legislature was composed of the Council of Five Hundred, with its right to legislative initiative, and of the Council of Ancients (sometimes referred to as the Council of Elders; Conseil des Anciens), whose 250 deputies accepted or rejected proposed bills. Crucially, the executive power in the hand of five directors ${ }^{283}$ was vested in an executive college as the Committee for Public Safety had been. Thus, even if concentration of executive power was to be avoided by the re-election of one of the directors each year within the five-year term, the Directory still retained great power. This included emergency powers to curb freedom of the press and freedom of association.

\subsection{Sieyès' Constitutional Jury (jury constituionnaire)}

In this discursive context, the task of legally protecting the Revolution, from itself as well as outsiders, fell to Emmanuel Joseph Sieyès (1748-1836), the Roman Catholic abbot and political theorist whose 1789 pamphlet Qu'est-ce que le tiersétat? (What is the Third Estate?) had become the French Revolution's guiding manifesto. Sieyès proposed the introduction of a constitutional jury whose

\footnotetext{
${ }^{280}$ On 29 Germinal III (18 April 1795). The commission member were: Antoine-Claire Thibaudeau, Louis-Marie de La Révellière-Lépeaux, Denis Toussaint Lesage (d'Eure-et-Loir), François-Antoine Boissy d'Anglas, Jacques-Antoine Creuzé-Latouche, Jean-Baptiste Louvet de Couvray, Théophile Berlier, Pierre-Claude-François Daunou, Jean-Denis Lanjuinais, Pierre-Toussaint Durand de Maillane, Pierre-Charles-Louis Baudin (des Ardennes).

${ }^{281} \mathrm{Cf}$. in regard to the Constitution of the Year III: Mathiez (1934); Lefebvre (1943); Brunel (1985), 687-96; Pertué (1989), 284-6; Troper (1996); Bart et al. (eds.) (1998); Conac and Machelon (eds.) (1999); Luzzatto (2001); Troper (2006).

${ }^{282}$ The so-called Réveillon riots (affaire Réveillon) was one of the first violent upheavals of the French Revolution, and took place between 26 and 29 April 1789. The target was Jean-Baptiste Réveillon's factory in the St. Antoine district of Paris, which produced luxury wallpaper. Facing the pre-revolutionary economic crisis, Réveillon had responded to it by cutting workers' wages, while at the same time calling for the reduction of royal taxes. As a result, the workers demonstrated in front of the Hotel de ville, with the catch-cry of 'the bread for two pennies' (Le pain à deux sous).

${ }^{283}$ The Directors were chosen by the Council of the Ancients, from the list presented by the Council of Five Hundred.
} 
juridical-political competences comprised the adjudication of complaints, even by individuals, regarding constitutional infringements by constituted powers, ${ }^{284}$ reform and review of the Constitution itself every ten years. It also included, rather uniquely, an equitable jurisdiction as 'court for human rights ${ }^{\text {,25 }}$ if asked by official judicial referral of ordinary courts. This supplementary constitutional equity was based on natural law (most likely reflecting the character of 1789 Declaration of the Rights of Man and Citizen) and planned to be accessible if courts declared themselves unable to reach a decision in the absence of an applicable positive law or if they held the decision according to the legal text to be against their conscience. ${ }^{286}$

Sieyès' proposal was put forward at a time when normativity and constitutional precedence were very hard to establish. During the Revolution, the constitution was primarily conceived as a mean to guarantee the organisation of the powers and their functions. As Michel Pertué has demonstrated, the Revolution 'refused always to convey to any institution outside the legislative body the competence to verify and to guarantee the democratic process of the legislation and its conformity with the laws, the principles of the declaration of rights of man and citizen and with the constitution.' The dominant légi-centrisme was, in Pertué's reading, the Rousseauist understanding of law as the expression of the volonté générale, immunising the sovereign legislative assembly against the obligation to follow superior rules. ${ }^{287}$ Unsurprisingly, then, Sieyès' draft was rejected unanimously, but the course of debates illustrates decisive milestones of the French constitutional 'belief' after $1789 .^{288}$

It goes without saying that, in the unpreceded constitutional debates in Revolutionary France, nominalist certainty or even autonomy of constitutional semantics was an illusion. Yet, as the ReConFort project with its functional approach has consistently demonstrated, there was and is a mutual interdependency between the artifice or constituent making of a constitution and the discourse of public opinion and understanding. ${ }^{289}$ With this in mind, the debates in the National Convention on the 2 and 18 Thermidor Year III (20 July and 5 August 1795) are crucial not only for the understanding of French constitutional history. More expansively, they are vital for determining whether there is a common European core of normativity and precedence or whether modern European integration, though built since the grounding treaties as legal community, has ignored or not been fully aware of different national concepts of constitutional normativity and precedence. ${ }^{290}$

\footnotetext{
${ }^{284}$ Bastid, Paul (1939), Les Discours de Sieyès, 32.

${ }^{285}$ Bastid, Paul (1939), Les Discours de Sieyès, 42.

${ }^{286}$ Bastid, Paul (1939), Les Discours de Sieyès, 46-7.

${ }^{287}$ Pertué (2003), 46. Cf. also Maus (2006), 665.

${ }^{288} \mathrm{Cf}$. especially the first version of the speech of 2 Thermidor III in Bastid, Paul (1939), Les Discours de Sieyès, 18-20.

${ }^{289}$ Cf. Müßig, “Juridification by Constitution”, in Müßig (ed.) (2016), 3.

${ }^{290}$ Elsewhere, I have addressed the methodological naïveté regarding the European Court of Justice, which, very broadly speaking, evolves between a continental court style and a common law precedence manner. Seif (=Müßig) (2003a), 1-23.
} 
In contrast to the American recourse to the feudal-medieval common law right to resistance and the British reasoning of supreme parliamentary wisdom, the French starting point of 1789 was completely different. Judges had been figures of privilege within the Ancien Régime, which made them most suspicious for the revolutionaries. At the same time, they enthusiastically adopted the dogmatic concept of the supreme general will by Jean-Jacques Rousseau. In conflating the two the revolutionaries 'invented' the French aversion to having the acts of sovereign legislative assemblies controlled by judges. ${ }^{291}$ This suspicion continues today; modern French constitutional discourse does not speak of judiciary power (pouvoir), but of judiciary authority (authorité). Freedom by (fraternal-political) equality (liberté, egalité, fraternité), according to their condensation in Art. 6 Declaration of the Rights of Man and Citizen, had the consequence that the veritable counter-power remained with the French people (Art. 2 and 14 Declaration), represented a priori in the constituent assembly and thus entrusting the constituted legislative assembly with supreme legitimisation.

As the preeminent theorist of the national constituent sovereignty of the nation, ${ }^{292}$ and as a major contributor to the September Constitution (1791), Sieyès had gone into hiding during the Terror, before he reentered the political stage in the national convention after 9 Thermidor II (27 July 1794) with his intention, stronger as with other thermidoriens, to "finish the revolution. ${ }^{293}$ In this pragmatic constitutional thinking the constitution was the legal mean to reach this goal. Therefore the draft of a constitutional jury of the 18 Thermidor $\mathrm{III}^{294}$ was meant as part of the legal instruments to end the Revolutionary Terror. ${ }^{295}$ When the work of the 'commission of the eleven' had nearly finished, Sieyès, who was not one of the eleven, presented his draft on the constitutional jury in the constitutional debates of 2 and 18 Thermidor III (20 July and 5 August 1795).

By his concept of national sovereignty, Sieyès had been the first to differentiate the constituent power from the constituted power, in order to explain the decisive process of juridification of sovereignty. ${ }^{296}$ Concluding from his paradigms that the

\footnotetext{
${ }^{291}$ Cf. among others Ky (1926); Sueur (1989); Nicolle (1990); Morabito (2002), 117ff.; Laquièze (2003), 85-102; Maus (2003), 713ff.; Fioravanti (2007); Mestre (2010). Fioravanti's work refers to several Italian authors who have contributed extensively to the discourse surrounding the Constitution. I have benefitted from these contributions largely as a result of Fioravanti's extensive notes. Cf. Di Donato, (2004, 2005); Battaglini (1957); Cappelletti (1968). More recently, Luigi Lacchè (2000-2002), 41-93, (2016), 259-302.

${ }^{292}$ Cf. Müßig, "Juridification by Constitution”, in Müßig (ed.) (2016), 18-19.

${ }^{293} \mathrm{Cf}$. the title of Michel Troper's monograph Terminer la Révolution, La Constitution de 1795 (2006).

${ }^{294}$ 'DU JURY CONSTITUTIONNAIRE (AN III)', Archives Nationales 284 AP 4 doss. 8. This is also reproduced (in its original French) in Pasquino (1998), Sieyès et l'invention de la Constitution en France, 193ff. and Bastid, Paul (1939), Les Discours de Sieyès, 30-47. This, as well as an English translation, appear in this volume in Appendices A and B.

${ }^{295}$ Bronislaw Baczko, "Le contrat social des Français: Sieyès et Rousseau", in Baczko (1997), 332-3, cf. also Baczko (1989), 13ff.

${ }^{296} \mathrm{Cf}$. at length Müßig, "Juridification by Constitution”, in Müßig (ed.) (2016), 18ff.
} 
will of the nation itself is always lawful and that it is the law in itself, Sieyès established the inviolability of the constitution against the (constituted) legislative body. The exclusion of any absolutistic political power on the basis of the immanent differentiation of ordinary legislative bodies from constituent assemblies led to a 'superlegality of the constitution' (superlégalité de la constitution). ${ }^{297}$ If the legislative power could not 'without contradiction and absurdity touch the constitution' ('sans contradiction et sans absurdité toucher à la Constitution'), as Sieyès wrote in his report of the third estate (Compte rendu de Qu'est-ce que le tiers état?), ${ }^{298}$ this necessarily implied the existence of a control institution.

Though he was a moderate Jacobin of the Girondin faction, for which he was persecuted during Robespierre's Mountain-led Terror, at no point did Sieyès consider accommodation with monarchists of any stripe. He dismissed attempts by the Friends of the Monarchist Constitution (Les amis de la Constitution Monarchique) to reconcile pre-constitutional monarchical prerogative with the Revolution's stated principle of the rights of man and the sovereign nation, and insisted on the a priori undivided sovereignty of nation which brought forth the constitutional monarchy as constituted power just as the ordinary legislative assembly. ${ }^{299}$ This constitutional liberalism, ${ }^{300}$ built on the differentiation between constitution and ordinary legislation, left the door ajar for a guardian of the constitution, with the explicit function of declaring statutory law to be unconstitutional and the ability to overrule it, without this guardian being necessarily conceivable as judicial body. Taking into account the centrality of Rousseau's 'general will' in Revolutionary ideology, combined with the distrust against any 'heirs' of the noblesse de robe, Sieyès did not propose that his drafted constitutional jury would consist of professional judges, but of former members of the constituent assemblies, the legislative bodies, or the Convention. ${ }^{301}$

\footnotetext{
${ }^{297}$ Pasquino (1998), Sieyès et l'invention de la Constitution en France, 94.

${ }^{298}$ Compte rendu de Qu'est-ce que le tiers état? (1789), Archives Nationales 284 AP 4 doss. 8. Cited also in Pasquino (1998), Sieyès et l'invention de la Constitution en France, 168.

${ }^{299}$ During the trial of Louis XVI before the National Convention, Sieyès was among the 361 deputies who voted for the king's execution. According to some contemporary sources, it was Sieyès' vote that convinced others to similarly vote for death, and he is reported to have said merely 'I am for death!' See Johnson (1812), An impartial History of Europe, vol. II, 305.

${ }^{300}$ For Sieyès' constitutional theory, cf. among others Bredin (1988); Rjals (1991), 123-38; Pasquino (1998), Sieyès et l'invention de la Constitution en France; Tyrsenko (2000), 27-45; Troper (2001), 265-282; Jaume (2002), 199-221; Michel Troper, "La suprématie de la constitution et le jury constitutionnaire", in Troper (2006), 199-221.

${ }^{301}$ Arts. II-IV Draft of the Constitutional Jury (Year III); see Appendices A, B.
} 


\title{
6.1.1 Constitutional Debates of 2 and 18 Thermidor III (20 July and 5 August 1795)
}

Sieyès' prevailing motive in his interventions before the convention on 2 and 18 Thermidor III (20 July and 5 August 1795) was to reconcile constituent power-as he had established six years earlier in What is the Third Estate?-with a subordinate authority to control the constitutionality. The constitutional jury proposal followed the logic which began 1789 with the differentiation between the constituent and the constituted power. ${ }^{302}$ On the 2 Thermidor III (20 July 1795) Sieyès presented his ideas on the government and the political constitution:

\begin{abstract}
In regard to the government and the constitution, unity on its own means despotism, and division on its own means anarchy. Division with the unity gives social guarantee, without which liberty would be only precarious [...] Divide, for hindrance of despotism; centralise for avoiding the anarchy [...] I only know two systems of the division of powers: equilibrium and competition, or in nearly similar terms, the system of counter-powers and of organised unity. ${ }^{303}$
\end{abstract}

In response to the Jacobin argument that the representative system was anti-democratic (expressed among others by Hérault de Séchelles and Maximilien de Robespierre), Sieyès employed a celebrated, though prosaic, metaphor of the post. Denying representation would be the same as 'to reserve the right to carry your letters yourself without trusting them to the public establishment [the post office] in charge of conveying them. ${ }^{304} \mathrm{He}$ concluded by demanding the institution of a constitutional jury, a political organ more than a juridical one: 'This is the real body of representatives which I demand, with a special mission to judge the reclamations against every infringement onto the constitution. ${ }^{305}$

In the discourse of 18 Thermidor III (5 August 1795), Sieyès explained the attributions and the organisation of the constitutional jury, organised according his draft in seventeen articles ${ }^{306}$ and charged with the control over the legislature about the respect of the constitution: 'The necessity of a constitutional jury', Sieyès asserted in front of the National Convention,

\footnotetext{
${ }^{302}$ Cf. also Fauré (1999), 29.

${ }^{303}$ Sieyès, Emmanuel Joseph (1795), Moniteur, 2 Thermidor III, 1236: 'En fait de gouvernement, et plus généralement en fait de constitution politique, unité toute seule est despotisme, division toute seule est anarchie. Division avec unité donne la garantie sociale, sans laquelle toute liberté n'est que précaire. [...] Divisez, pour empêcher le despotisme; centraliser, pour éviter l'anarchie. [...] Je ne connais que deux systèmes de division des pouvoirs: le système de equilibre et celui de l'unité organisée.'

${ }^{304}$ Sieyès, Emmanuel Joseph (1795), Moniteur, 2 Thermidor III, 1236. Cf. also Lescuyer (2001), 355.

${ }^{305}$ Sieyès, Emmanuel Joseph (1795), Moniteur, 2 Thermidor III, 1237.

306، Je demande d'abord un jury de Constitution, ou, pour franciser un peu plus le mot de jury, et le distinguer dans le son de celui de juré, une jury constitutionnaire.' Emmanuel Joseph Sieyès, "Opinion de Sieyès sur les attributions et l'organisation du jury constitutionnaire proposé le 2 thermidor, prononcée à la Convention nationale le 18 du même, l'an III de la République", Moniteur, 18 Thermidor III, 1311.
} 
forms a sort of preliminary question; it does not suffer from difficulty. How in fact could the preview of the legislator accustom itself to the idea of an abandoned constitution, in the very moment of its coming-into-existence? A constitution is a body of obligatory laws or it does not exist; if it is body of laws, one asks oneself where is the guardian, where is the magistrate of this code. ${ }^{307}$

The constitutional jury, or the 'depository keeper of the constitutional act'/ dépositaire conservateur de l'acte constitutionnel, as it was named by Sieyès in Art. I of his proposal, 'is to be composed of 108 members, a third of them renewed every year, in the same period as the legislative body' (Art. II). ${ }^{308}$ 'The first formation of the constitutional jury', the draft proposed, 'is constituted by the convention by means of a secret ballot, in the manner that a third of its members is chosen among those of the constituent assembly [la Constituante], another third among the members of the legislative, and the last third among the members of the Convention [la Convention]' (Art. IV). ${ }^{309}$ It also stipulated that 'the 36 newcomers each year are to be chosen by the jury itself among the 250 members who have to leave the one or the other of the two councils of the legislative bodies' (Art. III), ${ }^{310}$ '[t]he sessions of the constitutional jury will not be open to the public' (Art. V), ${ }^{311}$ and 'the decisions of the constitutional jury will bear the name "decision" [arrêt].' (Art. VII). ${ }^{312}$

According to Sieyès' 'opinion about the attributions and the organisation of the constitutional jury', the jury had three functions. The first competence was to safeguard the Constitution by functioning as a supreme tribunal for the constitutional order (tribunal de cassation dans l'ordre constitutionnel). ${ }^{313}$ The second was to perfect the constitution by presenting projects of constitutional revision as an atelier de propositions pour les amendemens. ${ }^{314}$ The third prerogative of the jury was the most inventive one: it was an equitable constitutional jurisdiction on the basis of natural law as supplement de juridiction naturelle, if judgements could not

\footnotetext{
${ }^{307}$ Sieyès, Emmanuel Joseph (1795), “Opinion de Sieyès”, Moniteur, 18 Thermidor III, 1311.

${ }^{308}$ 'They consist of 108 members, a third of whom are annually replaced, and at the same time as the legislative body'/II est composé de cent huit membres, qui se renouvelleront annuellement pariers, et aux mêmes époques que le corps législatif.

${ }^{309}$ La première formation du jury constitutionnaire se fera au scrutin secret par la Convention, de manière qu'un tiers des membres soient choisis parmi ceux de l'assemblée nationale, dite Constituante, un autre tiers parmi ceux de l'assemblée législative, et un autre parmi les membres de la Convention.

${ }^{310}$ L'élection du tiers ou des trente-six entrants se fait par le jury constitutionnaire lui-même, sur les deux cent cinquante membres qui doivent, à la même époque annuelle, sortir de l'un et l'autre conseil du corps législatif.

${ }^{311}$ Les séances du jury constitutionnaire ne seront point publiques.

${ }^{312}$ Les décisions du jury constitutionnaire porteront le nom d'arrêt. The original French-arrêtmost accurately translates to the English 'judgement'. However, in modern terminology, 'judgement' refers to the first instance jurisdiction', especially in the French context. The modern usage of the term 'decision' is closer to Sieyès' intention.

${ }^{313}$ Sieyès, Emmanuel Joseph (1795), “Opinion de Sieyès”, Moniteur, 18 Thermidor III, 1311.

${ }^{314}$ See Footnote 313.
} 
be issued by ordinary courts due to lacking or to unjust positive law. ${ }^{315}$ None of these functions could be exercised on the jury's initiative itself (Art. XVII). ${ }^{316}$

\section{'Jury de Cassation'}

The first function of controlling constitutionality was very complex, due to the Rousseauist preference for supreme legislative legitimacy. The acts that fell under the jury's control, according to Sieyès' plans, were the acts of the legislative councils (the Council of Five Hundred and the Council of Ancients), unconstitutional acts regarding matters related to ballots, unconstitutional acts of the primary assemblies, and those of the court of cassation. Art. VIII of the Sieyès project provided for the annulment of unconstitutional legislative acts: 'The acts declared as unconstitutional by the decision of the constitutional jury are null and void. ${ }^{317}$ In any case, the jury could never declare acts to be unconstitutional on its own initiative, but only if asked to do so by any applicant entitled according to Art. VI of the draft: 'The constitutional jury will comment on the violations or the impairments of the Constitution, which will be denounced to them, against the acts, either by the council of ancients, or by the council of five hundred, or by the electoral assemblies, or by the primary assemblies, or by the tribunal of cassation. ${ }^{318}$ Any minority out of the said constitutional bodies and even individual citizen could bring such a denunciation forward. ${ }^{319}$ The jury de cassation had the legal function of a supreme constitutional court, annulling acts contrary to the fundamental law. ${ }^{320}$ It was the expression of a particular vision of the separation of powers, ${ }^{321}$ and assured 'the permanent political relevance of a revolutionary impact finds itself beyond the year III. ${ }^{, 322}$

\footnotetext{
${ }^{315}$ See Footnote 313.

${ }^{316}$ 'The constitutional jury cannot issue any decision by its own initiative.' /Le jury constitutionnaire ne peut rendre aucun arrêt du propre mouvement.

${ }^{317}$ Les actes déclarés inconstitutionnels par arrêt du jury constitutionnaire, sont nuls et commenon avenus.

${ }^{318}$ Le jury constitutionnaire prononcera sur les violations ou atteintes faites à la constitution, qui lui seraient dénoncées contre les actes, Soit du conseil des Anciens, Soit du conseil des CinqCents, Soit des assemblées électorales, Soit des assemblées primaires, Soit du tribunal de cassation.

${ }^{319}$ Art. VI of the project continues 'When these denunciations will be addressed to them, by the council of ancients, or by the council of five hundred, or individually by the citizens, they adjudicate on a similar denunciation addressed to them by the minority against the majority of one or another of the constitutional bodies mentioned above.'/Lorsque ces dénonciations lui seront portées, Soit par le conseil des Anciens, Soit par le conseil des Cinq-Cents, Soit par des citoyens en nom individuel, II prononcera sur semblable dénonciation qui lui serait portée par la minorité contre la majorité de l'un ou l'autre des susdits corps constitués.

${ }^{320}$ Fioravanti (2007), 87-103.

${ }^{321}$ Pasquino (1998), Sieyès et l'invention de la Constitution en France, 13.

${ }^{322}$ Morabito (2002), 117.
} 
Sieyès' proposal to establish a constitutional jury contributed-beyond the control of the constitutionality of laws - in an original manner to a transition of the concept of a constitution as mechanism, as the simple distribution of powers, to a constitution as an obligatory rule, supreme above all the others. ${ }^{323}$ The consequence of this 'super-legality ${ }^{, 324}$ of the Constitution was the possibility to annul unconstitutional acts. ${ }^{325}$ For Sieyès' contemporaries, though, Paul Bastid identifies 'an incontestable confusion. ${ }^{, 326}$ Michel Troper has substantiated the probable source of this confusion, noting that the majority of acts addressed as 'unconstitutional' in section one of Art. VI of the project were neither laws nor necessarily legislative acts of the two branches of the legislative body under the Directorate, and therefore unconstitutionality is hard to imagine. ${ }^{327}$ The conventionalists as a whole were averse to establishing a power of superior control of that of the legislative assemblies: 'Due to their preference for the predominance of the law,' writes Marcel Morabito, 'the revolutionary exaltation of the representation remained incompatible with any idea of controlling the constitutionality. ${ }^{, 328}$ For them, the constitution of 1795 provided internal guarantees to protect itself: firstly, by the separation between the councils and the executive power and, secondly, by the fact that the Council of the Ancients could exercise its own control of constitutionality; it could refuse its approval for the acts taken by the council of 500 due to the disrespect for the formes and proceedings previewed in the constitution (Art. 88 of the Directory Constitution 1795). ${ }^{329}$

\section{'Jury de Proposition’}

The mastermind of French national sovereignty planned his constitutional jury not only to be the 'guardian and defensor of the constitution', ${ }^{330}$ but attributed to the control organ the mandate to improve and perfect the Constitution and the Declaration of the Rights of Man and Citizen, responding to new developments and societal changes. ${ }^{331}$ This was meant to restrain the Revolution and to control the a priori unlimited pouvoir constituant, represented in 1789 by the French nation, which Sieyès' pamphlet What is the Third Estate? declared 'to be the supreme

\footnotetext{
${ }^{323}$ Clavreul (1982), 163: 'Le jury constitutionnaire exerçait une garantie de la légalité du système de normes.'

${ }^{324}$ Pasquino (1998), Sieyès et l'invention de la Constitution en France, 12.

${ }^{325}$ Papatolias (2000).

${ }^{326}$ Bastid, Paul (1970), Sieyès et sa pensée, 436: 'Un incontestable désordre.'

${ }^{327}$ Michel Troper, "Sieyès et le jury constitutionnaire", 273.

${ }^{328}$ Morabito (2002), 118.

${ }^{329}$ Cited according to Willoweit and Seif (=Müßig) (2003), 364.

${ }^{330}$ Schmitt, Carl (1931) Der Hüter der Verfassung, 1; Schmitt, Carl (1929) "Der Hüter der Verfassung", Archiv des öffentlichen Rechts XVI, 161.

${ }^{331}$ Azimi (1998), 199-221.
} 
master of any positive law. ${ }^{, 32}$ The revision competence of the jury was a disciplinary restriction of the constituent power. In the words of Michel Pertué, ${ }^{333}$ 'the constituent power attributed to the nation in 1789 by Sieyès [as an] unconditioned and unlimited [one] became regulated and more and more restricted in the hands of the constitutional jury of the year III (1795), and afterwards in the hands of the college of conversators of the Consulate Constitution of the Year VIII (Constitution de l'an VIII/1799). ${ }^{334}$ The challenge to be tackled by the spiritus rector of the constituent sovereignty and its different uniqueness compared to the constituted sovereignty was to bring the constituent power under the legal regime of the normative constitution, without eliminating the differences to the constituted powers. ${ }^{335}$ Whereas the latter act only according to the norms of the positive law, the domain of the constituent power is the natural law. To bridge this gap, Sieyès intended a periodical progressive amendment of the Constitution by the jury. The constituent power could then rest with the people, but as a regulated one. In the midst of the discourse of 18 Thermidor III (5 August 1795), which dealt with the rights of future generations, Sieyès claimed the unquestionable right of future generations to make their own constitutional amendments that 'the authentic motives of a political constitution rest with the nation, and especially with the generation which has passed it.' This singularity of the Constitution's origins led, in Sieyès' words, to 'the legal need to provide our constitution with the principle of unlimited perfection, which allows for concession to the needs of every epoch but never for any possibility of a total reproduction or destruction, neither an abandonment by hazard. ${ }^{336}$

\footnotetext{
${ }^{332}$ 'Le maître suprême de tout droit positif.' Sieyès (1970), 183. Sieyès continues: 'Une nation est indépendante de toute forme; et de quelque manière qu'elle veuille, il suffit que sa volonté paraisse pour que tout droit positif cesse devant elle comme devant la source et le maître suprême de tout droit positif.' Sieyès, Emmanuel Joseph (1970), Qu'est-ce que le Tiers état?, 183.

${ }^{333}$ Pertué (1976), 417.

${ }^{334}$ Adopted on 24 December 1799, the Consulate Constitution established the Consulate and General Napoleon Bonaparte as first consul. After the coup of 18 Brumaire (9 November 1799), this created a statutory justification for the concentration of supreme power in Bonaparte's hands, paving the way for his accession to emperor in 1804. Both 18 Brumaire and the application of the Consulate Constitution are considered the end points of the French Revolution.

${ }^{335}$ On the constituent power cf. in addition to the literature cited in ReConFort I, ed. Müßig (2016), 83ff.; Klein (1996); Negri (1997); Bockenförde (2000); Troper (2003), 101-11; Le Pillouer (2005); Cayla (2006), 249-65.

${ }^{336}$ Sieyès, Emmanuel Joseph (1795), "Opinion de Sieyès”, Moniteur, 18 Thermidor III, 1312. The whole quote reads: 'Au surplus, sans vouloir disputer aux générations futures le droit de faire à cet égard, tout ce qui leur conviendra, il est permis, et c'est encore un devoir de remarquer que les véritables rapports d'une constitution politique sont avec la nation qui reste, plutôt qu'avec telle génération qui passe; avec les besoins de la nature humaine, communs à tous, plutôt qu'avec des différences individuelles. Ces considérations nous font une loi de donner à notre acte constitutionnel, ainsi qu'on vient de le dire, un principe de perfectionnement illimité, qui puisse le plier, l'accommoder aux nécessités de chaque époque, plutôt qu'une faculté de reproduction ou de destruction totale, abandonnée au hasard des événements.'.
} 
As the constituent sovereignty rested with the people, the jury could not directly intervene for constitutional reforms; its role was only to make propositions. To avoid popular unrest and upheaval during a period of constitutional reform, the jury had to present every ten years a notebook of constitutional amendments to the legislative councils and primary assemblies (Art. XI, section 1 and 2). ${ }^{337}$ The primary assemblies - reunited every year for the election of the people's representatives - could speak themselves in favour of or against the possibility to delegate a temporary constituent power to the actual legislature (Art. XII, section 1). ${ }^{338}$ 'If the majority of the primary assemblies said no,' the wording of the draft continued, 'the notebook with amendments will be seen as void and its propositions cannot be reproduced before the following tenth year' (Art. XII, section 2). ${ }^{339}$ Art. XII makes it furthermore explicit that the Council of Ancients, if delegated, had no power to make changes to the jury's propositions (section 3). ${ }^{340}$ Art. XIII limits the sessions of the council of Ancients exercising constituent power on the primary assemblies' mandate to twelve in total or to two in a decade (section 2). ${ }^{341}$ 'There will be, for the sessions of the constituent power, a separated written report, in a particular register, which will be, in the end, solemnly placed in the archives of the constitutional jury' (Art. XIII, section 3$){ }^{342}$ The particularity of

\footnotetext{
${ }^{337}$ Section 1: 'In the course of each tenth year, starting from year 1800, eight of the Republic, twelfth of the Revolution, the constitutional jury will examine again their opinions registered.' Dans le courant de chaque dixième année, à commencer de l'an 1800, huitième de la république, douzième de la révolution, le jury constitutionnaire examinera de nouveau ses avis consignés dans son registre. Section 2: 'They will create their notebook of propositions in order to improve the constitutional act, and they will officially communicate with the Council of Ancients and that of Five Hundred, in order to receive the greater publicity. This communication will be made three months at least before the primary assemblies are annually held.'/ll composera son cahier de propositions pour améliorer l'acte constitutionnel, Et il en donnera officiellement communication au conseil des Anciens et à celui des Cinq-Cents, afin qu'il reçoive la plus grande publicité. Cette communication se fera trois mois au moins avant la tenue annuelle des assemblées primaires.

${ }^{338}$ 'The primary assemblies will, after having read the notebook of propositions, declare yes or no, if they understand giving the council of Ancients the power to lay them down as rules.'/Les assemblées primaires, après lecture faite du cahier de propositions, déclareront oui ou non, si elles entendent donner au conseil des Anciens le pouvoir d'y statuer.

${ }^{339}$ Si la majorité des assemblées primaires a dit non, le cahier sera regardé comme non avenu, et ses propositions ne pourront être reproduites avant la dixième année suivante.

${ }^{340}$ 'If the majority of the primary assemblies said yes, the constituent power is delegated, by this fact only, to the Council of Ancients, to lay the propositions made down as rules without being able to either amend them or to substitute them with others.'/Si la majorité des assemblées primaires a dit oui, le pouvoir constituant est délégué, par ce seul fait, au conseil des Anciens, pour statuer sur les propositions faites, sans qu'il puisse ni les amender ni en substituer d'autres. ${ }^{341}$ 'Altogether, they cannot exceed the number of twelve nor that of two per decade.'/Elles ne pourront excéder le nombre de douze en tout, ni celui de deux par décade.

${ }^{342}$ II y aura, pour les séances du pouvoir constituant, un procès-verbal séparé, sur un registre particulier, qui sera, à la fin, solennellement déposé aux archives du jury constitutionnaire.
} 
the mandate with constituent power is highlighted in section 1 of the XIII, which declares 'the sessions to be exclusively affected., 343

\section{'Jury of Natural Equity'}

The third function of the jury was an equitable control — based in the natural lawof the judgements of the ordinary courts. Art. XIV section one of Sieyès' proposal provided that 'every year, at least one-tenth of the members of the constitutional jury, to be taken randomly, will build a jury of natural equity. ${ }^{344}$ This function of an equitable court could only be exercised 'on the official requests of different courts, for having a decision of natural equity in the case that the courts declare not having been able to judge, due to the absence of a positive law which can apply to that, or to being forced to judge only against their conscience, only according to the text of the law' (Art. XIV, section 2). ${ }^{345}$ These decisions of natural equity were to be enacted by the relevant tribunal that had made the request in the first place; the constitutional jury could also select other tribunals to enforce the decisions (Art. $\mathrm{XV}) .{ }^{346}$ They "will be officially communicated, within one month, to the Council of Five Hundred' (Art. XVI). ${ }^{347}$ In this way, Sieyès intended that the constitutional jury would function as a court of natural equity, if the ordinary courts identified or believed there to be loopholes or iniquities in positive law.

\subsubsection{Communicative Implications of the Jury's Attributions in the Thermidorian Constitutional Debates}

'Jury de Cassation'

In regard to the communicative interdependencies of constitutional debates, Sieyès' idea to control the constitutionality of ordinary laws addressed the precedence of constitution. For this legal function of the constitutional jury he relied on jury

\footnotetext{
${ }^{343}$ 'The sessions at which the council of ancients will exercise the constituent power will be exclusively assigned.'/Les séances où le conseil des Anciens exercera le pouvoir constituant y seront exclusivement affectées.

${ }^{344}$ Chaque année, le dixième au moins des membres du jury constitutionnaire, pris au sort, se formera en jury d'équité naturelle.

${ }^{345}$ Cette section sera, en sus des deux attributions précédentes, exclusivement chargée de prononcer sur les demandes officielles qui lui seraient portées par les divers tribunaux, à l'effet d'avoir un arrêt d'équité naturelle sur les cas qu'ils déclareraient n'avoir pu juger, faute de loi positive qui pût s'y appliquer, ou ne pouvoir juger que contre leur conscience, d'après le texte seul de la loi.

${ }^{346}$ Les arrêts d'équité naturelle seront exécutés par le tribunal qui aura formé la demande offcielle, ou par toute autre, au choix du jury constitutionnaire.

${ }^{347}$ Les arrêtés d'équité naturelle seront officiellement communiqués, dans le mois, au conseil des Cinq-Cents.
} 
members elected by citizens and having already sat in the legislative assemblies, in order to avoid any allusions to a formal court with professional judges. Like old wine in new skins, Sieyès referred back to the prerevolutionary parliamentary right of remonstrance in an attempt to convince his contemporaries of a long-standing French tradition of legally-restrained sovereignty. Literally borrowing from Montesquieu's praise of the French parlement in the Spirit of the Laws (II 4), ${ }^{348}$ the jurors are said to fulfill their conservative function 'with fidelity in the guard of the constitutional deposit' (avec fidélité à la garde du dépôt constitutionnel). ${ }^{349}$

The control of the constitutionality of laws was the attribute of Sieyès' planned jury that met with the most acceptance, especially as there were many other commutated proposals. As demonstrated by the research of Marco Fioravanti the Girondin Arman-Guy de Kersaint ${ }^{350}$ had already proposed a tribunal of censors to control the legislative and the executive in their accordance with the constitution. ${ }^{351}$ Condorcet had discussed popular veto as a means of protecting the citizens against legislative arbitrariness, ${ }^{352}$ which provided for the dissolution of the legislative assembly if the primary assemblies were against the legislative act. ${ }^{353}$ Also, the debate on the Mountain Constitution witnessed proposals to control the constitutionality of legislative acts. Chapter XV of the project of the Mountain Constitution included provisions for a 'national grand jury', though this was rejected. ${ }^{354}$

\footnotetext{
${ }^{348}$ Charles-Louis de Secondat, Baron de la Brède et de Montesquieu (1994), De l'Esprit des Lois, in Euvres complètes, vol. II, 247.

${ }^{349}$ Bastid, Paul (1939), Discours de Sieyès, 32.

${ }^{350}$ Armand-Guy Simon de Coëtnempren de Kersaint (1742-1793): Born in Paris (sometimes stated: Le Havre) to a noble family, Arman-Guy de Kersaint followed the example of his father by joining the French Navy at fourteen. He distinguished himself in action, and soon made a name for himself as a result of his bravery and skill. In spite of his upbringing, when the Revolution began he joined the Jacobin Club, and his ideas of social justice were influenced by Thomas Paine. A moderate Girondin, he became alarmed at the volatile direction of the Revolution under the influence of the Montagnard Jacobins; as a member of the National Convention, he voted against the king's execution and the rising tide of repression. Because of this, he fell under suspicion and, in 1793, was arrested, tried, and executed. Thomas (1915), 1433.

${ }^{351}$ Fioravanti (2007), 89 (n. 16).

${ }^{352}$ Marie Jean Antoine Nicolas de Caritat de Condorcet (1743-1794): The Marquis de Condorcet was born 1743 at Ribemont. He became a mathematician and philosopher and in 1782 was elected a member of the French Academy. Despite his aristocratic background, he was broadly in favour of liberalism and was politically active in this regard; he wrote in favour of American Independence, and published many political treatises. In 1791 he was deputed to the Legislative Assembly and in 1792 he became a member of the Constitution Committee. In 1793, his moderate credentials led to him being denounced as a Girondin, and he immediately went into hiding. In April 1794, he was discovered, arrested, and imprisoned. Rather than facing the guillotine, Condorcet instead took poison. Thomas (1915), 698; Fioravanti (2007), 89 (n. 17).

${ }^{353}$ Fioravanti (2007), 89 (n. 18).

${ }^{354}$ Fioravanti (2007), 89 (n. 19).
} 
Nevertheless, Marie-Jean Hérault de Séchelles, ${ }^{355}$ the main redactor of the Constitutional Act of 1793, positioned himself in favour of a protection against 'oppression by the legislative body', ${ }^{356}$ and found himself in the company of Robespierre. $^{357}$ All these proposals, together with le Balancier politique ${ }^{358}$ and the Articles proposés pour la réforme de la Constitution $1793,{ }^{359}$ accepted the superiority of a control organ not democratically legitimised and seemed to have prepared the path for the legal attribution of cassation of unconstitutional acts in Sieyès' drafted jury.

\section{'Jury de Proposition'}

For the revision competence, the communicative readiness was different. Fioravanti notes that the problem of constitutional revision was appreciated by the contemporaries of the Revolution, ${ }^{360}$ but none of them had Sieyès' clarity to differentiate the constituent process of juridification by constitution from the ordinary legislative proceedings within the constituted legislative assembly. Sieyès explained the revision or amendment function of the jury by contrasting it with the permanent subliminal dangers of revolutionary turmoil that could result from radical constitutional changes. As an incremental policy of reform, rather than one employing great leaps, Sieyès' constitutional jury would rely on decennial progressive amelioration to secure the Revolutionary acquis of 1791 against recidivism, but also against overruling. Sieyès did not want to see the convention, like a figure from old mythology, constantly reborn, because this would invite danger. 'Will we amuse ourselves by saying, like the phoenix, that it [the convention] will rise like a phoenix out of its ashes', he asked rhetorically. '[T]he rebirth of the phoenix is a chimaera and the periodical return of a convention can be a real calamity. ${ }^{361}$ The revision function of the proposed constitutional jury, however, would avoid the alternative solution of periodical conventions, which seemed to him at best naïvely utopian, and at worst dangerous. The proposed amendment, or more exactly the

\footnotetext{
${ }^{355}$ Marie-Jean Hérault de Séchelles (1759-1794): Born to an aristocratic family, Hérault de Séchelles worked as a lawyer. Joining the Jacobin Club on the advent of Revolution, he was elected to the Legislative Assembly in 1791, where he became the leader of the Jacobins. In 1793, the proscription of the Girondins led to his ascension to the presidency of the convention; in this role, he penned the "Constitution of 1793", and also joined the Committee of Public Safety. However, his political disagreements with Robespierre and his clear popularity and power made him a target of the Terror. Denounced by Robespierre, he was arrested and, along with Robert Danton, executed by beheading. Thomas (1915), 1268.

${ }^{356}$ Fioravanti (2007), 89 (n. 21).

${ }^{357}$ Fioravanti (2007), 89 (n. 20).

${ }^{358}$ Fioravanti (2007), 89 (n. 22).

${ }^{359}$ Fioravanti (2007), 89 (n. 23).

${ }^{360}$ Fioravanti (2007), 88-9 (n. 9-14).

${ }^{361}$ Bastid, Paul (1939), Discours de Sieyès, 38.
} 
proposed perfection of the Constitution, rewritten every ten years by the jury, was planned to be presented to the primary assemblies. The assembly members would then have the ability to grant or not to grant the legislative body the mandate to exercise constituent power, limited, in this case, to the simple acceptance or to the refusal of the proposition of the amendment. This was Sieyès' 'project of amelioration of the constitutional act' (projet d'amélioration de l'acte constitution$n e l) .{ }^{362}$ This complex procedure aimed, on the one hand, to involve the citizens in the process of revision and, on the other hand, to separate the responsible organs in charge of the revision's proposition and its ratification. By his plea for partial changes at regular intervals, Sieyès communicated the singularity of the constituent assembly: any repetition carried in itself the risk of radical transformation, a vocabulary far too familiar to the contemporaries of the Thermodorian debates.

\section{'Jury of Natural Equity'}

The idea of a 'natural jurisdiction as equitable supplement of the positive jurisdiction' (supplément de juridiction naturelle aux vides de la juridiction positive) ${ }^{363}$ was the attribution of the planned constitutional jury that challenged the contemporaries most. It raised the constitutional jury not only to an institutional standing as a court, but in doing so raised concerns that it was little more than a new edition of the 'arbitrary jurisprudence' of the Ancien Régime and its denounced cohorts of 'commentators and interpreters.' 364 Being inspired by the English common law, Sieyès had drafted the equitable function of the constitutional jury ${ }^{365}$ and tried to communicate its supplementary character by the prerequisite that cases could only be heard before it if they were officially referred to it by other courts. This would occur if these other courts declared themselves incapable of adjudicating, owing to the absence of applicable positive law, or if such judgement would occur contrary to the 'conscience' of the court, only according to the text of the law (exclusivement chargé de se prononcer sur les demandes officielles qui lui seraient portées par les divers tribunaux, à l'effet d'avoir un arrêt d'équité naturelle sur les cas qu'ils déclareraient n'avoir pu juger, faute de loi positive qui pût s'y appliquer, ou ne pouvoir juger que contre leur conscience, d'après le texte seul de la loi). ${ }^{366}$ Continental Europe had typically understood 'equity' to be equivalent to aequitas, and thus the purview of God. Mercy, in this understanding, was not just a category of human law but divine will. Therefore, by attributing equity to his constitutional jury, Sieyès presumed that the jury would hold supreme authority over the ordinary

\footnotetext{
${ }^{362}$ Bastid, Paul (1939), Discours de Sieyès, 39.

${ }^{363}$ Bastid, Paul (1939), Discours de Sieyès, 40.

${ }^{364}$ Gauchet (1995), 179.

${ }^{365}$ Fioravanti (2007), 94.

${ }^{366}$ Bastid, Paul (1939), Les Discours de Sieyès, 46-7.
} 
courts. ${ }^{367}$ This, however, could not be inferred; whereas Sieyès pretended a simple application of equity in the mere English correction manner, the vague character of natural equity was immediately assumed to be a pass for excessive, even arbitrary power. ${ }^{368}$

Analysing the Thermodorian debates, it is evident that this competence of natural equity enshrined in the proposed constitutional jury might well have been the decisive issue that led to its unanimous rejection on 25 Thermidor III (12 August 1795). ${ }^{369}$ All members of the Convention seemed to have gathered behind Antoine-Claire Thibaudeau, ${ }^{370}$ the Mountain deputy and former member of the Committee of Public Safety. Thibaudeau's speech before the Assembly on 24 Thermidor III (11 August 1795) ${ }^{371}$ was symptomatic of the dismissive atmosphere against the project of the constitutional jury. Thibaudeau opposed two models of 'limiting the power of the organs of the state' (limitation du pouvoir des organes de l'État - essentially, the models of 'rule' and 'balance'372 — when concluding the lack of utility of constitutional control. He preferred, as he suggested vividly, 'the liberal constitutionalism of the counterpowers.' Thibaudeau continued:

If one examines the result of their researches [that of the publicists which have been interested in the separation of the powers] one will see that they have found two types of means to contain the powers, the ones which are external for them and the others which are inherent for them [to the organization even of the powers]. Among the first ones, one can

\footnotetext{
${ }^{367}$ Müßig (2013b), 23-65.

${ }^{368}$ Troper, "Sieyès et le jury constitutionnaire", 281.

${ }^{369}$ Moniteur Universel, Reímpression de I'Ancien Moniteur (1842), vol. XXV, 489ff.

${ }^{370}$ Antoine-Claire Thibaudeau (1765-1854): Thibaudeau was born in 1765 to the family of a prominent lawyer in Poitiers. Admitted to the bar in 1787, he was an enthusiastic political activist; after accompanying his father to the Estates General in Versailles in 1789, he set up a local revolutionary club in Poitiers. In 1792 he was appointed to the National Convention, in which he - like Sieyès - voted for the execution of Louis XVI. In 1796 he rose to the presidency of the Council of Five Hundred. He maintained his prominence after the Republic departed along the imperial path. In 1808 he was elevated to the title of 'count', and supported Napoleon during the Hundred Days campaign in 1815, but went into exile upon his defeat, only returning after the July Revolution in 1830. Three and a half decades later, Napoleon's nephew, Napoleon III (Louis-Napoleon Bonaparte) would appoint him to the Senate. Thibaudeau died in 1854, having served under the Ancien Régime, the First Republic, the First Empire, the Second Republic, and the Second Empire. Thomas (1915), 2304.

${ }^{371}$ Thibaudeau's speech was reproduced in the Moniteur newspaper. He began by declaring: 'Sieyès avait imaginé, sous le nom de Jurie constitutionnaire, un corps de censeurs qui, supérieur à tous les pouvoirs, devait preserver la Constitution de toute atteinte et y proposer des reformes. Cette institution fut la seule partie de son projet prise en consideration. La commission voulut l'accommoder à son plan de Constitution et la proposa à la Convention. La jurie y trouva des défenseurs et des adversaires. Je la combattis (le 24 thermidor), et elle fut rejetée à la presqu'unanimité. Elle me parut une superfétation inutile et dangereuse.' Thibaudeau, Antoine-Claire (1795), Moniteur, 24 Thermidor III, 1239ff. (Reproduced in Moniteur Universel, Reimpression de l'Ancien Moniteur, vol. XXV, 484 and 487-9). Cf. also Thibaudeau Antoine-Claire (1824), Mémoires sur la Convention et le Directoire, 186.

${ }^{372}$ For the distinction between 'rules' and 'balance', see Manin (1989), 372-89.
} 
classify the appeal to the people, the censors, or any other body established for judging the infractions of the constitution. ${ }^{373}$

After rejecting the idea of the appeal to the people (l'appel au peuple), ${ }^{374}$ Thibaudeau examined the question posed at the assembly by Sieyès:

Let us now see if a body instituted above the public powers, for examining their acts, as he [Sieyès] proposes, is capable of guaranteeing their independence and integrity of the constitution, and I immediately pose myself this question: if the constitutional jury, the functions of which will be determined by the constitution, exceeds the limits thereof, who will suppress their usurpation?

According to Thibaudeau no answer could be found to the question who supervises the jurors:

I admit that I am searching for an answer but can't find anything satisfying [...] I would be justified in asking that supervisors be given to this jury and this gradual surveillance will be understood ad infinitum. Thus, [this reminds me of] the people of the Indies, they say that they commonly believe that the world is carried by an elephant and this elephant by a turtle; but when they arrive at asking on what the turtle rests, goodbye erudition. ${ }^{375}$

Subsequent to this criticism, Thibaudeau arrived at exposing his model of the 'guarantee of the limitation of the powers' (garantie de la limitation des pouvoirs):

The most sure and natural guardians of the whole constitution are the depositary bodies of the powers, then all the citizens. [...] To prevent the confusion or the usurpation of the powers, one must give to them who exercise these powers means that sufficiently resist the attempts directed against them, that they are forced to respect each other by the feeling of their force and their dignity. In the organisation of the government each of these parts have

\footnotetext{
${ }^{373}$ Thibaudeau, Antoine-Claire (1795), Moniteur, 24 Thermidor III, 1239ff.: 'Si l'on examine le résultat de leurs recherches [celles des publicistes qui se sont intéressés à la séparation des pouvoirs], on verra qu'ils ont trouvé deux sortes de moyens de contenir les pouvoirs, les uns qui leur sont extérieurs, les autres qui leur sont inhérents [à l'organisation même des pouvoirs]. Parmi les premiers, on peut classer l'appel au peuple, des censeurs, ou tout autre corps établi pour juger des infractions à la constitution.'.

${ }^{374}$ Thibaudeau, Antoine-Claire (1795), Moniteur, 24 Thermidor III, 1239ff.: 'On sait combien il est dangereux, ou au moins illusoire, de soumettre des questions constitutionnelles à la décision d'une grande nation; ce sont des épreuves qu'on ne tente pas souvent, sans compromettre l'ordre social et la tranquillité publique.'

${ }^{375}$ Thibaudeau, Antoine-Claire (1795), Moniteur, 24 Thermidor III, 1239ff.: 'Voyons maintenant si un corps institué au-dessus des pouvoirs publics, pour examiner leurs actes, comme on propose, est capable de garantir leur indépendance et l'intégrité de la constitution, et je me fais sur-lechamp cette question: Si le jury constitutionnaire, dont les fonctions seront déterminées par la constitution, en passe les limites, qui est-ce qui réprimera son usurpation? Je vous avoue que j'ai beau chercher une réponse, je n'en trouve point de satisfaisante. [...] Ainsi chez un peuple des Indes la croyance vulgaire est, dit-on, que le monde est porté par un éléphant, et cet éléphant par une tortue; mais quand on vient à demander sur quoi repose la tortue, adieu l'érudition.'
} 
to be established and posed in such a manner that they keep all the others at their places; one must oppose the ambition to the ambition. ${ }^{376}$

With the paradox of the elephant and the turtle, Thibaudeau asks anew the old question: who watches the watchers (quis custodiet ipsos custodes?), only to conclude that there could be no reasonable, erudite solution to this intractable problem. $^{377}$

\subsection{Defeat of Sieyès' Jury Proposal and Its Consequences on the French Constitutional Jurisdiction}

Thibaudeau was only one voice in the Convention against Sieyès' project. The lawyer Joseph Eschassériaux, ${ }^{378}$ for example, was better disposed towards the constitutional jury than Thibaudeau, but he too rejected the function of natural equity, declaring it 'useless in our system of civil legislation, and dangerous in politics. ${ }^{379}$ Others, including Louis-Marie de La Révellière-Lépeaux, ${ }^{380}$ Denis

\footnotetext{
${ }^{376 ،}$ Les gardiens les plus sûrs et les plus naturels de toute constitution sont les corps dépositaires des pouvoirs, ensuite tous les citoyens. [...] Pour prévenir la confusion ou l'usurpation des pouvoirs, il faut donner à ceux qui les exercent des moyens tellement suffisants pour résister aux tentatives dirigées contre eux, qu'ils soient forces à se respecter mutuellement par le sentiment de leur force et de leur dignité. II faut que dans l'organisation du gouvernement chacune de ses parties soit établie et posée de manière à retenir toutes les autres dans leur place; il faut, pour ainsi dire, opposer l'ambition à l'ambition.' (Emphasis mine.) This expression paraphrases James Madison's doctrine of the separation of powers. Madison, James, Federalist No. 51, in Hamilton, Madison, and Jay (1961), The Federalist Papers, 322: 'Ambition must be made to counteract ambition.' Even so, while the American constitutional system was the first to introduce the control of the constitutionality of laws, this adoption has remained elusive for the French, up to and including within the current Fifth Republic.

${ }^{377}$ Thibaudeau, Antoine-Claire (1795), Moniteur, 30 Thermidor III, 1330: 'Ainsi chez un peuple des Indes, la croyance vulgaire est, dit-on, que le monde est porté par un éléphant, et cet éléphant par une tortue; mais quand on vient demander sur quoi repose la torture, adieu l'érudition.'

${ }^{378}$ Joseph Eschassériaux (1753-1823/24): Born in 1753 near Saintes, Eschassériaux quickly became involved in politics, entering the parlement of Bordeaux in the 1770s. Elected to the Convention in 1792, he was an active member until 1795. He took up a position in the Tribunat in 1800 (being appointed in 1799), and served until 1804. Thomas (1915), 930.

${ }^{379}$ Eschassériaux, Joseph (1795), Moniteur, 30 Thermidor III, 1329.

${ }^{380}$ Louis-Marie de La Révellière-Lépeaux (1753-1824): Born in the Vendée in 1753, (de) La Révellière-Lépeaux became a lawyer as well as a political activist. A moderate republican, he nevertheless voted for Louis XVI's execution, though he sided with the Girondins when they were purged by the Mountain Jacobins. Because of this, he was also condemned to death, but he was able to escape and evade capture. In 1795, after the fall of Robespierre, he returned to the National Convention, became a member of the Executive Directory, and rose to president of the department for science, morals, and religion. He died in 1824. Thomas (1915), 1492.
} 
Toussaint Lesage, ${ }^{381}$ and Jean-Baptiste Louvet de Couvray, ${ }^{382}$ also intervened in the Convention. According to Louvet de Couvray on 30 Thermidor III (17 August 1795), the control of the constitutionality was already present in the Constitution of the Year III itself, given the obligation 'imposed on the executive power to annul the acts of its subordinates which are unconstitutional and in regard with this obligation it [the executive] is responsible, as it is for the infringements that it could committed itself to the constitutional act., ${ }^{383}$

Though Sieyès' ideas of a constitutional jury were roundly defeated in the discourses of 1795, the concept nevertheless found its way into the Consulate Constitution of the Year VIII (1799) ${ }^{384}$ in the form of the College of Conservators (Collège des conservateurs), later the Conservatory Senate (Sénat). ${ }^{385}$ This constitution replaced the centrality of the legislative power as characteristic for the revolutionary tradition with the primacy of the governmental function, ${ }^{386}$ and therefore made the control of constitutionality more a political than a juridical question. As Paul Bastid has demonstrated, '[considered] under its political aspect, the jury or the college represented a kind of great revolutionary academy, where the traditions of 1789 became seen to be piously conserved and maintained. ${ }^{387}$ This

\footnotetext{
${ }^{381}$ Denis Toussaint Lesage (1758-96): Toussaint Lesage was born in Chartres in 1758, and took up law. He was elected to the Convention in 1792 and served until 1795. A member of the Girondin faction, he was generally progressive in his view that the Revolution should alleviate poverty and, though he voted to find Louis XVI guilty of treason and for him to be condemned to death, he also wanted him pardoned. The rise of the Mountain faction and the purging of the Girondins sent him into hiding, but maintained a strong reputation and, upon his return in 1795, was appointed to the Council of Five Hundred. He died unexpectedly in 1796, during a sitting of the Council. Assemblée Nationale (2017), "Denis Toussaint Lesage".

${ }^{382}$ Jean-Baptiste Louvet de Couvray (1760-97): Born in Paris in 1760, Louvet first made a name for himself as an author with revolutionary tendencies. In 1792 he was elected to the Convention as member of the Girondins; that year, he attacked Maximilien de Robespierre, Jean-Paul Marat, and other important Montagnards, in a prominent speech. This led to his proscription in 1793. He escaped Paris, returning in 1794 but only coming out of hiding after Robespierre's downfall. By 1795 he had been rehabilitated, that he not only returned to the Convention, but became a member of the Council of the Five Hundred. He was to take up a government position in Palermo, but he died in 1797 before accepting the post. Thomas (1915), 1586.

${ }^{383}$ Louvet de Couvray, Jean-Baptiste (1795), Moniteur, 30 Thermidor III, 1328.

${ }^{384}$ For the 1799 Constitution cf. Bourdon (1942); Ponteil (1954); Pertué (1989), 286-7; Timbal and Castaldo (2000), 521-5.

${ }^{385}$ Set up under the Consulate Constitution of the Year VIII following the coup of 18 Brumaire, the Sénat conservateur ('Conservative Senate') met in the Luxembourg Palace since 1799. As core feature in Napoleon's regime, competent for the supervision over the survival of the Constitution, it convened until the Bourbon Restoration of 1814. This first Senate was staffed with only sixty inamovible (immoveable, i.e. permanent) members, at least forty years old; two supplementary members were called upon every year for ten years, amounting to twenty supplementary members. ${ }^{386}$ Pertué (1989), 286: 'Tournant le dos à la tradition révolutionnaire, la constitution de l'an VIII confiait exclusivement la proposition des lois au gouvernement.'

${ }^{387}$ Bastid (1970), 445.
} 
shift away from a legal understanding towards a more political constitutionalism was also indicated by the renaming of Sieyès' jury as a 'college' and 'senate. ${ }^{388}$

The college or senate as the a priori highest organ in the constitutional hierarchy was composed of eighty members, both under the name of the college and the senate; for becoming member it was necessary to be at least forty years old. The choice of members was less free because the senate was obliged to choose among three candidates presented, one by the legislative body (corps législatif), the second by the tribunat, ${ }^{389}$ and the third by the first consul; furthermore, if the same candidate was presented by all three of them, the Senate had to accept him.

Art. 21 of the 1799 Constitution mandated the Senate with the control of constitutionality of laws and governmental acts, ${ }^{390}$ but the control authority was limited in Art. 29 to non-binding recommendations. The Senate's opinions on the unconstitutionality 'do not have a necessary consequence nor obliges any constituted authority to a deliberation' (Art. 29). ${ }^{391}$ This was the negation of the jury and the end of Sieyès' project, in the very moment where it seemed to be realised. The role of the Senate, namely to control the respect of the constitution and to guarantee the constitution's superiority in relation to other norms via a preventive control (Art. 37), ${ }^{392}$ remained theoretical. In practice, the disposition of Art. 21 had no effect: on the one hand, the Senate could not decide all alone and the tribunat was hesitant in entering any conflict with the government; on the other hand, no governmental act was ever revoked by the Senate. One historian has correctly remarked that, ' $[\mathrm{u}] \mathrm{nder}$ the consulate and under the two empires, one established a senate as guardian of the constitution. But this guardian was always a docile instrument between the hands of the first consul and the emperor. ${ }^{393}$

Therefore, the control of constitutionality of laws-theorised by Sieyès in Year III and constitutionalised in Year VIII-as an important and perhaps the most innovative part of the Consulate Constitution, was in practice never a functional element, and its defeat represented the first and the last attempt to create in France a neutral power of a political-jurisdictional nature. ${ }^{394}$ Even today, the refusal of

\footnotetext{
${ }^{388}$ Jaume (2002), 129: 'Bien plus ou bien autrement qu'une Cour constitutionnelle, ce jury est un gardien de la République’.

${ }^{389}$ The Tribunat assumed some of the functions of the Council of Five Hundred, but its role consisted only of deliberating projected laws before their adoption by the Corps législatif, with the legislative initiative remaining with the Council of State.

${ }^{390}$ 'II [le Senat conservateur] maintient ou annule tous les actes, Constitutions qui ont régi la France qui lui sont déférés comme inconstitutionnels par le tribunat ou par le gouvernement.' Constitutions qui ont régi la France, ed. Tripier (1879), 171.

${ }^{391}$ Constitutions qui ont régi la France, ed. Tripier (1879), 173.

${ }^{392}$ 'Tout décret du corps législatif, le dixième jour après son émission, est promulgue par le premier consul, à moins que, dans ce délai, il n'y ait eu recours au Senat pour cause d'inconstitutionnalité. Ce recours n'a point lieu contre les lois promulguées.' Constitutions qui ont régi la France, ed. Tripier (1879), 174.

${ }^{393}$ Ky (1926), 185.

${ }^{394}$ Lacchè (2016), 261-2.
} 
Sieyès' ideas continues to have an effect. The law as expression of the volonté générale, issued by a sovereign legislative assembly, was also the basis of the 1958 Constitution of the Fifth Republic; this introduced the Constitutional Council (Conseil constitutionnel), ${ }^{395}$ but the constitution itself is only very reluctantly exposed to control of constitutionality embodied in the Conseil, as the priority question of constitutionality expressed in Art. 61-1 demonstrates. In Art. 89, the 1958 Constitution expressly forbids constitutional revision, because the people are held to be continuously constituent (le peuple constituant toujours), and there is no control of constitutionality of constitutional amendments. It is, therefore, unsurprising that there is no scholarly consensus as to the precedential role played by Sieyès' draft in relation to modern constitutional courts. ${ }^{396}$

The unanimous refusal of Sieyès' draft in the Convention was introduced by Thibaudeau's statement that 'one must oppose the ambition to the ambition.' In doing so Thibaudeau echoed James Madison's contention that '[a]mbition must be made to counteract ambition. ${ }^{397}$ Though Madison and Thibaudeau seem here to agree on the issue of the separation of powers, the paradox remains that, at the end of the eighteenth century, the American constitutional system was able to introduce a control mechanism for the constitutionality of the laws - the first of its type. France, on the other hand, found itself unable to countenance this control, or to reconcile it with the nature of constitutionalism. Thus, while constitutional control remains a hallmark of the American political system, and has been so since the time of Madison, the modern French Fifth Republic, like the First, still views such controls with suspicion and reluctance.

\section{Avenues of New Constitutional Research: Sketching Germany, 1848-9}

Reconsidering constitutional formation, it is clear that the early period of European constitutionalism was characterised by the establishment of constitutional normativity. This establishment adapted the different ideas of the American and French Revolutions, though this was hardly a straightforward process. As Goethe's Zahme Xenien poetically suggested, the Old World's transition to the new juridification of the political order was always destined to be significantly more complex than that of the (relatively) clean slate of North America. A key example of this complexity was

\footnotetext{
${ }^{395}$ In lieu of many: Avril (2005); especially on the légicentrisme de la culture juridique française and the distrust of judges, Hourquebie (2004).

${ }^{396}$ In contrast to the majority assessment, as provided by Bastid, Gauchet, Clavreul, and Bredin (among others), Michel Troper points out that the constitutional jury proposed by Sieyès is significantly different from the constitutional courts that we know today. Troper, "Sieyès et le jury constitutionnaire", 272; cf. also Fioravanti (1999), 117.

${ }^{397}$ Madison, James, Federalist No. 51, in Hamilton, Madison and Jay (1961), The Federalist Papers, 322.
} 
the struggle for national unification in Germany during the revolutionary years of 1848-9. On the one hand, German theorists and activists did not exist in a historical vacuum, and could draw upon the examples and lessons of both the United States and France. ${ }^{398}$ On the other hand, half a century after the efforts of Hamilton and Madison in the United States, and Sieyès in France, the constitutional debates of St. Paul's Church occurred within the context of a substantive politicisation of the broad population, creating a public discourse of constitutional legal matters in newspapers and pamphlets.

French theorists tended to view fundamental laws as philosophical truths. The German protagonists of imperial constitutionalism, on the other hand, relied on legal techniques against the complicated and irreconcilable backdrop of liberal claims for an unified government backed with popular representation and democratic claims for popular representation, together with the demands of the Prussian and Austrian Ultras, the Hegelian Left and the Junge Deutschland national literary movement, and political Catholicism. ${ }^{399}$ By means of a statute the National Assembly proclaimed the 'Fundamental Rights of the German People' (Grundrechte des deutschen Volkes ) and provided for their immediate application disregarding all the unsolved questions in the constituent St. Paul's Church assembly. The Act Relating to the Fundamental Rights of the German People (Reichsgesetz betreffend die Grundrechte des deutschen Volkes) was proclaimed on 27 December 1848 due to the National Assembly's resolution six days before, months before the Frankfurt Imperial Constitution of 28 March 1849, coming into force on 17 January 1849 before being abrogated by federal decision on 23 August 1851. Prussia, Austria, Bavaria, and Hanover refused the publication of the fundamental rights.

Recent research, conducted under the auspices of the ReConFort project by Franziska Meyer (University of Passau) and Joachim Kummer (Free University of Berlin), has demonstrated that the public interest surrounding the juridification of the German national unification movement extended well into the legal aspects and challenges facing the St. Paul's delegates. ${ }^{400}$ This public engagement with the issue of constitutionalism was facilitated by the publication of numerous newspapers and pamphlets, and broadly addressed three themes: the aforementioned juridification, supremacy, and revision. ${ }^{401}$

\footnotetext{
${ }^{398}$ Cf. fundamentally Dippel (1994), $24 \mathrm{ff}$.

${ }^{399}$ Stolleis (2001), 138.

${ }^{400}$ Franziska Meyer and Joachim Kummer, per "Constitutional Precedence as Keystone of Modern Constitutionalism", Royal Flemish Academy of Science and Art, 14 March 2016.

${ }^{401} \mathrm{http}$ ://sources.reconfort.eu.
} 


\subsection{Juridification Matters in the Public Sphere Around the Constituent St. Paul's Church Assembly}

The differentiation between constitution and ordinary law was addressed in the German Constitutional Newspaper (Deutsche constitutionelle Zeitung) as basic legal framework and detailed singular provisions. In an article comparing the constitutions of Belgium and the United States to the constitution of Bavaria, an author for the paper distinguished 'a well drafted constitution [which] should only regulate fundamental principles and not every detailed legal question' from the ordinary law. ${ }^{402}$ The People's Friend (Volksfreund) claimed the constituent power for the people instead for the monarch 'because it is the most important law. ${ }^{403}$ Conversely, the National-Newspaper (National-Zeitung) built the new order on the unification more than on the constitution: 'The constitution is necessary, but the statal unification gives a new quality of legal bonding to the powers. ${ }^{404}$ In the same vein, the criticism of the written crystallization of the constitution in a single document used the unwritten British constitutional framework as its exemplar, arguing that its foundation 'on a solid political custom is far stronger than any written text'. 405

\footnotetext{
402“'Zur Verfassungsfrage Deutschlands”, Deutsche constitutionelle Zeitung, No. 294, 4 November 1848. This idea of a regulation only of 'fundamental principles' was established in the final form of the Reichsverfassung (1849). Many detailed questions were left open, including those regarding the suspension of fundamental rights (Art. 197 Section 2) as well as constitutional complaint (Art. 126g). The Deutsche constitutionelle Zeitung, a centre-left newspaper, was published from 1 January 1848 until 7 October 1849 in Augsburg and Munich.

${ }^{403}$ “Die von der Regierung 'von Gottes Gnaden' dem Volke angebotene Verfassung”, Der Volksfreund, No. 27, 23 December 1848: 'Eine solche Verfassung ist das wichtigste Gesetz des Staates, sie ist das Staatsgrundgesetz, und da in einem constitutionellen Staate das Volk die gesetzgebende Gewalt hat, so kann natürlich nur das Volk durch seine Vertreter das wichtigste alle Gesetze geben, nie die Regierung von Gottes Gnaden.' Der Volksfreund, which was published in Bielefeld by Rudolf Rempel and Gustav Adolf Wolff, was issued from 10 June 1848 until 12 July 1850 . The newspaper championed republican and pro-revolutionary ideas. See, for instance, "Die Republik in Vergleichung mit den monarchistischen Verfassungsformen", Der Volksfreund, No. 5, 3 February 1849; "Revolution", Der Volksfreund, No. 10, 10 March 1849.

404"'Die Deutsche Verfassung", National-Zeitung, supplement to No. 36, 8 May 1850: 'Die Gerechtigkeit, welche bisher für die einzelnen Staaten immer nur eine kraftlose Idee blieb, wird so $z u$ einer concreten Macht (wir wollen so die Reichsgewalt im Gegensatz zur einzelnen Staatsgewalt nennen), und die den Völkern bisher nur durch die Verfassungs-Urkunde gebotene papierne Bürgschaft für die Gerechtigkeit wird eine reelle.' The National-Zeitung was founded in 1848 , as a consequence of the revolutionary events. The first proprietors and correspondents were generally cosmopolitan Berlin liberals - politicians, intellectuals, authors, and state officials. The newspaper published its political program in its first edition, in which it favoured a constitutional monarchy based upon democratic principles and institutions. By 1850, the National-Zeitung had some of the highest circulation figures in Berlin. With the failure of the revolutions, the paper became more moderate, and continued to enjoy a signifiant readership, until it was wound down in 1938. Kahl (1972), 177-80.

405“Ueber constitutionelle Garantien und Ministerverantwortlichkeit", Deutsche allgemeine Zeitung, No. 338, 3 December 1848: 'Nach den Erfahrungen, welche mit den s.g. papieren
} 
The juridification by constitution was further reflected by reporting on the oath to be taken by the king, the ministers, parliamentarians, and the military on the constitution. ${ }^{406}$ The communicative message of the obligatory oath taken on the constitution before entering into office was twofold. On the one hand, it raised the prospect that all political power could only exist as constituted power. On the other hand, it was a solemn promise to respect the constitution. The latter was noted as being fragile, ${ }^{407}$ owing to the lack of a legal consequence in its enforcement. ${ }^{408}$ Consequences for the breach of oath were left to the regulation by the practical custom. Referring to the oath of Charles X of France, the constitutional oath of the king, in particular, was considered to be easily compromised. ${ }^{409}$

Of primary importance was the potential conflict between the oath sworn on the constitution by the military and the obligations to the supreme command of a

Verfassungen, d.h. mit Constitutionen und Charten, welche das ganz organische Gesetz eines Reiches umfassen, bisher gemacht worden sind, überrascht es einigermaßen, daß die Völker noch immer geneigt sind, darin die Gewähr für Freiheiten und volkstümliche Regierung [...] erblicken. [...] Sieht man in Europa sich nach Ländern um, wo die verfassungsmäßige Freiheit die tiefsten Wurzeln geschlagen hat, so bleibt nur der Blick auf Großbritannien haften; doch nehmen die Schweiz in einem verwandten Sinn und das verjüngte Belgien [...] daneben eine sehr achtbare Stelle ein.' The Deutsche allgemeine Zeitung was published in Leipzig by Heinrich Brockhaus from 1 April 1843 until 31 December 1879. Politically it belonged to the liberal spectrum. Berbig (2000), 29. The incapability of the written constitution was also emphasized by the work of a contemporary, anonymous Bavarian author: Die Grundrechte und die Reichsverfassung für Deutschland, beleuchtet von einem Bayer (Augsburg: 1849), 74: 'Mit einer papiernen Verfassung hat man kein Reich. Papieren aber ist jede Verfassung, die nicht auf das Recht gebaut ist; denn Gesetze sind als solche aber noch nicht Recht. Das Recht fordert bei jeder Societät, daß die Interessen des einen Theilnehmers nicht durch das Uebergewicht des Anderen bewältigt werden können; nur in diesem Falle wird ein gemeinschaftliches Interesse verfolgt werden können.'

${ }^{406}$ For members of parliament: Art. 113; for ministers: Art. 191; for the head of state: Art.190. Frankfurter Reichsverfassung (28 March 1849), cited according to Willoweit and Seif (=Müßig) (2003), 562-88.

407،"Zur Verfassungsfrage Deutschlands XI", Deutsche constitutionelle Zeitung, No. 45, 22 February 1849: 'Man hätte [...] noch einen kleinen Zusatz erwarten sollen, etwa den, daß alle mit der Reichsverfassung in Widerspruch stehende Gesetze [...] an und für sich aufgehoben und ungültig seien, sobald die Reichsverfassung in Kraft trete.' See also: "Die Gewähr der Reichsverfassung", Deutsche Reichstags-Zeitung, No. 28, 2 February 1849. The Deutsche Reichstags-Zeitung was published from 21 May 1848 until 2 April 1849 in Bonn by Robert Blum, Georg Günther, and Wilhelm Schaffrath. Politically it belonged to the left. It frequently issued and supported the pamphlets of the democratic Centralmärzverein (Central March Association), and was sceptical towards the Frankfurt Assembly's practice. See, for example, "Des deutschen Volkes Mandat an seine Vertreter I", Deutsche Reichstags-Zeitung, No. 133, 22 October 1848; "Stimmen aus dem Lande gegen die Erschaffung eines deutschen Kaisers", Deutsche Reichstags-Zeitung, No. 12, 15 January 1849 .

${ }^{408}$ Schmidt (2000), 150.

${ }^{409}$ This article also draws a comparison to the oath of Charles X of France (1757-1836), who pursued 'unconstitutional politics.' "Zur Verfassungsfrage Deutschlands XI", Deutsche constitutionelle Zeitung, No. 45, 22 February 1849. 
federal state. ${ }^{410}$ This originated in the simple fact that, though the St. Paul's debates concerned the German 'nation', the practical institutions of governance remained the purview of the federal states. This meant that the German armies were answerable not to the nation - as, indeed, there was no national German army - but to their individual states, such as Prussia, Hanover, Bavaria, and Württemberg. Therefore, if the military sworn to uphold a particular command and to serve a particular state had to pledge loyalty to the national constitution, it would be caught between two camps. If a federal state were to raise its military forces against the imperial constitution, to which oath would the military pledge its loyalty: the nation and its constitution, or the federal state $?^{411}$ In the same vein, the Prussian politician and minister of finance, David Justus Ludwig Hansemann, argued 'that the oath of the military [on the Constitution] would be a threat to its discipline. ${ }^{412}$ Whether this intractable problem could, in fact, be resolved ultimately became a moot point; as the Imperial Constitution was never enacted, the fundamental test of the loyalty and discipline of the armies never came to pass. Nonetheless, as Hansemann had alluded, at the heart of the military issue was a basic and vital question of precedence, and what the Imperial Constitution (or, indeed, any constitution) represented in terms of vested power.

\footnotetext{
${ }^{410}$ The solution envisaged in Art. 11 of the Frankfurt Reichsverfassung, which eliminated the supreme command of the federal states, did not come into force. $\S 11$ stated: 'Der Reichsgewalt steht die gesammte bewaffnete Macht Deutschlands zur Verfügung.'.

411“23. Oktober", Deutsche Reform, No. 8, 24 October 1848: 'Bei einer solch doppelseitigen Verpflichtung wird nämlich die Armee aus einem gehorchenden in einen beurtheilenden Körper verwandelt; denn selbst urtheilen und sich mit der Politik befassen, wird jede deutsche Armee müssen, wenn sie bei Konflikten zwischen der Reichsgewalt und den Einzelregierungen ihre Pflicht erkennen will.' The Berlin newspaper Deutsche Reform was founded in 1848. A conservative newspaper, it had the aim of protecting the constitutional monarchy against liberal democracy and anarchy. The government supported the newspaper monetarily, while the paper published articles written by the government. In spite of this (or perhaps because of it), the readership was very small. In 1849, the newspaper was reformed and removed from the government strategy, but still did not succeed; it folded in 1851. Berbig (2000), 40-1.

${ }^{412}$ Hansemann, David (1849), Die Deutsche Verfassung, 8. David Hansemann was an important German merchant. Born in 1790 as the youngest son of a pastor in Finkenwerder, he entered commerce at just fifteen years old. In 1817 he founded his own company and succeeded to gain certain prosperity. This way he was able to spend the following time on his interests in insurance and social politics, railways, and banking. He founded an insurance company, a credit institute, and a railway company. He held several public offices, including the presidency of the local chamber of commerce and the city council. Hansemann was known for his liberal ideas, which often stood in conflict with the public offices In March 1848, following the outbreak of revolution across the region, he became the Prussian finance minister. He held this position only until September, when the rising tide of radical democrats led to his resignation. Hansemann himself was a German unificationist who supported a federalised 'Greater German' (großdeutsch) solution - the unification of the German states, including Austria, with a strong devolution of powers to the individual states. At the beginning of the $1850 \mathrm{~s}$, he withdrew from politics and founded a credit cooperative. He died in 1864 in Schlangenbad. "Hansemann, David", Neue Deutsche Biographie (1966), 7: 626-9.
} 


\subsection{Supremacy Matters in the Public Sphere Around the Constituent St. Paul's Church Assembly}

The introductory statute to the Act Relating to the Fundamental Rights of the German People (hereafter Fundamental Rights Act; 1848) ${ }^{413}$ ruled that every federal law contradicting the fundamental law act was either immediately null and void, or else must be amended within a certain period of time. The fundamental laws were communicated as obligatory legal standards to be complied with by the federative governments while also setting the legal requirements to change singular legal structures accordingly. ${ }^{414}$ Most prominently, Art. 2 of the Fundamental Rights Act attracted journalistic attention by abolishing the estates' privileges. Liberal newspapers, such as the Deutsche constitutionelle Zeitung, even demanded the closing of the first chamber of Bavaria, which acted as a legislative body of hereditary privilege similar to the British House of Lords. ${ }^{415}$ As an expression of noble entitlement, the first chamber could no longer be tolerated under Art. 2 of the Fundamental Rights Act.

What was particularly remarkable was the liberal linguistic turn away from seeing the Fundamental Rights Act as a protective right, and instead conceptualising it as an active measure to be wielded to change the structure and law of the federal states. This, however, did not occur without opposition, and conservative protest was widespread. The New Munich Journal (Neue Münchener Zeitung), for instance, argued that fundamental laws were not immediately effective; instead, they had to be approved by the federative government and parliament respectively. For conservatives, such an implementing approval was the only constitutional way to introduce the fundamental laws into a federal state. ${ }^{416}$ This amounted to a constitutional understanding not as a paramount law but rather as a mere societal contract.

The nullification of anterior law started as a matter of course. The National Assembly already agreed in May 1848 that a law contradicting the constitution was

\footnotetext{
${ }^{413}$ The Reichsgesetz betreffend die Grundrechte des deutschen Volkes, proclaimed on 27 December 1848, came into force on 17 January 1849.

${ }^{414}$ This is made clear by the introductory act to the fundamental law. In Arts. 3, 4, and 5 the federal governments are told to amend themselves according to the fundamental laws.

${ }^{415}$ "Die deutschen Grundrechte und die bayrische Volksvertretung", Deutsche constitutionelle Zeitung, No. 38, 14 February 1849: 'Das Einführungsgesetz zu den deutschen Grundrechten verordnet deshalb die Abänderung eines derartigen Zweikammernsystems, und setzt hierfür eine Frist von 6 Monaten fest [...] Also zuerst hinweg mit dieser s.g. ersten Kammer!'.

416،'Die Grundrechte”, Neue Münchener Zeitung, No. 99, 27 April 1849: 'Keineswegs soll hiermit übrigens die Einführung der Grundrechte in Bayern bekämpft werden; diese soll und wird geschehen auf verfassungsmäßigem Wege unter Mitwirkung und Zustimmung des Landtages und der Regierung und so, wie von diesen für das Land möglich, zuträglich anerkannt wird.' The Neue Münchener Zeitung existed from 1848 until 1855 (anew: 1856-1862). The newspaper was founded on suggestion of King Maximilian II; as a result, it relied on the Bavarian government for both its financial support and its content. Kohnen (1995), 154.
} 
null and void. ${ }^{417}$ Art. 30 of the draft constitution went so far as to state explicitly that '[e]very resolution, federal law or treaty between federal states, are void, insofar as they contradict the National Constitution. ${ }^{418}$ The Frankfurt Imperial Constitution (Reichsverfassung; 1849), however, lacked legal consequences for laws contradicting the constitution. The relevant Art. 194 simply stated 'that the ordinary law must not contradict the national constitution. ${ }^{419}$ Despite the hierarchisation of constitution and statutes, an explicit nullification of contradictory statutes was missing. Centre-left newspapers criticised this oversight, and justified their demand of the nullification with comparative arguments, though these often included inaccuracies and mischaracterisations. ${ }^{420}$ So, for example, the Free People's Gazette (Freie Volksblätter) reported that the Belgian Constitution (1831) allowed state officials to refuse the execution of laws they thought to be issued unconstitutionally. ${ }^{421}$ In fact, the relevant provision-Art. 107-only referred to judges, and no other officials.

The public interest in the establishment of a constitutional jurisdiction and the introduction of a judicial review corresponded with the prominence of judicial administration and legally established courts within liberal legal thought. Deeply influenced by Immanuel Kant's formulation of the liberal state under the rule of law, Paul Johann Anselm von Feuerbach's essay on the Bavarian court

417“Die deutsche Einheit", National-Zeitung, No. 63, 5 June 1848: 'Die deutsche Nationalversammlung hat am 27. Mai mit einer entschiedenen Mehrheit nach Wernhers Antrag beschlossen: die deutsche National-Versammlung, als das aus dem Willen und den Wahlen der deutschen Nation hervorgegangene Organ zur Begründung der Einheit und der politischen Freiheit Deutschlands, erklärt, daß alle Bestimmungen einzelner deutscher Verfassungen, welche mit dem von ihr zu gründen den allgemeinen Verfassungswerke nicht übereinstimmen, nur nach Maßgabe des letzteren als gültig zu betrachten sind - ihrer bis dahin bestandenen Wirksamkeit unbeschadet.'.

${ }^{418}$ Entwurf des deutschen Reichsgrundgesetzes, der Hohen deutschen Bundesversammlung als Gutachten der siebzehn Männer des öffentlichen Vertrauens überreicht am 26. April 1848, Frankfurt am Main, 1848, Art. 30, 22: 'Alle Bundesbeschlüsse, Landesgesetze, und Verträge zwischen einzelnen deutschen Staaten sind, insoweit sie mit einer Bestimmung des Reichsgrundgesetzes im Widerspruch stehen, hiermit außer Kraft gesetzt.'

${ }^{419}$ Verfassung des Deutschen Reiches vom 28. März 1849, Art. 194: 'Keine Bestimmung in der Verfassung oder in den Gesetzen eines Einzelstaates darf mit der Reichsverfassung in Widerspruch stehen.' Cited in Willoweit and Seif, Europäische Verfassungsgeschichte, 587.

${ }^{420}$ "Zur Verfassungsfrage Deutschlands XI", Deutsche constitutionelle Zeitung, No. 45, 22 February 1849: 'Man hätte [...] noch einen kleinen Zusatz erwarten sollen, etwa den, daß alle mit der Reichsverfassung in Widerspruch stehende Gesetze [...] an und für sich aufgehoben und ungültig seien, sobald die Reichsverfassung in Kraft trete.'

421"'Das konstitutionelle System in Deutschland”, Freie Volksblätter, No. 77, 13 October 1848: 'Er beruft sich auf Belgien, wo nach der Verfassung jeder Beamte befugt ist, ein Gesetz unvollzogen zu lassen, dass ihm verfassungswidrig verordnet scheint.' The Freie Volksblätter (from April until October 1848) or Freie Blätter (from October 1848 until January 1849) was a democratic newspaper printed in Cologne and Mülheim. Melis (1998), 301. 
constitution $^{422}$ and its unaffectedness by means of ministerial and cabinet regulations defined the court constitution as the 'exterior appearance' of justice and the essence of the liberal rule of law state. ${ }^{423}$ In Feuerbach's words, the court constitutional legal reservation correlated to the legal commitment of the adjudicating power: 'If this court constitution does not by itself exist as a law but as a simple regulation, then the judiciary in its most interior circle is made dependent on a non-statute as the highest fundamental rule. ${ }^{424}$ Any regulatory competence of the executive in regard to the court constitution would nip judiciary independence in the bud, as then the legal validity of judicial actions would not alone be measured by laws but also by executive orders. ${ }^{425}$ As opposed to the Rousseau-inspired super-elevation of the general will and the French distrust against judges, German liberal writers, such as Klüber, Mittermaier, Pfeiffer, and Zachariae, were interested in the court constitutional legal reservation as prerequisite of judicial independence $^{426}$ and of the justiciability of subjective rights. ${ }^{427}$

The plea for the introduction of the constitutional complaint was an obvious step. For the activists, the next obvious step was to publish this plea in newspapers and pamphlets. The Württemberg political scientist Robert von Mohl, a member of the Frankfurt Parliament, argued in the German Newspaper (Deutsche Zeitung) that the fundamental rights of each citizen should be secured by an independent and

\footnotetext{
${ }^{422}$ Paul Johann Anselm von Feuerbach, Kann die Gerichtsverfassung eines constitutionellen Staates durch bloße Verordnungen rechtsgültig geändert werden? in Feuerbach, Paul Johann Anselm von (1833), Kleine Schriften vermischten Inhalts, 178-228.

${ }^{423}$ Feuerbach (1833), Gerichtsverfassung, 185 (for the 'exterior appearance'), 193 (for the 'foundation of the legal status in the state').

${ }^{424}$ Feuerbach (1833), Gerichtsverfassung, 199.

${ }^{425}$ Feuerbach (1833), Gerichtsverfassung, 198-200.
}

${ }^{426}$ Klüber, Joahnn Ludwig (1840) Öffentliches Recht des Teutschen Bundes, chap. X (Justizhoheit), § 366, 562-3; § 373, 571-2. Klüber previously discussed judicial independence in the third edition of Öffentliches Recht (Erlangen: 1831) at chap. X (Justizhoheit) $\S 373,521-2$. For the court constitutional legal reservation, Klüber cites Feuerbach: Klüber, Öffentliches Recht (1840), chap. X § 366, 565 (n. k); Öffentliches Recht (1831), chap. X $\S 366$, 515 (n. k). Cf. also Pfeiffer, Burkhard Wilhelm (1831), Practische Ausführungen aus allen Theilen der Rechtswissenschaft, vol. III, 274-5: 'As in general the independence of the administration already requires permanent courts being appointed with an independent authority who may only be deprived of the once assigned legal matters in general and by statute... Since Cabinet justice appears especially reprehensible, then with respect to the safety of the administration of justice, the state legal claim is: that nobody is deprived of his ordinary judge [...] It is precisely this fundamental principle that excludes all kinds of special courts and commissions.'

${ }^{427}$ Klüber elaborates on this reservation in a separate point (VIII) at Klüber (1840), chap. X $\S 366$, 562. His definition of the court constitution (Klüber (1840), chap. X $\S 366,564)$ is based on the one provided by Feuerbach: 'The court constitution (Court Organisation) is the certain order of the courts with the goal to influence their composition, the extent of their effect, and their relationship amongst each other. Its destiny is precisely to give power to the judiciary in its organ, as one of the first and fundamental parts of every state order, in order to assure the effect of the idea and the rule of the law in its entirety in the territory'. 
permanent constitutional court. ${ }^{428}$ Its competences should among others include a constitutional complaint. ${ }^{429}$ This frequent liberal demand was combatted by the state governments, ${ }^{430}$ also using the newspapers as medium. They proposed that a query should first be raised in a federal parliament by a sitting member; only if this failed would the representatives be entitled to appeal to the constitutional court. ${ }^{431}$ In this version, power would be vested in the political process through the representatives in the parliament; no ordinary citizen would ever be allowed to appeal to the constitutional court personally. Ultimately, though, this obstructive position was not successful. Instead, the St. Paul's delegates wrote $\S 126 \mathrm{~g}$ and $\S 126 \mathrm{~h}$ into the Imperial Constitution. These sections provided for the constitutional complaint of citizens to the planned 'Constitutional Court. ${ }^{432} \S 126 \mathrm{~g}$ determined that 'law suits of German citizens against the infringement of their rights guaranteed by the constitution' had to be ruled by the Imperial Court (Reichsgericht). ${ }^{433}$ The most important textual template was the provision in Title VII, $\S 21$ of the Bavarian Constitution of 1818 , which granted citizens the right to appeal 'to the assembly of estates against the infringement of constitutional rights. ${ }^{434}$ However, this did not allow for a constitutional complaint, rather for a petition in regard to a lawful administration. $^{435}$

\footnotetext{
${ }^{428}$ Cf. fundamentally Dippel (1994), 24ff. In regard to Robert von Mohl further references at Stolleis (2001), 172ff.

429،"Der Deutsche Reichstag III”, Deutsche Zeitung, No. 88, 28 March 1848: 'Dann aber zweitens nicht minder nöthig, daß das Reich eine gesetzliche, wirksame Hilfe gegen die Beeinträchtigungen dieser Rechte, im einzelnen Staate gewähre; somit in unabhängiges, zahlreiches, beständiges Bundesgericht, bei welchem Ständeversammlungen die Minister anklagen, die einzelnen Bürger, welche auch in letzter Instanz im engern Vaterlande Unrecht in staatsrechtlichen Befugnissen zu erdulden glauben, Gerechtigkeit verlangen können.' The Deutsche Zeitung was published from 1 July 1847 until 30 December 1850 by Georg Gottfried Gervinus. Its political position was moderate liberal. It dismissed any radical revolutionary ideas and mostly advocated the hereditary monarchy. See for example "Die Deutschen Reformen", Deutsche Zeitung, No. 82, 22 March 1848; "Die Empörung im Seekreis", Deutsche Zeitung, No. 108, 18 April 1848; "Republikanischer Jesuitismus", Deutsche Zeitung, No. 117, 27 April 1848. See also "Die Bundesverfassung", Deutsche Zeitung, No. 89, 29 March 1848; "Der Entwurf der Reichsverfassung III", Deutsche Zeitung, No. 309, 21 November 1848.

${ }^{430}$ Deutsche Reform, supplement to No. 172, 5 March 1849.

${ }^{431}$ Deutsche Reform, supplement to No. 172, 5 March 1849.

${ }^{432}$ The exact competences of the planned constitutional court were intended to be regulated by ordinary law.

${ }^{433}$ Cf. among others Faller (1974), 827-55.

${ }^{434}$ Bavarian Constitution 1818, Title VII, §21: 'Jeder einzelne Staatsbürger, so wie jede Gemeinde kann Beschwerden über Verletzung der constitutionellen Rechte an die Stände-Versammlung, und zwar an jede der beyden Kammern bringen, welche sie durch den hierüber bestehenden Ausschu $\beta$ prüft, und findet dieser sie dazu geeignet, in Berathung nimmt. Erkennt die Kammer durch Stimmenmehrheit die Beschwerde für gegründet, so theilt sie ihren diesfalls an den König zu erstattenden Antrag der andern Kammer mit, welcher, wenn diese demselben beystimmt, in einer gemeinsamen Vorstellung dem Könige übergeben wird.' Seydel (1885), 30-56. See also Stourzh (2011), 157-79, especially 168-70.

${ }^{435}$ Ruppert and Schorkopf (2015), 1411 with further references.
} 
Even if the reasons for Sieyès' caution with the choice of the constitutional jurors were not applicable to the Frankfurt constitutional debates, there was a particular public interest in the question of how constitutional judges would be elected. Mohl proposed a court with judges and a jury, both of them consisting of members of the parliament. He wanted the judges to be elected by the parliament. The jury of the court should not be elected but rather chosen by lots. For him it was self-explanatory that the king should have no say in the election of the judges and the jury. ${ }^{436}$ Adolph Bach, an otherwise unknown author, preferred the judges to be elected by other judges of lower courts. ${ }^{437}$ He also argued that no one should be able to control them. ${ }^{438}$ A third voice, a professor of philosophy by the name of Braniß, voted for the judges to be elected by the courts and faculties of law. ${ }^{439}$ Despite this vivid discussion around the constituent assembly, the goals of the debates inside its chamber were rather meagre in this respect. In the final analysis, $\S$ 128 of the Imperial Constitution held the organisation of the courts to be a matter of ordinary and not constitutional law. ${ }^{440}$

The failure of the Imperial Constitution specifically, and the Frankfurt Assembly as a whole, often distracts from developments further south. But Frankfurt was not the only centre of debate, negotiation, and compromise during this period of European upheaval. In Austria, the so-called 'Kremsierer Constitutional draft' (1848-9) held the provision that the highest imperial court should be the only competent instance for 'lawsuits for compensation due to the infringement of constitutional rights by an official act of state employees. ${ }^{, 41}$ This draft was not present in the analysed public discourse around the St. Paul's Assembly, and it was

\footnotetext{
436“Der Deutsche Reichstag IV”, Deutsche Zeitung, No. 89, 29 March 1848: 'Das eine Ausnahme, von dem Grundsatze, der Kaiser habe die sämtlichen Reichsbeamten zu ernennen, hinsichtlich der Mitglieder des Reichstages zu machen ist, bedarf, wohl keiner Ausführung.'

${ }^{437}$ Bach, Adolph (n.d.), Umriß einer Staatsverfassung für Deutschland, 221: 'Es möge [...] die Einladung ergehen, zum Behufe der Bildung des höchsten Reichsgerichts, einen Collegen aus der Mitte [...] ohne alle äußere Einwirkung zu wählen.'

${ }^{438}$ Bach, Adolph (n.d.), Umriß einer Staatsverfassung für Deutschland, 9: 'Deutschlands höchstem Gerichtshofe [...] kommt ausschließlich die oberste Aufsticht und Controlle über sämtliche Gerichte des Reiches zu und darf selbst nicht unter der Bevormundung und Instructions-Befolgung eines Staatsmannes stehen.'

${ }^{439}$ Braniß, Christian Julius (1848), Nationalverfassung und preußische Constitution, 32: 'Den Wahlact vollziehen in den einzelnen Staaten nicht die Kammern, sondern die Obergerichte und die Justizfakultäten.' Christian Julius Braniß was a German philosopher, born in 1792 . He worked as a professor in Breslau, and was influenced by Steffens and Hegel. Drawing from these, he created his own philosophical system, differentiating between the philosophy of idealism or metaphysics and 'real' philosophy. He died in 1873 in Breslau. "Braniß, Christian Julius", Allgemeine Deutsche Biographie (1903) 47: 184.

${ }^{440}$ Verfassung des Deutschen Reiches (28 March 1849), § 128: 'Über die Einsetzung und Organisation des Reichsgerichts, über das Verfahren und die Vollziehung der reichsgerichtlichen Entscheidungen und Verfügungen wird ein besonderes Gesetz ergehen.' Cited in Willoweit and Seif (=Müßig) (2003), 579.

${ }^{441}$ Die österreichischen Verfassungsgesetze mit Erläuterungen, ed. Bernatzik (1911), 129 ` 140. Das Oberste Reichsgericht hat als einzige Instanz das Richteramt auszuüben: 1. bei Klagen auf
} 
not before the Austro-Hungarian Compromise of 1867 that an individual constitutional complaint was introduced in Austria. Regarding the establishment of an imperial court, the Austrian Fundamental Law attributed to this court the competence for 'complaints of citizens on the infringement of their political rights guaranteed by the constitution' (after the exhaustion of all legal measures provided by the administrative law). ${ }^{442}$ However, the verdicts of this imperial court had no annulling effect, but instead were only declarative. The detailed drafting of the Austrian imperial court (excluding the Hungarian territories of the Austro-Hungarian Empire) was left to the implementing law of 18 April 1869, ${ }^{443}$ which coincided with the court coming into life. $\S 17$ of the implementing law regulated the proceedings of the individual constitutional complaint and made the legal nature of the genuine complaint explicit in $\S 35$, providing for the wording of the ruling that citizens' rights were infringed. ${ }^{444}$

\subsection{Revision Matters in the Public Sphere Around the Constituent St. Paul's Church Assembly}

In regard to constitutional amendments, the St. Paul's Constitution imposed the right to amendment proposals to the king and to both houses of the parliament. ${ }^{445}$ Newspapers or pamphlets did not discuss this topic, as the right to initiate for both powers had been generally accepted. The constitutional draft presented on 26 April 1848 by the committee of seventeen under Friedrich Christoph Dahlmann also included the same regulation. ${ }^{446}$ Rather, the procedure, or the means by which amendments would be enacted, attracted more interest. For some newspapers, like the Deutsche constitutionelle Zeitung, juridification by constitution was an

Genugtuung wegen Verletzung konstitutioneller Rechte durch Amtshandlungen der Staatsbediensteten $(\$ 138)$.'

${ }^{442}$ Art. 3b, Staatsgrundgesetz über die Einsetzung eines Reichsgerichtes 21 December 1867, in Die österreichischen Verfassungsgesetze mit Erläuterungen, Vol. II, 428: 'Artikel 3. Dem Reichsgerichte steht ferners die endgültige Entscheidung zu: [...] b) über Beschwerden der Staatsbürger wegen Verletzung der ihnen durch die Verfassung gewährten politischen Rechte, nachdem die Angelegenheit im gesetzlich vorgeschriebenen administrativen Wege ausgetragen worden ist.'

443“Gesetz von 18. April 1869”, Reichsgesetzblatt für das Kaiserthum Österreich, No. XXII, 1869, 167.

${ }^{444}$ In this respect, Austria is considered to have had a pioneering role in continental Europe. Hereto at length: Stourzh (1985, passim).

${ }^{445}$ Verfassung des deutschen Reiches (28 March 1849), § 80: 'Der Kaiser hat das Recht des Gesetzvorschlages. [...]/\$ 99. Das Recht des Gesetzvorschlages, der Beschwerde, der Adresse und der Erhebung von Thatsachen, so wie der Anklage der Minister, steht jedem Hause zu.' Cited in Willoweit and Seif (=Müßig) (2003), 571.

${ }^{446}$ Entwurf des deutschen Reichgrundgesetzes (26 April 1848), § 8, 12-13: 'Dem Kaiser [...]. Das Recht des Vorschlags und der Zustimmung zu den Gesetzen, theilt er mit dem Reichstage.' 
irreversible truth once a constitution had come into force. This was similar to Sieyès' concept of constitutionalism; the transformation from pouvoir constituant to pouvoir constitué was understood as one-way track and, providing that it was passed in a constitutional way, could not be overturned without risking a revolution. $^{447}$ The same could be heard from Heinrich von Gagern, president of the National Assembly, when he called in April 1849 for an adherence to the Constitution "not because the constitution would be perfect or he would be totally convinced by all of the provisions, but the constitution itself determines the procedure for modifications which has to be observed. ${ }^{448}$ Such a statement is embedded in the legal understanding of constitutional precedence; the ratified constitution stood above all, and even a complete modification could only be done in the way the constitution describes. It had to be observed, even if it did not fulfil all of its expectations.

In regard to the modifying quora and majorities, the St. Paul's Constitution determined in Art. 196 that two-thirds of the members had to be present at the voting and a majority of two thirds has to be achieved. These requirements had to be complied with in both chambers. ${ }^{449}$ Many pamphlets advocated for a two-third majority as well, ${ }^{450}$ whereas the constitutional draft of the seventeen demanded a quorum of three-quarters to modify the constitution. ${ }^{451}$ The two-thirds quorum and

447،"Die Einführung der Grundrechte”, Deutsche constitutionelle Zeitung, No. 9, 11 Januar 1849: 'Viel schwerer wird man dasjenige antasten, was auf verfassungsmäßigem Wege festgestellt und zum Gesetz erhoben ist und wird es nicht versuchen, ohne die Revolution aufs Neue und in ihren letzten Konsequenzen hervorzurufen. Darum betrachten wir es als eine Thatsache von hohem Werthe, daß die Vertreter des deutschen Volkes die wichtigsten durch die Märzerhebung gewonnen Grundrechte desselben durch eine in Gesetzform erlassene magna charta verbrieft [...] haben.'

448“"Frankfurt a.M. 11. April”, Deutsche Reform, No. 236, 13. April 1849: 'Gagern: Etwa 80 Mitglieder von der Rechten und dem Centrum der National-Versammlung, unter ihnen auch Mohl und ich, haben schriftlich erklärt, fest an der Verfassung zu halten, nicht, weil alle Punkte mit unserer Überzeugung übereinstimmten, sondern, weil jeder einzelne hier Opfer bringen musste, um in der National-Versammlung etwas zu schaffen. Von der Verfassung darf nichts geändert werden, als auf dem Wege, den die Verfassung selbst vorzeigt.'

${ }^{449}$ Verfassung des deutschen Reiches (28 March 1849), § 196: 'Abänderungen in der Reichsverfassung können nur durch einen Beschluss beider Häuser und mit Zustimmung des Reichsoberhauptes erfolgen. Zu einem solchen Beschluss bedarf es in jedem der beiden Häuser: 1 . Die Anwesenheit von mindestens zwei Dritteln der Mitglieder; 2. Zweier Bestimmungen, zwischen welchen ein Zeitraum von wenigstens acht Tagen liegen muss; 3. Einer Stimmmehrheit von wenigstens zwei Dritteln der anwesenden Mitglieder bei jeder der beiden Abstimmungen. Der Zustimmung des Reichsoberhauptes bedarf es nicht, wenn in drei sich unmittelbar folgenden ordentlichen Sitzungsperioden derselbe Reichstagsbeschluss unverändert gefasst werden.' Cited in Willoweit and Seif (=Müßig) (2003), 587-8.

${ }^{450}$ Achanier (n.d.), Entwurf zu einer deutschen Verfassung, § 10, 7: 'Es kann an der Verfassung nur dann eine Abänderung gemacht werden, wenn solche von der Bundeskammer und dem Senat mit einer Majorität von 2/3 der Stimmen [beschlossen wird].'

${ }^{451}$ Entwurf des deutschen Reichgrundgesetzes (26 April 1848), § 29, 21-2: 'Zu Abänderungen des Reichsgrundgesetzes ist die Übereinstimmung des Reichstags mit dem Reichsoberhaupte, in jedem Hause die Anwesenheit von wenigstens Dreiviertel der Mitglieder und eine Stimmenmehrheit von Dreiviertel erforderlich.' 
majority earned some critics. The Deutsche constitutionelle Zeitung viewed quorum provisions as too complicated at best, and constitutionally dangerous at worst; in the case of minority parties that could not hope to achieve quorum, the paper argued, disillusionment with the process could lead to these parties pursuing extrajudicial means to enact constitutional amendment, including rioting and revolution. $^{452}$

Another branch of criticism was followed by David Hansemann, the Prussian minister of finance, who played a pivotal role in Prussian politics during the revolutionary years of 1848-9. In response to the proposal that the Prussian king should accept the united German crown and modify the constitution afterwards, Hansemann declared that this would set a dangerous precedent, because the constitution could be modified later in a more liberal and republican way. ${ }^{453}$

The royal veto on constitutional amendments was a bastion for royalists. At the other end of the line one, several municipalities petitioned the National Assembly in March 1849 that the executive should be excluded from participating in the process of constitutional revision. ${ }^{454}$ The non-integration of the crown into the amendment process was not a position held by the majority, and the Imperial Constitution included the king's right to a suspensive veto on constitutional amendments or modifications. 'Suspensive' meant, in this case, that the parliament could overcome the veto of the king in three successive sessions. ${ }^{455}$ This was a thorn in David Hansemann's side. According to him, it revealed the 'true' constituent intention to establish a republic 'hiding behind the title of a monarchy. ${ }^{456}$ Because of this, the Prussian government insisted on an absolute veto, which it believed was necessary in the enacting, abolishing, and amending of law. ${ }^{457}$

The voices in favour of a suspensive veto met in their assessment for a necessary balance between parliament and monarch. The issue of a veto had been raised in the pages of the Deutsches Volksblatt as early as December 1848, in which the author pointed out that the question of the veto was neither a question of the divine right of kings nor liberty, but rather a simple question of power. Indeed, the parliamentarian Friedrich Dahlmann had defended the instrument of the veto in the German

\footnotetext{
452،"Zur Verfassungsfrage Deutschlands XI”, Deutsche constitutionelle Zeitung, No. 45, 22 February 1849.

${ }^{453}$ Hansemann, David (1849), Die deutsche Verfassung, 63-4.

454“"Adressen an die Nationalversammlung in Betreff der Oberhauptsfrage und der Verfassung", Deutsche Reichstags-Zeitung, No. 66, 19 March 1849: 'Veränderungen in der Verfassung des Reichs wie der Einzelstaaten dagegen der Zustimmung der Exekutivgewalt gänzlich entnommen.' ${ }^{455}$ Verfassung des deutschen Reiches (28 March 1848), $§ 196$, in Willoweit and Seif (=Müßig) (2003), 587-8.

${ }^{456}$ Hansemann, David (1849), Die deutsche Verfassung, 64.

457“"Deutschland, Frankfurt am Main”, Deutsche Reform, No. 172, supplement, 5 March 1849: ' $\S$ 18 Es muss darauf bestanden werden, dass das Bundesoberhaupt das Recht des absoluten Veto habe. Demgemäß würde § 18 etwa wie folgt zu fassen sein: Zur Erlassung, Auslegung, Aufhebung oder Abänderung von Bundesgesetzen ist die Übereinstimmung des Bundsoberhauptes, des Staatenhauses und des Volkshauses erforderlich.'
} 
National Assembly by saying that England's political situation would be better if the instrument of the veto would nowadays not be practically impossible. There was no other option than implementing a veto - the examples of Norway and North America showed that the alternative would be only a delay of requests. ${ }^{458}$ The instrument of the veto was also generally supported by the National-Zeitung. One correspondent to this newspaper disapproved of an absolute veto, on the grounds that it would in fact weaken, rather than strengthen, the position of the king. Again, the English example was pertinent, as the monarchy's power of absolute veto had become so impractical that it had fallen into complete disuse. On the other hand, the example of Norway showed that a suspensive veto provided a reasonable avenue to deal with overhasty decisions of the parliament. In this argument, though, the newspaper distinguished between the territorial states and the federal state. In the territorial states, the king should have the right of a two-times suspensive veto, while in the federal state the king should just hold the right for a single suspensive veto. The reason for this lay in the position of the king and the role he played in the body politic. In the federal state, the king would not be the sovereign; rather, he would simply be the highest executive organ. ${ }^{459}$

This opinion was also followed by Johann Gottlieb Kuechler, who also argued that an absolute veto damaged the venerability of the king. An absolute veto implied that the dignity and will of the people could be disregarded by the king using an arbitrary prerogative. In doing so, it therefore alienated the person of the king from the will of the population, thereby affecting the prestige of his position, and the love and esteem in which he was held. The absolute veto, in other words, was not a symbol of the dignity of the king. Kuechler's solution, like that of the proprietors of the National-Zeitung, was the suspensive veto, which would confirm the king's position as the highest power in the state, while also ensuring that this power was subject to existing laws that the king has to observe. The examples of

\footnotetext{
458“"Frankfurt 14. Dez", Deutsches Volksblatt, eine politische Zeitung, No. 206, 17 December 1848: 'Das Veto ist in England seit der Königin Anna nicht angewendet, allein es würde in mancher Beziehung besser stehen, wenn dessen Anwendung durch die Verhältnisse nicht praktisch unmöglich geworden wäre. [...] Es ist keine Freiheits- oder Gottes-Gnaden-Frage, sondern eine Machtfrage.' The Deutsches Volksblatt was a political newspaper, catering to the Catholic population of the Kingdom of Württemberg. It existed from 1848 until 1935/1965.

459"Die Deutsche Verfassung IV", National-Zeitung, No. 40, 12 May 1848: 'Wie Englands Beispiel beweist [...] ist bei dem jetzigen Stand der Dinge das absolute Veto nur ein nominelles, in der That nicht ausübbares Recht [...] Hiergegen sichert das supensive Veto der Krone, welches bei seiner Ausübung das Volk nicht verletzt, und daher, wie Norwegen zeigt, zum Heile des Landes angewendet [werden] kann und angewendet wird. [...] Ein zweimaliges Veto sichert der Krone somit eine größere Macht, und erhält vollkommen die organische Verbindung zwischen der gesetzgebenden und der ausübenden Gewalt. [...] Der Kaiser ist nicht der Träger der Rechtsidee, nicht der Souverain, sondern nur die ausführende höchste Behörde.'
} 
North America, Norway, and Brazil had amply demonstrated that the suspensive veto was both useful and reasonable, and made hasty and ill-considered decisions (both on the part of the legislature and the executive) impossible. ${ }^{460}$ Thus, as Kuechler conceived it, the suspensive veto served a dual purpose. Pragmatically, it offered a reasonable monarchical check and balance to parliamentarianism, much as the constitution itself was a popular check and balance on monarchical power. Beyond this, it would help to cement the image of the king as a benevolent but not omnipotent leader, working in the best interests of his subjects.

The purpose of the ReConFort project has been to investigate European constitutional heritage. However, in this sketch of the German case study, the project has also opened new avenues of research and inquiry. The American and French discourses are necessary for understanding the contributions in this volume regarding the Belgian, Italian, and Polish case studies, but even in the necessarily brief discussion of the German example presented here, it is clear that there are heretofore unrecognised patterns of continuity and conformity, as well as adaptation to local conditions. The American 'invention' of the judicial review and the French reluctance to limit the legislative consent representing the continuous sovereignty of the people provided European formulations of constitutional precedence with both positive and negative poles; what Hansemann, Gagern, and their compatriots in the St. Paul's Assembly demonstrated was that there was still a spectrum in between those poles, in which political and judicial actors and constitutional theorists would attempt to set their own course. The form that this course took, and the influences upon it, provide us with further insight into the development of Europe's 'community' of constitutionalism, and it is these elements that promise and afford further opportunities for research.

\section{Conclusion}

In 1782, Charles Thomson found inspiration in Virgil's Eclogue IV, when he sketched his unfinished pyramid and proclaimed the Novus Ordo Seclorum for the newly-founded United States of America. Thomson's choice of expression implied a clean break from Europe and the birth of a new society unencumbered by Europe's old iniquities. Four decades later, Johann Wolfgang von Goethe believed that America's 'new order' had succeeded, when he lamented Europe's continued 'useless remembering and unrewarding strife.'

\footnotetext{
${ }^{460}$ Kuechler, J. G. K. E., (1850), Über die Reichsverfassungsfrage und das Reichswahlgesetz, 43: 'Das Recht des absoluten Veto ist aber zur Erhaltung der Würde des Reichsoberhauptes nicht nur unnöthig, sondern es kann jenes Recht auch diese Würde und das Ansehen des Reichsoberhauptes die Liebe und Anhänglichkeit zu demselben, und damit auch dessen Wirksamkeit bis aufs Äußerste gefährden, während das Suspensivveto in den nordamerikanischen Freistaaten, dem Königreich Norwegen und dem Kaiserreich Brasilien sich nicht nur als ganz unschädlich gezeigt, Ueberstürzungen unmöglich gemacht [...] als angemessen und nützlich erwiesen hat.'
} 
As it turns out, neither was entirely correct. The 'new order' ushered in an unprecedented constitutional experiment, but one which borrowed liberally from the precedent of the Old World. Nor — in spite of Goethe's pessimism - was Europe unwilling (or unable) to learn. Remembrance, in this case, was hardly as 'useless' as Goethe imagined, and constitutional theorists and practitioners of nineteenth-century Europe looked to historical examples for their own inspiration. This amounted not necessarily to a preoccupation, but more to a desire to avoid the mistakes of the past by learning from them. Emmanuel Joseph Sieyès and Antoine-Claire Thibaudeau, for example, were opponents whose clashes in the French National Convention appear to have been irreconcilable; certainly, they were never able to resolve these differences before the Revolution was overtaken by Bonapartism and embarked on a new course. However, though their approaches differed, fundamentally they were addressing the same questions: who does a constitution serve? How does it do so? How can the integrity of the constitution be maintained? Most ambitious of all: what is a constitution in the pantheon of law and order, politics and society? These were the same questions posed to and by James Madison, Alexander Hamilton, and the American constitutionalists at the end of the nineteenth century, and they were the same questions debated in St. Paul's Church in Frankfurt in 1848 and 1849. Though the specific circumstances and contexts have changed, they are also, at a basic level, the questions facing western liberal democracy as a whole, and the European Union in particular, as we near the end of the first fifth of the twenty-first century.

If we return to Virgil's Eclogue, we find not just an appeal to a 'new order of ages', but also the prophecy of the Cumaean Sibyl:

Now the last age by Cumae's Sibyl sung

Has come and gone, and the majestic roll

Of circling centuries begins anew:

Justice returns, returns old Saturn's reign,

With a new breed of men sent down from heaven.

Only do thou, at the boy's birth in whom

The iron shall cease, the golden age arise. ${ }^{461}$

Thomson believed Virgil's words to be an appropriate conception of his new society; here, too, the Sybil's prognosis appears prophetic in light of the challenges facing the European Union today. Thomson's unfinished pyramid, in its original iteration, symbolised the absence of the monarch in the new American system, but it can also be read as an indicator, in the words of Barack Obama, that '[t]he unfinished work of perfecting our union falls to each of us. ${ }^{462}$ This sentiment is as applicable to Europe as it is to the United States.

\footnotetext{
${ }^{461}$ Virgil, "Eclogue IV", in Virgil (2005), 11.

${ }^{462}$ Obama's Letter To His Daughters.
} 
The enduring lesson of ReConFort is not one of 'useless remembering', as Goethe has phrased it in his poem To the United States, but rather that remembering serves a purpose in opening a window on to the challenges and opportunities faced by the European Union now and in the future. The individual member states of the Union have their own, unique contexts and complexities. Yet it is also true that European constitutionalism shares certain commonalities - even when that definition of 'Europe' extended to settlement away from the Old World, and even when that constitutionalism was a concerted attempt to break away from Europe. By acknowledging these commonalities, and by investigating their histories, ReConFort provides a greater framework for understanding the present day. In this way, ReConFort is a further stone in the gradual construction of Europe's own incomplete pyramid and, it is to be hoped, a contribution to the 'unfinished work of perfecting our union.'

\section{References}

Achanier (n.d.) Entwurf zu einer deutschen Verfassung. Frankfurt am Main

Adams CF (ed) (1851) The works of John Adams, Second President of the United States, vol III. Charles C. Little and James Brown, Boston

Adams WP (1973) Republikanische Verfassung und bürgerliche Freiheit. Die Verfassungen und politischen Ideen der amerikanischen Revolution. Luchterhand, Darmstadt and Neuwied

Angermann E (1966) "Hansemann, David”. Neue Deutsche Biographie 7:626-629

Aquinas Thomas (1892) Prima secundae Summae theologiae a quaestione 71 ad quaestionem 114, opera omnia. Tomus VII. ex. Typog. Polyglotta, Rome

Arendt H (1963) On revolution. Faber \& Faber, New York

Armitage D (2002) The declaration of independence and international law. William Mary Q 59:39-45

Avril P (2005) Le Conseil constitutionnel. Montchrestien, Paris

Azimi V (1998) L'impossible révision de la Constitution: l'exemple de l'an III. In: Bart J, et al (eds) La Constitution de l'an III ou l'ordre républicain. Éditions universitaire de Dijon, Dijon, pp 199-211

Bach A (n.d.) Umriß einer Staatsverfassung für Deutschland, Der hohen constituierenden Nationalversammlung zu Frankfurt ehrfurchtsvoll gewidmet

Baczko B (1989) Comment sortir de la Terreur? Thermidor et la Révolution. Gallimard, Paris

Baczko B (1997) Job, mon ami: promesses du bonheur et fatalité du mal. Gallimard, Paris

Badura P (1973) Verfassung und Verfassungsgesetz. In: Ehmke H et al (eds) Festschrift für Ulrich Scheuner zum 70. Geburtstag. Duncker \& Humblot, Berlin, pp 19-40

Badura P (1992a) Arten der Verfassungsrechtssätze. In: Isensee J, Kirchhof P (eds) Handbuch des Staatsrechts der Bundesrepublik Deutschland, vol VII: Normativität und Schutz der Verfassung: internationale Beziehungen. Müller, Heidelberg, pp 33-56

Badura P (1992b) Verfassungsänderung, Verfassungswandel, Verfassungsgewohnheitsrecht. In: Isensee J, Kirchhof P (eds) Handbuch des Staatsrechts der Bundesrepublik Deutschland, vol VII: Normativität und Schutz der Verfassung: internationale Beziehungen. Müller, Heidelberg, pp 57-78

Bailyn B (ed) (1965) Pamphlets of the American revolution, 1750-1776, vol I: 1750-1765. Harvard University Press, Cambridge 
Bailyn B (1967) The ideological origins of the American Revolution. Harvard University Press, Cambridge

Bailyn B (ed) (1993) The debate on the constitution: federalist and antifederalist speeches, articles and letters during the struggle over ratification, 2 vols. Library of America, New York

Baker JH (1979) Manual of Law French. Avebury, London

Baker JH (1986) The legal profession and the common law: historical essays. Hambledon, London and Ronceverte, WV

Baldwin EH (1902a) Joseph Galloway, the Loyalist Politician. Pa Mag Hist Biogr 26(2):161-191

Baldwin EH (1902b) Joseph Galloway, the Loyalist Politician. Pa Mag Hist Biogr 26(3):289-321

Baldwin EH (1902c) Joseph Galloway, the Loyalist Politician. Pa Mag Hist Biogr 26(4):417-442

Bart J et al (eds) (1998) La Constitution de l'an III ou l'ordre républicain. Éditions universitaire de Dijon, Dijon

Bastid P (1939) Les discours de Sieyès dans les débats constitutionnels de l'an III (2 et 18 Thermidor). Hachette, Paris

Bastid P (1970) Sieyès et sa pensée. Hachette, Paris

Battaglini M (1957) Contributi alla storia del controllo di costituzionalità delle leggi. Giuffrè, Milan

Bayer E (1849) Die Grundrechte und die Reichsverfassung für Deutschland, beleuchtet von einem Bayer. Augsburg

Beke-Martos J (2012) Transferring the presidential power-historic overview of the U.S. Presidential Inaugurations. Revista Aequitas 2:155-174

Berbig R (2000) Theodor Fontane im literarischen Leben: Zeitungen und Zeitschriften, Verlage und Vereine. De Gruyter, Berlin

Bernatzik E (ed) (1911) Die österreichischen Verfassungsgesetze mit Erläuterungen, vol II. Manz, Vienna

Bernstein, RJ (2017) The current global resurgence of pragmatism. Lecture at the Katholische Akademie in Bayern, Munich, 21 Mar 2017

Blackstone W (1979) Commentaries on the Laws of England, vol I: of the rights of persons. University of Chicago Press, Chicago

Bland R (1764) The colonel dismounted

Bland R (1766) An inquiry into the rights of the British Colonies

Bockenförde EW (2000) Le droit, l'Etat et la Constitution democratique. LGDJ, Paris

Bolingbroke HSJ (1749) Letters, on the spirit of patriotism, on the idea of a patriot king, and on the state of parties, at the accession of King George the First. London

Bolingbroke HSJ (1754) A Dissertation upon parties. London

Bourdon J (1942) La Constitution de l'an VIII. Carrère, Rodez

Boyd JP (ed) (1964) Fundamental Laws and Constitutions of New Jersey 1664-1961. Van Nostrand, Princeton

Braniß CJ (1848) Die deutsche National-Verfassung und die preußische Constitution. Ein Votum, Breslau

Bredin J-D (1988) Sieyès. La clé de la Révolution française. Éditions de Fallois, Paris

Breen TH (1998) Subjecthood and citizenship: the context of James Otis's radical critique of John Locke. N Engl Q 71(3):378-403

Brunel F (1985) Aux origines d'un parti de l'ordre: les projets de Constitution de l'an III. In: Nicolas J (ed) Mouvements populaires et conscience sociale, XVIe-XIXe siècle. Presses du Palais Royal, Paris, pp 687-696

Bruun E, Crosby J (eds) (1999) Our nation's archive: the history of the United States in documents. Black Dog \& Leventhal, New York

Burgess G (1992) The politics of the ancient constitution: an introduction to English Political thought 1603-1642. Macmillan, London

Burke E (eds) (1826) The works of the right honourable Edmund Burke, vol III. C. \& J. Rivington, London

Cantor NF (1997) Imagining the law-common law and the foundations of the American Legal system. HarperCollins, New York 
Cappelletti M (1968) II controllo giudiziario di costituzionalità delle leggi nel diritto comparato. Giuffrè, Milan

Carrese PO (2003) Cloaking of power. University of Chicago Press, Chicago

Carter L (1965) The diary of colonel Landon Carter of Sabine Hall, 1752-1778. In: Greene JP (ed) Virginia Historical Society, Charlottesville

Cayla O (2006) L'obscure théorie du pouvoir constituant originaire ou l'illusion d'une identité souveraine inaltérable. In: de Béchillon D et al (eds) L'architecture du droit. Mélanges en l'honneur de Michel Troper. Economica, Paris, pp 249-65

Cicero Marcus Tullius (1959) De legibus libri tres. In: Keyes CW (ed). Heinemann, London

Clavreul C (1982) L'influence de la théorie d'Emmanuel Sieyès sur les origines de la représentation en droit public. Ph.D. diss., University of Paris I

Clemens R (ed) (1985) Die sibyllinischen Orakel, Die Aussprüche und Weissagungen der alten Sibylle über die Vergangenheit, Gegenwart und Zukunft der Welt, Aus alten Schriften in deutscher Übertragung mit Einleitung und erläuternden Anmerkungen, 2nd edn. Fourier, Wiesbaden

Coke E (1794) The first part of the Institutes of the Laws of England, or, a commentary upon Littleton, vol I, 15th ed. Charles Butler and Francis Hargrave, London

Coke E (1797) The Institutes of the Law of England, second to fourth parts. E. \& R. Brooke, London

Coke E (1826) The reports of Sir Edward Coke. In: Thomas JH, Fraser JF (eds) Joseph Butterworth \& Son, London

Conac G, Machelon J-P (1999) La Constitution de l'an III. Boissy d'Anglas et la naissance du libéralisme constitutionnel. Paris, PUF

Connor HG (1912) James Iredell: Lawyer, Statesman, Judge, 1751-1799. Univ Pa Law Rev Am Law Regist 60:225-253

Crane VW (ed) (1950) Benjamin Franklin's Letters to the Press. University of North Carolina Press, Chapel Hill

Crompton R (1637) L'authoritie et jurisdiction des courts de la Majeste de la Roigne, London

Cushing HA (ed) (1904/1906) The writings of Samuel Adams, 2 vols. G.P. Putnam, London

"Denis Toussaint Lesage" (2017) Assemblée Nationale. http://www2.assemblee-nationale.fr/ sycomore/fiche/\%28num_dept\%29/13121. Accessed 23 May 2017

Der Volksfreund, 1848-9

Deutsche allgemeine Zeitung, 1848

Deutsche constitutionelle Zeitung, 1848-9

Deutsche Reform, 1848-9

Deutsche Reichstags-Zeitung, 1848-9

Deutsche Zeitung, 1848

Deutsches Volksblatt, eine politische Zeitung, 1848

Di Donato F (2004) II giudizio di costituzionalità nella Francia d'Ancien Régime: una storia politico-istituzionale. Parte prima. Fondamenti teorico-pratici. Giornale di Storia Cost IV:147-65

Di Donato F (2005) II giudizio di costituzionalità nella Francia d'Ancien Régime: una storia politico-istituzionale. Parte seconda. Le dinamiche della prassi. Giornale di Storia Cost V:6586

Diamond AS (1976) The anti-federalist 'Brutus'. Polit Sci Rev 6:249-281

Dippel H (1987) Die Sicherung der Freiheit. Limited government versus Volkssouveränität in den frühen USA. In: Birtsch G (ed) Grund- und Freiheitsrechte von der ständischen zur spätbürgerlichen Gesellschaft. Vandenhoeck \& Ruprecht, Göttingen, pp 135-57

Dippel H (1994) Die amerikanische Verfassung in Deutschland im 19. Jahrhundert. Das Dilemma von Politik und Staatsrecht. Keip Verlag, Goldbach

Dodderidge J (1631) The English Lawyer

Dodge AR, Koed BK (ed) (2005) Biographical Directory of the United States Congress 17742005: The Continental Congress September 5, 1774, to October 21, 1788, and the Congress of the United States, from the First to the One Hundred Eighth Congresses, March 4, 1789 to January 3, 2005 Inclusive. United States Government Printing Office, Washington, D.C. 
Doe N (1990) Fundamental authority in Late Medieval English Law. Cambridge University Press, Cambridge

Döring A (1903) "Braniß, Christian Julius". Allgemeine Deutsche Biographie 47:184

Dreier H (2007) Deutschland. In: von Bogdandy A, Villalón PC, Huber PM (eds) Manual Ius Publicum Europaeum, vol I: Grundlagen und Grundzüge staatlichen Verfassungsrechts. C.F. Müller, Heidelberg, pp 3-86

Dunn J (1969) The Politics of Locke in England and America in the Eighteenth Century. In: Yolton JW (ed) John Locke: problems and perspectives. A collection of new essays. Cambridge University Press, Cambridge, pp 45-80

Dworetz SM (1990) The Unvarnished Doctrine: Locke, Liberalism, and the American Revolution. Duke University Press, Durham, NC

Edmund M (ed) (1959) Prologue to revolution: sources and documents on the Stamp Act Crisis 1764-1766. University of North Carolina Press, Chapel Hill, NC

Ellis RE (1987) The Union at Risk. Jacksonian Democracy, States Rights and the Nullification Crisis. Oxford University Press, New York

Engel EC (1961) Über das Wesen der amerikanischen Revolution. In: Born KE (ed) Historische Forschungen und Probleme: Peter Rassow zum 70. Geburtstag dargebracht von Kollegen, Freunden und Schülern. F. Steiner, Wiesbaden, pp 194-215

Faller HJ (1974) Die Verfassungsgerichtsbarkeit in der Frankfurter Nationalversammlung. In: Leibholz G (ed) Menschenwürde und freiheitliche Rechtsordnung: Festschrift für Willi Geiger zum 65. Geburtstag. J.C.B. Mohr, Tübingen, pp 827-55

Farrand M (ed) (1911) The records of the Federal Convention of 1787, vol II. Yale University Press, New Haven

Fauré C (1999) Introduction à des manuscrits de Sieyès 1773-1799. Champion, Paris

Feuerbach PJA von (1833) Anselms von Feuerbach Kleine Schriften vermischten Inhalts. Otto, Nuremberg

Finch H (1759) A description of the common Laws of England

Fioravanti M (1999) Costituzione. Il Mulino, Bologna

Fioravanti M (2007) Sieyès et le jury constitutionnaire: perspectives historico-jurdiques. Ann Hist de la Révolut Fr 349:87-103

[Fitch T et al] (1764) Reasons why the British Colonies, in America, should not be charged with internal taxes.

Ford WC (ed) (1904) Journals of the continental congress, 1774-1789, vol I. Library of Congress, Washington, D.C.

Fortescue J (1997) In praise of the Laws of England. In: Fortescue J, Lockwood S (eds) On the Laws and Governance of England. Cambridge University Press, Cambridge, pp 1-81

Founding Fathers (2007) The essential guide to the men who made America, introduced by Joseph J. Ellis. Wiley, Hoboken, NJ (Enyclopædia Britannica)

Freie Volksblätter, 1848

Friedrich CJ (1953) Der Verfassungsstaat der Neuzeit. Springer, Berlin

Fröschl T (2014) Die 'Declaration of Independence' in Europa 1776-1815. Europäische Geschichte Online. http://ieg-ego.eu/de/threads/europaeische-medien/europaeischemedienereignisse/die-amerikanische-revolution-als-europaeisches-medienereignis/thomasfroeschl-die-declaration-of-independence-in-europa-1776-1815. Accessed 19 May 2017

Fröschl T (2015) Staatenbund und Völkerrecht in der Gründungsphase der Vereinigten Staaten. Der Staat, Beiheft 23: Verfassung und Völkerrecht in der Verfassungsgeschichte: 37-63

Gardiner SR (ed) (1906) The constitutional documents of the Puritan Revolution 1625-1660, 3rd edn. Clarendon, Oxford

Gauchet M (1995) La Révolution des pouvoirs. La souveraineté, le peuple et la représentation 1789-1799. Éditions Gallimard, Paris

Goethe JW von (1842) Zahme Xenien: Den vereinigten Staaten. In: von Goethe (ed) Nachgelassene Werke, vol XVI. Cotta, Stuttgart and Tübingen

Goethe JW von (1948) The United States. In: Mann T (ed) The Permanent Goethe (trans: Spender S). Dial, New York, p 655 
Gough JW (1961) Fundamental Law in English Constitutional History, Oxford University Press, New York

Gray CM (1980) Reason, authority and imagination: the Jurisprudence of Sir Edward Coke. In: Zagorin P (ed) Culture and politics from Puritanism to the Enlightenment. University of California Press, Berkeley, Los Angeles, and London, pp 25-66

Gray CM (1992) Parliament, liberty and the law. In: Hexter JH (ed) Parliament and liberty from the reign of Elizabeth to the English Civil War. Stanford University Press, Stanford, pp 85-121

Green VHH (1945) Bishop Reginald Pecock: a study in ecclesiastical history and thought. Cambridge University Press, Cambridge

Greene JP (1968) 'Not to be governed or taxed, but by...our representatives': four essays in opposition to the Stamp Act by Landon Carter. Va Mag Hist Biogr 76:259-300

Greene JP (2010) The constitutional origins of the American Revolution. Cambridge University Press, Cambridge

Grey TC (1978) Origins of the unwritten constitution: fundamental law, revolutionary thought. Stanford Law Rev 30(4):843-893

Griffith W (1843) Historical notes of the American Colonies and revolution: from 1754 to 1775. Burlington

Gummere RM (1956) John Dickinson, the Classical Penman of the Revolution. Class J 52(2):8188

Guy JA (1985) St. German on Chancery and Statute. Selden Society, London

Hamilton A, Madison J, Jay J (1961) The federalist papers. New American Library, New York

Hanbury HG (1950) Blackstone in retrospect. Law Q Rev 66:318-347

Hansemann D (1849) Die deutsche Verfassung vom 28. März 1849 mit Anmerkungen, 3rd edn. F. Schneider und Company, Berlin

Hartz L (1955) The liberal tradition in America. Harcourt Brace \& World, New York

[Hicks W] (1765) Considerations upon the rights of the colonies to the privileges of British subjects. New York

Higginbotham D (ed) (1976) The papers of James Iredell, vol II. Division of Archives and History, Department of Cultural Resources, Raleigh, N.C.

Hofmann H (2012) Einführung in die Rechts- und Staatsphilosophie. WBG, Darmstadt

Hopkins S (1765) The rights of the Colonies examined. Providence, RI

Horne A (1893) The Mirror of Justices. In: Whittaker WJ, Maitland, FW (eds). Selden Society, London

Hostettler J (1997) Sir Edward Coke, A Force for Freedom. Barry Rose Law Publishers, Chichester

Hourquebie F (2004) Sur l'émergence du contre-pouvoir juridictionnel sous la Vème République. Bruyland, Brussels

Huitt RK (1953-4) The constitutional ideas of James Otis. Univ Kansas Law Rev 2:152-73

Hume D (1788) Essays and treatises on several subjects in two volumes, containing essays, moral, political and literary, vol I. Cadell T, Elliot C, Kay T and Co., London

Hunt G (ed) (1906) The writings of James Madison, vol VI: correspondence, 1790-1802. G. P. Putnam \& Sons, New York

Hunt G (1917) The Virginia Declaration of Rights and Cardinal Bellarmine. Cathol Hist Rev III (3):276-89

Ives EW (1983) The common lawyers of pre-reformation England: Thomas Kebell: a case study. Cambridge University Press, Cambridge

Jaume L (2002) Sieyès et le sens du jury constitutionnaire: une reintérpretation. Droits XVIII (36): $115-134$

Jefferson T (1984) Writings. In: Peterson MD (ed) Library of the Americas, New York

Jezierski JV (1971) Parliament and people: James Wilson and Blackstone on the nature and location of sovereignty. J Hist Ideas 32:95-106

Johannsen RW (ed) (1965) The Lincoln-Douglas debates of 1858. Oxford University Press, New York 
Johnson TB (1812) An impartial history of Europe, from the Death of Louis XVI. To the present to which is prefixed, a sketch of the French revolution, vol II. Sherwood, Neely, and Jones, London

Kahl J (1972) National-Zeitung, Berlin (1848-1938). In: Fischer H-D (ed) Deutsche Zeitungen des 17. bis 20. Jahrhunderts, vol II. Verlag Dokumentation, Munich, 177-80

Kastari P (1966) Über die Normativität und den hierarchischen Vorrang der Verfassungen. In: Bracher KD et al (eds) Die moderne Demokratie und ihr Recht. Festschrift für Gerhard Leibholz zum 65. Geburtstag, vol II: Staats- und Verfassungsrecht. J.C.B. Mohr, Tübingen, pp 49-68

Kelly A, Harbison W (1970) The American constitution: its origins and development, 4th edn. W. W. Norton, New York

Klein C (1996) Théorie et pratique du pouvoir constituant. PUF, Paris

Klüber JL (1831) Öffentliches Recht des Teutschen Bundes und der Bundesstaaten, 2. Abtheilung enthaltend das Staatsrecht Teutscher Bundesstaaten, 3rd edn. Andreäische Buchhandlung Frankfurt a. M.

Klüber JL (1840) Öffentliches Recht des Teutschen Bundes und der Bundesstaaten, 2. Abtheilung enthaltend das Staatsrecht Teutscher Bundesstaaten, 4th edn. Andreäische Buchhandlung Frankfurt a. M.

[Knox W] (1765a, reprint Keip: 1970) A letter to a Member of Parliament, wherein the power of the British Legislature, and the case of the colonists are briefly and impartially considered. London

[Knox W] (1765b) The claim of the colonies to an exemption from internal taxes imposed by authority of Parliament, examined in a letter from a gentleman in London, to his friend in America. London

Kohnen R (1995) Pressepolitik des Deutschen Bundes: Methoden staatlicher Pressepolitik nach der Revolution 1848. Niemeyer, Tübingen

Kuechler JGKE (1850) Über die Reichsverfassungsfrage und das Reichswahlgesetz. Darmstadt

Ky HH (1926) Le contrôle de la constitutionnalité des lois en France. Pedone, Paris

Lacchè L (2000-2002) La garanzia della Costituzione. Riflessioni sul caso francese. Università degli studi di Macerata. Annali della facoltà di Giurisprudenza: 41-93

Lacchè L (2016) History \& constitution, developments in European constitutionalism: the comparative experience of Italy, France, Switzerland and Belgium (19th -20th centuries). Vittorio Klostermann, Frankfurt

Lambarde W (1619) Eirenarcha, or of the office of justices of peace

Laquièze A (2003) Le contrôle de constitutionnalité de la loi vu par les penseurs libéraux français du XX $X^{\mathrm{e}}$ siècle. In: Chagnollaud D (ed) Aux origines du contrôle de constitutionnalité, XVIII ${ }^{\mathrm{e}}$ $\mathrm{XX}^{\mathrm{e}}$ siècle. LGDJ, Paris, pp 85-102

Lefebvre G (1943) Le Directoire. CDU, Paris

Le Pillouer A (2005) Les pouvoirs non-constituants des Assemblées constituantes. Essai sur le pouvoir instituant. Dalloz, Paris

Lescuyer G (2001) Histoire des idées politiques. Dalloz, Paris

Lewis JU (1968) Sir Edward Coke (1552-1633): his theory of "Artificial Reason" as a context for modern basic legal theory. The Law Quarterly Review 84:330-342

Lieberman D (1989) The province of legislation determined, legal theory in eighteenth-century Britain. Cambridge University Press, Cambridge

Locke J (1963) The second treatise of government: an essay concerning the true original, extent, and end of civil government. In: Laslett P (ed). Cambridge University Press, Cambridge

Locke J (1989) A Letter Concerning Toleration: Latin and English Texts. In: Montuori M (ed). Marius Nijhoff, The Hague

Loewenstein K (1975) Verfassungslehre, 3rd edn. J.C.B. Mohr, Tübingen

Lucas P (1963) Ex Parte Sir William Blackstone 'Plagiarist': a note on blackstone and the natural law. Am J Leg Hist 7:142-158

Luzzatto S (2001) L'automne de la Révolution. Luttes et cultures politiques dans la France thermidorienne. Champion, Paris 
Macpherson CB (1990) Die politische Theorie des Besitzindividualismus von Hobbes bis Locke (trans: Wittekind A). Suhrkamp, Berlin

Mandeville J (1932) Mandeville's travels, vol II. In: Hamélius JP (ed). Early English Text Society, London

Manin B (1989) Les deux libéralismes. La règle et la balance. In: Biet C, Théry I (eds) La Famille, la Loi, l'État: De la Révolution au Code civil. Imprimerie nationale et Centre national d'art et de culture Georges-Pompidou, Paris, pp 372-89

Mansfield HC (1989) Taming the prince: the ambivalence of modern executive power. The Free Press, New York

Mathiez A (1934) Le Directoire. Colin, Paris

Mauduit J (1766) Legislative authority of the British Parliament, with respect to North America, and the privileges of the assemblies there, briefly considered. London

Maus D (2003) La naissance du contrôle de constitutionnalité des lois en France. In: L'esprit des institutions, l'équilibre des pouvoirs. Mélanges en l'honneur de Pierre Pactet. Dalloz, Paris

Maus D (2006) Nouveaux regards sur le contrôle de constitutionnalité par voie d'exception. In: de Béchillon D, Champeil-Desplats V, Brunet P, Millard E (eds) L'architecture du droit. Mélanges en l'honneur de Michel Troper. Economica, Paris, pp 665-78

McClain E (1913) Constituitional Law in the United States, 2nd ed. Longmans, Green and Co., New York

McPhee P (2012) Robespierre: a revolutionary life. Yale University Press, New Haven

Melis F (1998) Die Drucker der 'Neuen Rheinischen Zeitung'. Zum unvorhergesehenen Wechsel der Druckerei im Sommer 1848. In: Schmidt W (ed) Demokratie, Liberalismus und Konterrevolution: Studien zur deutschen Revolution von 1848/49. Fides, Berlin, pp 273-326

Mestre J-L (2010) Les contrôles judiciaires a posteriori de constitutionnalité à partir de la Révolution. Cahiers du Conseil constitutionnel 28, dossier 'L'histoire du contrôle de constitutionnalité'. http://www.conseil-constitutionnel.fr/conseil-constitutionnel/francais/ nouveaux-cahiers-du-conseil/cahier-n-28/les-controles-judiciaires-a-posteriori-deconstitutionnalite-a-partir-de-la-revolution.52719.html. Accessed 19 Apr 2017

Mims E Jr (1941) The majority of the people. Modern Age Books, New York

Mohnhaupt H (1982), Die Lehre von der "Lex fundamentalis" und die Hausgesetzgebung europäischer Dynastien. In: Kunisch J, Neuhaus H (eds) Der dynastische Fürstenstaat. Zur Bedeutung von Sukzessionsordnungen für die Entstehung des frühmodernen Staates, Duncker \& Humblot, Berlin

Mohnhaupt H (1998) Von den "leges fundamentalis" zur modernen Verfassung in Europa. Zum begriffs-u. dogmengeschichtlichen Befund (16-18. Jahrhundert). In: Simon D and Stolleis M, luscommune, vol. XXV, Vittorio Klostermann, Frankfurt am Main, 121-158

Mohnhaupt H (2011) Reichsgrundgesetze als Verfassung im System des Lus publicum. In: Dilcher G and Quaglioni D (eds.), Gli inizi del diritto pubblico III. Die Anfänge des öffentlichen Rechts III, Societa editrice il Mulino / Duncker \& Humbolt, Bologna / Berlin, $697-724$

Mohnhaupt H, Grimm D (2002) Verfassung: Zur Geschichte des Begriffs von der Antike bis zur Gegenwart, 2nd edn. Duncker \& Humblot, Berlin

Moniteur, an III (1795)

Moniteur Universel (1842) Reímpression de l'Ancien Moniteur, vol XXV. Paris

Montesquieu Charles-Louis (1994) De l'Esprit des Lois. In: Euvres complètes, texte présenté et annoté par Roger Caillois, vol II, Gallimard, Paris

Morabito M (2002) Histoire constitutionnelle de la France (1789-1958). Montchrestien, Paris

Mosse GL (1950) The struggle for sovereignty in England: from the reign of Queen Elizabeth to the right of petition. Michigan State Press, East Lansing

Muß F (2013) Präsident und Ersatzmonarch. Die Erfindung des Präsidenten als Ersatzmonarch in der amerikanischen Verfassungsdebatte und Verfassungspraxis. Herbert Utz Verlag, Munich

Müßig U (2006a) Die englischen Verfassungskämpfe des 17. Jahrhunderts. In: Müßig U (ed) Konstitutionalismus und Verfassungskonflikt: Symposium für Dietmar Willoweit. Mohr Siebeck, Tübingen, pp 37-60 
Müßig U (2006b) Konflikt und Verfassung. In: Müßig U (ed) Konstitutionalismus und Verfassungskonflikt: Symposium für Dietmar Willoweit. Mohr Siebeck, Tübingen, pp 1-28

Müßig U (2008a) Coke, Edward. In: Handwörterbuch zur deutschen Rechtsgeschichte, vol I, 2nd edn. Schmidt, Berlin

Müßig U (2008b) Constitutional conflicts in seventeenth-century England. Tijdschrift voor Rechtsgeschiedenis 76:27-47

Müßig U (2008c) Die europäische Verfassungsdiskussion des 18. Jahrhunderts. Mohr Siebeck, Tübingen

Müßig U (2009) Recht und Justizhoheit: Der gesetzliche Richter im historischen Vergleich von der Kanonistik bis zur Europäischen Menschenrechtskonvention, unter besonderer Berücksichtigung der Rechtsentwicklung in Deutschland, England und Frankreich, 2nd edn. Duncker \& Humblot, Berlin

Müßig U (2013a) Montesquieu's Mixed Monarchy Model and the Indecisiveness of the 19th Century Constitutionalism between Monarchical and Popular Sovereignty. Historia et ius 3: paper 5. http://www.historiaetius.eu/uploads/5/9/4/8/5948821/mussig_finale.pdf. Accessed 22 May 2017

Müßig U (2013b) Summum ius, summa iniuria - Zur Korrekturbedürftigkeit des strengen Rechts in deutschen und englischen Rechtsquellen. In: Müßig U (ed) Ungerechtes Recht. Mohr Siebeck, Tübingen, pp 23-65

Müßig U (2014) Locke, John. In: Handwörterbuch zur deutschen Rechtsgeschichte, vol III, 2nd edn. Schmidt, Berlin

Müßig U (2016) Juridification by constitution, national sovereignty in eighteenth and nineteenth century Europe. In: Müßig U (ed) Reconsidering constitutional formation, vol. I: national sovereignty: a comparative analysis of the juridification by constitution. Springer, Cham

Müßig U (2017) Networkers of the Constitutional Discourses of the 18th c. Europe - The British-American discursive common law community, paper at the 23rd British Legal History Conference (Networks and Connections), London

Nadelhaft J (1966) The somersett case and slavery: myth, reality, and repercussions. J Negro Hist 51(3):193-201

National-Zeitung, 1848

Negri A (1997) Le pouvoir constituant. Essai sur les alternatives de la modernite. PUF, Paris

Neue Münchener Zeitung, 1849

Nicolle B (1990) Aux origines du contrôle de constitutionnalité. La jurie constitutionnaire de Sieyes (1795). University of Paris X-Nanterre, Mémoire de DEA

N.N. (1765a) The Political Balance, in which the Principles and Conduct of the Two Parties are Weighed. London

N.N. (1765b) A Vindication of the Rights of the Americans. London

N.N. (1766) The General Opposition of the Colonies to the Payment of the Stamp Duty. Printed for T. Payne, London

Nowak JE, Rotunda RD (1991) Constitutional law, 4th edn. West, St. Paul, MN

Noy W (1641) A Treatise of the Principal Grounds and Maxims of the Laws of this Kingdom

Obama B (2009) A letter to my daughters. Parade. https://parade.com/37592/parade/Barackobama-a-letter-to-my-daughters/. Accessed 22 May 2017

Otis J (1764) Rights of the British Colonies asserted and proved. Edes and Gill, Boston

Paley W (1825) The principles of moral and political philosophy. In: Paley E (ed) The works of William Paley, vol IV. C. \& J. Rivington, London

Papatolias A (2000) Conception mécaniste et conception normative de la Constitution. LGDJ, Paris

Pasquino P (1998) Sieyès et l'invention de la Constitution en France. Éditions Odile Jacob, Paris

Pate JE (1931) Richard Bland's Inquiry into the Rights of the British Colonies. William and Mary Q 11(1):20-28

Pecock R (1924) The folower to the Donet. Early English Text Society, London

Pertué M (1976) Aux origines du gouvernement Révolutionnaire (février 1793-mars 1793):

Démocratie et Dictature en Révolution. Ph.D. diss., University of Paris-II 
Pertué M (1989) La Constitution de l'an VIII. In: Soboul A (ed) Dictionnaire historique de la Révolution française. PUF, Paris, pp 286-287

Pertué M (2003) La notion de Constitution à la fin du 18e siècle. In: Guilhaumou J, Monnier R (eds) Des notions concepts en révolution: autour de la liberté politique à la fin du 18e siècle, vol IV: des Études révolutionnaires. Société des études robespierristes, Paris, pp 39-54

Pfeiffer BW (1831) Practische Ausführungen aus allen Theilen der Rechtswissenschaft, Mit Erkenntnissen des Oberappellationsgerichts zu Cassel, vol III. Hahn, Hannover

Pitt W (2014) Die Brockhaus Enzyklopädie Online. https://brockhaus.de/sites/default/files/ pdfpermlink/pitt-william-73e49415.pdf. Accessed 14 March 2017

Plucknett TFT (1926/27) Bonham's case and judicial review. Harvard Law Rev 40:30-70

Pollock F, Maitland FW (1952) The history of english law before the time of Edward I, vol I, 2nd edn. Cambridge University Press, Cambridge

Ponteil F (1954) Le régime autoritaire et les grandes lois organiques de l'an VIII. Revue internationale d'histoire politique et constitutionnelle IV:226-43

Prest WR (1977) The dialectical origins of Finch's Law. Camb Law J 36:326-352

Reichsgesetzblatt für das Kaiserthum Österreich, 1869

Reid JP (1974) In a defensive rage: the uses of the mob, the justification in law, and the coming of the American Revolution. N Y Univ Law Rev 49:1043-1091

Reid JP (1976) In accordance with usage: the authority of custom, the stamp act debate, and the coming of the American Revolution. Fordham Law Rev 45(2):335-368

Reid JP (1981) The irrelevance of the declaration. In: Hartog H (ed) Law in the American Revolution and the revolution in the law. New York University Press, New York, pp 46-89

Reid JP (1995) Constitutional history of the American Revolution. University of Wisconsin Press, Madison

Riggs LH (1946) Daniel Dulany II. Law Libr J 39:8-15

Rjals S (1991) Sieyès ou la délibération sans la prudence. Éléments pour une interprétation de la philosophie de la Révolution et de l'esprit du légicentrisme. Droits VII 1:123-138

Ruppert S, Schorkopf F (2015) § 90 Abs. 1 BVerfGG, Zulässigkeit der Verfassungsbeschwerde. In: Burkiczak C, Dollinger FW, Schorkopf F (eds) Bundesverfassungsgerichtsgesetz (Heidelberger Kommentar). C.F. Müller, Heidelberg, pp 1402-1535

Rutherforth T (1862) Institutes of natural law: being the substance of a course of lectures on Grotius De Jure Belli et Pacis. Ticknor \& Fields, Boston

Ryberg IS (1958) Vergil's golden age. Trans Proc Am Philol Assoc 89:112-131

St. German C (1974) Dialogue between a Doctor of divinity and a student of the common law of England. In: Plucknett TFT, Barton JL (eds). Selden Society, London

Samuelson RA (1999) The constitutional sanity of James Otis: resistance leader and loyal subject. Rev Polit 61(3):493-523

Schmidt CH (2000) Vorrang der Verfassung und konstitutionelle Monarchie. Duncker \& Humblot, Berlin

Schmitt C (1929) Der Hüter der Verfassung. Archiv des öffentlichen Rechts XVI:161-267

Schmitt C (1931) Der Hüter der Verfassung. Mohr, Tübingen

Schultz D (1993) Political theory and legal history: conflicting depictions of property in the American political founding. Am J Leg Hist 37(4):464-495

Seif (=Müßig) U (2003a) Die europäische Rechtsprechung zwischen 'interprétation', 'Rechtsfortbildung' und 'case law'. In: Schulze R, Seif (=Müßig) U (eds) Richterrecht und Rechtsfortbildung in der Europäischen Rechtsgemeinschaft. Mohr Siebeck, Tübingen, pp 1-23

Seif (=Müßig) U (2003b) Recht und Gerechtigkeit: Die Garantie des gesetzlichen Richters und die Gewaltenteilungskonzeptionen des 17.-19. Jahrhunderts. Der Staat 42:110-40

Seif (=Müßig) U (2008) Blackstone, William. In: Handwörterbuch zur deutschen Rechtsgeschichte, vol I, 2nd edn. Schmidt, Berlin

Seydel M von (1885) Bayerisches Staatsrecht, vol II. Theodor Riedel, Munich.

Shaw T (1926) The Enlightenment of Lord Mansfield. J Comp Legis Int Law 8(1):1-8

Sieyès EJ (1970) Que'est-ce que le Tiers état? Droz, Geneva 
Simmons RC, Thomas PDG (eds) (1983) Proceedings and debates of the British Parliaments respecting North America, 1754-1776, vol II. Kraus, Millwood

Smith ST (1982) In: Mary D (ed) De Republica Anglorum. Cambridge Studies in the History and Theory of Politics, Cambridge

Smith DA (2011) Tax crusaders and the politics of direct democracy. Routledge, New York

Sommerville JP (1986) Politics and ideology in England 1603-1640. Longman, London

Starck C (1992) Die Verfassungsauslegung. In: Isensee J, Paul K (eds) Handbuch des Staatsrechts der Bundesrepublik Deutschland, vol VII: Normativität und Schutz der Verfassung: internationale Beziehungen. Müller, Heidelberg, pp 189-230

Stein P (1966) Regulae iuris: from juristic rules to legal maxims. University Press, Edinburgh

Stern K (1984) Grundideen europäisch-amerikanischer Verfassungsstaatlichkeit. Walter de Gruyter, Berlin

Stimson FJ (2004) The Law of the Federal and State Constitutions of the United States, with an historical study of their principles, a chronological table of English social legislation and a comparative digest of the constitutions of the forty-six-states. Lawbook Exchange, Clark

Stolleis M (2001) Public Law in Germany 1800-1914. Berghahn, New York

Stoner JR (1992) Common law and liberal theory - Coke, Hobbes, and the Origins of American Constitutionalism. University Press of Kansas Press, Lawrence

Storing HJ (ed) (1981) The complete anti-federalist, vol II. University of Chicago Press, Chicago

Stourzh G (1976) Die Konstituierung der Individualrechte: Zum 200. Jahrestag der 'Declaration of Rights' von Virginia vom 12. Juni 1776. Juristenzeitung 31:397-402

Stourzh G (1985) Die Gleichberechtigung der Nationalitäten in der Verfassung und Verwaltung Österreichs 1848-1918. Verlag der Österreichischen Akademie der Wissenschaften, Vienna

Stourzh G (1988) Constitution: Changing Meanings of the Term from the Early Seventeenth to the Late Eighteenth Century. In: Ball T, Pocock JGA (eds) Conceptual change and the constitution. University of Kansas Press, Lawrence, pp 35-54

Stourzh G (1989) Vom Widerstandsrecht zur Verfassungsgerichtsbarkeit: Zum Problem der Verfassungswidrigkeit im 18. Jahrhundert. In: Stourzh G (ed) Wege zur Grundrechtsdemokratie. Böhlau, Vienna

Stourzh G (1999) Liberal democracy as culture of rights-England, the United States, and Continental Europe. In: Fröschl T, Grandner M, Bader-Zaar B (eds) Nordamerikastudien: Historische und literaturwissenschaftliche Forschungen aus österreichischen Universitäten zu den Vereinigten Staaten und Kanada. Verlag für Geschichte und Politik, Vienna, pp 11-27

Stourzh G (2007) From Vienna to Chicago and back: essays on intellectual history and political thought in Europe and America. University of Chicago Press, Chicago

Stourzh G (2011) Verfassungsgerichtsbarkeit und Grundrechtsdemokratie - die historischen Wurzeln. In: Stourzh G (ed) Der Umfang der österreichischen Geschichte. Böhlau, Vienna, pp 157-179

Stourzh G (2015) Die moderne Isonomie, Menschenrechtsschutz und Demokratische Teilhabe als Gleichberechtigungsordnung. Böhlau, Vienna

Stubbs W (1905) Select charters and other illustrations of English constitutional history, 8th edn. Clarendon, Oxford

Sueur P (1989) Histoire du droit public français $X^{\mathrm{e}}-\mathrm{XVIII}^{\mathrm{e}}$ siècle. La genèse de l'État contemporain. 2. Affirmation et crise de l'État sous l'Ancien Régime. PUF, Paris

Swindler WF (ed) (1979) Sources and documents of United States constitutions, vol. X: Virginia, Washington, West Virginia, Wisconsin, Wyoming. Oceana, Dobbs Ferry

Thibaudeau A-C (1824) Mémoires sur la Convention et le Directoire, t. $1^{\text {er }}$ Convention. Baudoin, Paris

Thomas J (1915) Universal pronouncing dictionary of biography and mythology, 4th edn. J.B. Lippincott, Philadelphia

Timbal P-C, Castaldo A (2000) Histoire des institutions publiques et des faits sociaux. Dalloz, Paris

Töns U (1977) Sannazaros Arcadia. Wirkung und Wandlung der vergilischen Ekloge. Antike und Abendland 23:143-161 
Tripier L (ed) (1879) Constitutions qui ont régi la France depuis 1789 jusqu'à l'élection de M. Grévy comme Président de la République, 2nd edn. Larose, Paris

Troper M (1996) La Constitution de l'an III ou la continuité: la souveraineté populaire sous la Convention. In: Dupuy R, Morabito M (eds) 1795: Pour une République sans Révolution. PUR, Rennes, pp 179-92

Troper M (2001) Sieyès et le jury constitutionnaire. In: Ameller M (ed) La République. Mélanges en l'honneur de Pierre Avril. Montchrestien, Paris, pp 265-82

Troper M (2003) Le projet de Constitution europeenne et la question du pouvoir constituant. Cite XIII:101-11

Troper M (2006) Terminer la Révolution, La Constitution de 1795. Fayard, Paris

Tucker RW, Hendrickson DC (1982) The fall of the first British Empire: origins of the war of American independence. Johns Hopkins University Press, Baltimore

Tyrsenko A (2000) L'ordre politique chez Sieyès en l'an III. Annales historiques de la Révolution française LXXVII(1):27-45

Van Caenegem RC (1987) Judges, legislators and professors: chapters in European Legal History. Cambridge University Press, Cambridge

Van Schreeven WJ, Scribner RL (eds) (1973) Revolutionary Virginia: the road to independence, vol. I: forming thunderclouds and the first convention 1763-1774. University Press of Virginia, Charlottesville

Vetterli R, Bryner GC (1987) In search of the republic: public virtue and the roots of American Government. Rowman \& Littlefield, Totowa

Virgil (2005) Eclogues and Georgics. transl. by James Rhoades. Dover, Mineola

Willoweit D, Seif (=Müßig) U (2003) Europäische Verfassungsgeschichte. C.H. Beck, Munich

Wills G (1978) Inventing America: Jefferson's declaration of independence. Doubleday, Garden City

Wood GS (1969) The creation of the American Republic, 1776-1787. University of North Carolina Press, Chapel Hill

Wood GS (2015) The American Revolution: writings from the Pamphlet Debate 1773-1776. Library of America, New York

Open Access This chapter is licensed under the terms of the Creative Commons Attribution 4.0 International License (http://creativecommons.org/licenses/by/4.0/), which permits use, sharing, adaptation, distribution and reproduction in any medium or format, as long as you give appropriate credit to the original author(s) and the source, provide a link to the Creative Commons license and indicate if changes were made.

The images or other third party material in this chapter are included in the chapter's Creative Commons license, unless indicated otherwise in a credit line to the material. If material is not included in the chapter's Creative Commons license and your intended use is not permitted by statutory regulation or exceeds the permitted use, you will need to obtain permission directly from the copyright holder. 